\title{
Cross-border banking and the importance of parent banks' performance for subsidiaries' credit extensions: evidence derived from a newly constructed database
}

By Angeliki Zagorisiou

Supervised by

Professor Nikos Georgantzis

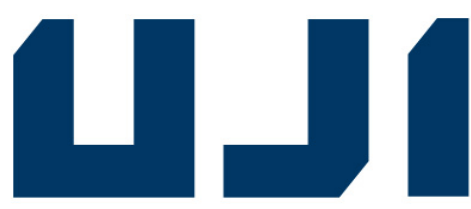

JUNE 2017

A thesis submitted in fulfillment of the requirements for the degree of Doctor of Philosophy 


\section{Table of Contents}

List of Tables ...................................................................................... 4

List of figures ...................................................................................... 4

Acknowledgements ...................................................................................... 5

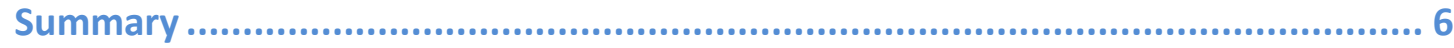

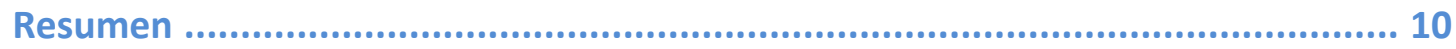

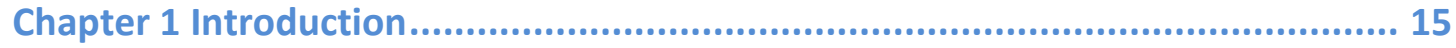

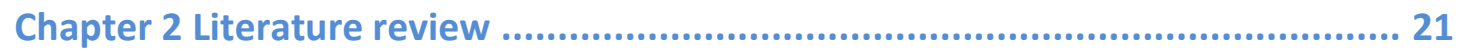

Chapter 3 Ownership Database and other Variables.......................................... 27

Chapter 4 Methodology ................................................................. 36

4.1. Dynamic credit growth with controls for ownership...................................................... 36

4.2. Crossed Random Effects Models ........................................................................................... 40

4.3. Dynamic credit growth with controls for parent's financials .......................................... 44

Chapter 5 Results.......................................................................... 49

5.1. Dynamic credit growth and ownership .......................................................................... 49

5.2. Second set of Models: controlling for the participation in a specific financial group and year effects..................................................................................................................... 57

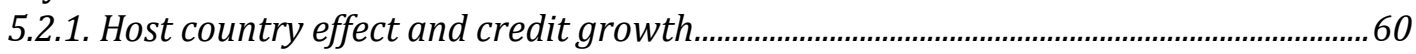

5.2.3. Financial group's country of origin as a determinant for credit growth.....................62

5.3. Parent bank fundamentals and credit growth .................................................................. 64

5.4. The effect of ownership before and after the crisis ........................................................ 73

5.5. Direct effects of excessive credit growth on future credit extensions ........................... 75

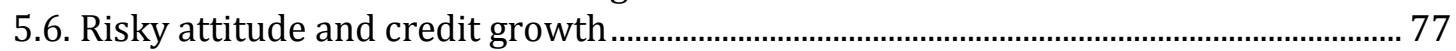

5.7. Credit growth of foreign banks and the Business cycle .................................................... 79

Chapter 6 Conclusions....................................................................... 83

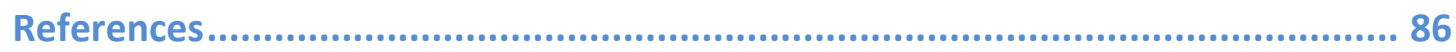

Appendices............................................................................... 90

A. Details on the construction of the sample..................................................................... 90

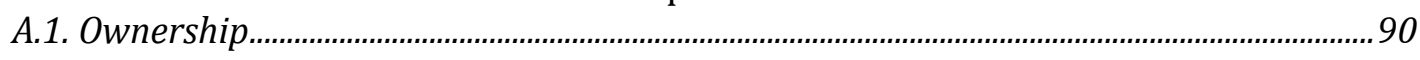

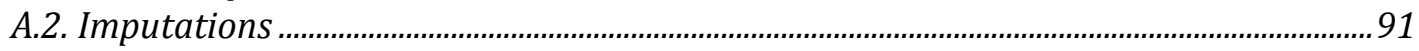

A.3. Duplication Issues.................................................................................................................. 92

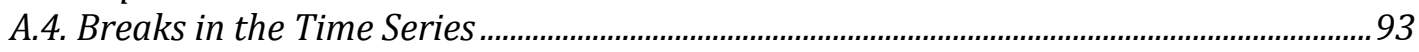

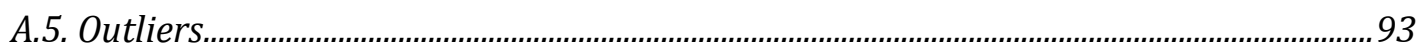

B. The Sample. Distribution of banks \& Aggregate Market shares ................................... 95

C. Variable Descriptions \& Sources, Correlation Tables and Structure of our Ownership

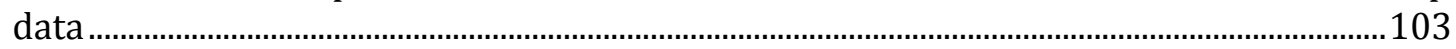

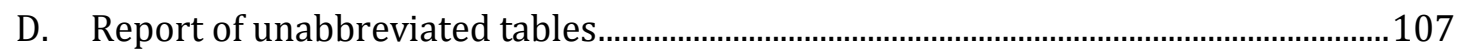




\section{List of Tables}

Table 3-1: Descriptive statistics of the variables. .32

Table 5-1: Factors affecting loan growth - estimations based on Equation (4.1) - including different definitions of foreign ownership

Table 5-2: Estimations based on Equation (4.1) - including the effect of mutually exclusive definitions of foreign ownership versus purely domestically owned banks.....

Table 5-3: Factors affecting loan growth - estimations based on Equation (4.1) - including the effect of being a member of a foreign financial group (subsidiary bank)

Table 5-4: Statistical test on differences in the level of characteristics between foreign owned banks and domestic banks.

Table 5-5: Estimations based on Equation (4.1) using the sub-sample of domestic banks (Model 1) and the sub-sample of financial group members (Model 2) .............................................................56

Table 5-6: Crossed Random Effects Models with controls for the parent effect .................................58

Table 5-7: Intra-class Correlations based on estimates of Equation (4.3) controlling for the parent effect

Table 5-8: Crossed Random Effects Models that control for the host country effect .............................61

Table 5-9 Intra-class Correlations based on estimates of Equation (4.3) controlling for the host country effect

Table 5-10: Crossed Random Effects Models, with controls for the home country and the parent effect

Table 5-11: Determinants of subsidiaries credit extensions - including parent banks' characteristics .65

Table 5-12: Determinants of subsidiaries credit extensions - including parent banks' fundamentals and controlling for year fixed effects and host country fixed effects

Table 5-13: Subsidiaries' credit growth - including parent banks' fundamentals, home country macro and excluding subsidiaries with parent banks operating with negative capital ratio .................... 70

Table 5-14: Subsidiaries' credit growth controlling for parent banks' fundamentals and excluding subsidiaries with assets exceeding $10 \%$ of financial group's total assets ...................................72

Table 5-15: Loan growth of members of foreign financial groups vis-à-vis domestic banks before and after crisis

Table 5-16: The effects of excessive credit growth at parent and subsidiary level.............................76

Table 5-17: Excessive risk taking a parent and subsidiary level ....................................................78

Table 5-18: Sensitivity to the Business Cycle ......................................................................................8 81

Table B-1: Distribution of banks by Country, Year and type of ownership .........................................95

Table B-2: Financial groups with subsidiaries operating in CESEE in 2000-2014........................... 101

Table C-1: Description and sources of the variables ................................................................. 103

Table C-2: Correlations of the variables calculated for the whole sample ........................................104

Table C-3: Correlations of the variables calculated only for the sub-sample of subsidiaries of foreign financial groups

Table D-1: Loan growth of members of foreign financial groups vis-à-vis domestic banks before and after crisis...

\section{List of figures}

Figure 3-1: Definitions of ownership and their impact on the database .............................................28

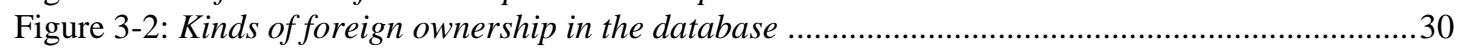

Figure A-1: Breaks in the time series and number of observations that were reconstructed ................93

Figure B-1: Aggregate market shares of foreign banks by country and year .......................................97

Figure B-2: Market share weighted aggregate credit growth of foreign banks vs domestic banks by country and year.....

Figure C-1: Structure of the data. ..106 


\section{Acknowledgements}

I would like to express my special appreciation and thanks to my supervisor, Prof.

Nikos Georgantzis for encouraging my research and allowing me to grow as a researcher.

I am indebted also to Luca Gattini, for his guidance and support throughout all the stages of this research. His expertise in the field of cross-border banking, was invaluable both for shaping the research questions and analyzing the findings.

I am especially grateful to the European Investment Bank Institute for the financial support through their Knowledge Program.

I am also thankful to María Aurora García Gallego for her immense help with the bureaucratic issues this procedure entailed.

I would also like to thank the Economics Department of the European Investment Bank for allowing me to use a number of commercial databases. Moreover, I am indebted to all the people working there for providing me the most supportive environment possible.

Finally, I thank Debora Revoltella, Joëlle Liebermann, Mark Allen, Annalisa Ferrando, Aron Gereben and Laurent Maurin for sharing their expertise at different stages and parts of this research and providing comments and suggestions. 


\section{Summary}

The systemic role of foreign banks in the CESEE region coupled with the turbulence in financial markets back in 2008, have given rise to the study at hand. Some years after the global crisis, it is a perfect moment to conduct an overarching analysis of the parent-subsidiary relationship and to examine how those banks behave at micro level.

Firstly, the study discerns between different types of foreign ownership and explores their propensity to extend credit vis-à-vis their domestic owned competitors. Secondly it focuses on banks, which are members of foreign financial groups and which constitute the vast majority of foreign owned banks with operations in the CESEE region. It investigates whether the parent level can explain any of the variation of subsidiaries' capability to extend credit. Thirdly it looks into the particular parent bank characteristics with an influence on subsidiaries credit growth. Fourthly it researches whether the ownership effect changes after the crisis. Finally, it investigates the effect of the business cycle on subsidiaries' credit extensions and how the business cycle of the home country of the parent bank matters.

A prerequisite for this investigation is the understanding of the actual ownership structure and changes. Banking sectors in the region are rather dynamic and characterized by entries, exits and changes of ownership, while major corporate restructuring has taken place at the parent level too. Therefore the present study is grounded in a unique and new database, which complements the empirical literature in several ways. It has both a wide geographical and sectorial coverage, while it has 
adopted a more thorough definition of foreign ownership that captures the cross border relationships at full extent. It identifies the ultimate owner of each subsidiary bank, instead of focusing only on the direct ownership. The final sample spans over the period 2000-2014 and includes 323 banks (domestic and subsidiary banks) operating in 18 countries of Central Eastern and Central Eastern Europe (CEESE) and 84 ultimate owner banks (parents).

The empirical exploration is divided into three logical steps. First, the study provides insights on the impact of foreign ownership on host countries' credit growth. Credit growth is modeled in a dynamic framework employing GMM estimation methodologies and accounting for ownership, individual bank characteristics as well as macroeconomic effects. Second, it is investigated the homogeneity of loan growth across subsidiaries belonging to the same international financial group (parent), operating in different markets. In this step a Crossed Random Effects Model is employed. By doing so, it is proved that there is an omitted common effect across the subsidiaries. Therefore the empirical models employed above, can produce consistent estimates of the credit growth of subsidiaries only if controls are added for those factors. Which leads to the third step. In the dynamic credit growth model are added further parent bank variables/controls as well as parent related such as the country of origin of the parent and the macroeconomic conditions in the home country.

Estimation results indicate that all types of foreign participation in the ownership structure are crucial to the performance of the subsidiary. However, members of foreign financial groups are bearing the largest influence and most significant one. 
Given that they constitute the largest category of foreign owners, it is crucial to investigate further their behavior. Subsidiaries' credit behavior cannot be viewed in isolation. To the contrary, it needs to be framed into the operating landscape, which includes the linkages to foreign entities and their economies.

Subsidiaries' profitability has been found significant only rarely. Therefore, subsidiaries do not fund their growth through their own profits. This indicates a longer-term expansion strategy of parents in the region, whereby current profitability at the domestic level is a secondary parameter. Parents' asset quality (loan impairment charges) is a relevant determinant of credit growth at subsidiary level. Loan impairment charges are also at subsidiary level significant. Loan impairments are the result of the project screening intelligence at consolidated level. The global financial crisis determined losses for banks and a deterioration of their loan portfolio. The measure of loan impairments and their effect on credit growth capture intrinsic characteristics of parents such as their ability to manage their portfolios and choose to finance profitable projects. Finally, a peer group analysis unveils that risky behaviors at the parent bank level jeopardize future credit extensions at the subsidiary level. Specifically, excessive credit expansion and reduction of economic capital ratios lead to a decline in subsidiaries' lending capacity in three years' time.

Overall, the presence of foreign banks in the CESEE region is judged as beneficial. Parent banks originated from flourishing economies benefit the host countries, through further extensions of credit by their subsidiaries. Indeed, they have contributed to a contraction of credit after the global financial crisis. Yet, their 
reaction was less pronounced compared with the contraction exercised by domestic banks. 


\section{Resumen}

El papel sistémico de los bancos extranjeros en la región de Centro-Europa y Europa Oriental (CESEE), junto con la turbulencia de los mercados financieros en 2008, han dado lugar al estudio actual. Algunos años después de la crisis global, es un momento perfecto para llevar a cabo un análisis global de la relación banco matriz-filial y para examinar cómo se comportan esos bancos a nivel microeconómico.

En primer lugar, el estudio discierne entre los diferentes tipos de propiedad extranjera y explora su propensión a extender el crédito frente a sus competidores nacionales. En segundo lugar, se centra en los bancos, que son miembros de grupos financieros extranjeros y que constituyen la gran mayoría de los bancos de propiedad extranjera con operaciones en la región CESEE. Investigamos si el papel de los bancos principales puede explicar alguna parte de la variación de la capacidad de sus filiales para extender el crédito. En tercer lugar, se examinan las características particulares de los bancos principales, lo que influye en el crecimiento del crédito de las filiales. En cuarto lugar, investigamos si el efecto de propiedad cambia después de la crisis. Por último, se investiga el efecto del ciclo económico sobre las ampliaciones de crédito de las filiales y cómo afecta el ciclo económico del país de origen del banco matriz.

Un requisito previo para esta investigación es la comprensión de la estructura de propiedad real y los cambios. Los sectores bancarios de la región son bastante 
dinámicos y se caracterizan por las entradas, las salidas y los cambios de propiedad, mientras que la reestructuración de las grandes empresas también ha tenido lugar en la matriz. Por lo tanto, el presente estudio se basa en una base de datos única y nueva, que complementa la literatura empírica de varias maneras. Permite una amplia cobertura geográfica y sectorial, mientras adopta una definición más completa de la propiedad extranjera que capta las relaciones transfronterizas en toda su extensión. Identificamos al propietario final de cada banco subsidiario, en lugar de centrarnos sólo en la propiedad directa. La muestra final abarca el período 2000-2014 e incluye 323 bancos (bancos nacionales y filiales) que operan en 18 países de Europa central y oriental y 84 bancos propietarios (matriz).

La exploración empírica se divide en tres pasos lógicos. En primer lugar, el estudio proporciona información sobre el impacto de la propiedad extranjera sobre el crecimiento crediticio de los países anfitriones. El crecimiento del crédito se modela en un marco dinámico que emplea metodologías de estimación de GMM y que explica la propiedad, las características individuales de los bancos y los efectos macroeconómicos. En segundo lugar, se investiga la homogeneidad del crecimiento de los préstamos entre las filiales pertenecientes al mismo grupo financiero internacional (matriz), que operan en diferentes mercados. En este paso se emplea un modelo de efectos aleatorios cruzados. Al hacerlo, se demuestra que existe un efecto común omitido entre las filiales. Por lo tanto, los modelos empíricos empleados anteriormente, pueden producir estimaciones consistentes del crecimiento del crédito de las subsidiarias sólo si se agregan controles para esos factores. Lo que lleva al tercer paso. En el modelo dinámico de crecimiento del crédito se añaden otras variables de control del banco matriz, así como relacionados con los padres, tales 
como el país de origen del padre y las condiciones macroeconómicas en el país de origen.

Los resultados de la estimación indican que todos los tipos de participación extranjera en la estructura de propiedad son cruciales para el desempeño de la subsidiaria. Sin embargo, los miembros de los grupos financieros extranjeros tienen la mayor influencia y la más significativa.

Dado que constituyen la categoría más grande de propietarios extranjeros, es crucial investigar más a fondo su comportamiento. El comportamiento crediticio de las filiales no puede considerarse aisladamente. Por el contrario, necesita ser enmarcada en el panorama operativo, que incluye los vínculos con entidades extranjeras y sus economías.

La rentabilidad de las filiales se ha encontrado significativa solamente en algunos casos. Por lo tanto, las filiales no financian su crecimiento con sus propios beneficios. Esto indica una estrategia de expansión a largo plazo de los padres en la región, por lo que la rentabilidad actual a nivel doméstico es un parámetro secundario. La calidad de los activos de los padres (cargos por deterioro del crédito) es un determinante relevante del crecimiento del crédito a nivel subsidiario. Las cargas por deterioro de préstamos también son significativas a nivel subsidiario. Los impedimentos del préstamo son el resultado de la inteligencia de tamizaje del proyecto a nivel consolidado. La crisis financiera mundial determinó pérdidas para los bancos y un deterioro de su cartera de préstamos. La medida de los deterioros de préstamos y su efecto sobre el crecimiento del crédito capturan las características intrínsecas de los 
padres, como su capacidad para administrar sus carteras y optan por financiar proyectos rentables. Por último, un análisis de grupos de pares revela que los comportamientos arriesgados en el nivel del banco padre ponen en peligro futuras extensiones de crédito a nivel subsidiario. En concreto, la expansión excesiva del crédito y la reducción de los coeficientes de capital económico llevan a una disminución de la capacidad crediticia de las filiales dentro de tres años.

En general, la presencia de bancos extranjeros en la región CESEE se confirma como un factor beneficioso. Los bancos-matriz se originan a partir de economías en auge y benefician a los países de acogida, a través de grandes extensiones de crédito por parte de sus filiales. De hecho, han contribuido a una contracción del crédito tras la crisis financiera global. Sin embargo, su reacción fue menos pronunciada en comparación con la contracción ejercida por los bancos nacionales. 



\section{Chapter 1 Introduction}

Foreign owned banks fostered convergence and economic growth in Central Southern Eastern Europe (CESEE). They contributed to raise the living standards and supported increasing investment levels. During the period 1998-2005, foreign banks issued $85 \%$ of new credit in New Member States ${ }^{1}$ (Sirtaine and Skamnelos, 2007). Today the share of foreign ownership in the banking sector is exceptionally high, making most subsidiary banks systemically important at local level. Moreover, the existence of internal capital markets within international banking groups is a fundamental vehicle to spur growth throughout the network as well as to possibly transmit financial weaknesses. Recently the global financial crisis imposed severe capital and liquidity constraints to the parents of branches/subsidiaries operating in the CESEE region. This has possibly contributed to the transmission of shocks from home to host countries, thus threatening financial stability and requiring safeguards. For example, the Vienna Initiative, a public-private coordination mechanism, was

\footnotetext{
${ }^{1}$ Estonia, Latvia, Lithuania, Hungary, Czech Republic, Poland, Slovakia, Slovenia, Bulgaria, Croatia, Romania
} 
established to avoid disruptive behaviors in five economies of emerging Europe at the early stages of the financial crisis. Several years after the breakout of the global crisis it is a perfect moment to form a thorough understanding of the parent/subsidiary relationship and its functioning in a multi-years perspective starting from early 2000.

Several studies have investigated the role of foreign owned banks on host economies performance and banking sector financial stability. To do so, numerous approaches and methodologies have been employed. A stream of research connects firm level data with bank characteristics and controls for ownership effects during a very short time period. Another strand of literature uses either highly aggregated data or bank level data (Sirtaine and Skamnelos, 2007) to examine the lending behavior of banks. For example, Cetorelli and Goldberg (2010) investigated the transmission of the global financial crisis across borders. Their analysis is based on highly aggregated data, sourced from the Bank for International Settlements' (BIS) Consolidated International Banking Statistics.

A third approach employs bank level data and examines the effect of ownership on subsidiaries' lending behavior over an extended period of time. Cull and Martinez Peria (2013) examined the impact of bank ownership on credit growth in Latin America and Eastern Europe immediately before and during the 2008/2009 crisis. Dinger (2009) builds on a database structured along a relatively extended time period (1994-2004), while focusing on ten CEE countries. On aggregate the study shows that a high degree of foreign bank penetration - via subsidiaries - smooths aggregate liquidity problems. De Haas and Van Lelyveld (2006) sample the CEE region for the period 1993-2000. It finds that foreign banks provide more stable lending than 
domestic banks. Foreign owned banks are more sensitive to host country's growth than domestic banks. The authors attribute this evidence to the emergence of internal capital markets within financial conglomerates. De Haas and Van Lelyveld (2010) develops the previous analysis employing a worldwide sample of 45 multinational for the period 1991-2004. De Haas and Van Lelyveld (2014) includes also the period of the global financial crisis. This paper employs bank level data covering a sample of large 48 multinational banks with global operations for the period 1992-2009. It finds that multinational bank subsidiaries during the credit crunch cut down credit more than the counterfactual they constructed - i.e. a sample of domestic banks. Allen et al. (2015) studies the effect of ownership in 11 CEE countries over the period 19942010, comparing foreign owned banks (subsidiaries) to domestic owned banks. Jeon et al. (2013) finds that subsidiaries' lending behavior is strongly influenced by their parents' financial condition. This was found particularly strong in Central and Eastern Europe. The paper employs a worldwide sample of 68 large multinational banks with subsidiaries in emerging economies for the period 1994-2008.

Current research is enshrined in the third stream of literature. Given foreign banks systemic importance in the CESEE region, it is necessary to revisit their role for local financial stability and to examine how those banks behave at micro level. Therefore, it is tested the propensity to extend credit of foreign owned banks (i.e. subsidiaries) visà-vis their domestic owned competitors. Moreover, there are investigated the key subsidiaries' and parents' characteristics influencing credit extensions. A focal point of the analysis is the health of banks (both parent and subsidiary health). For example, thinly capitalized banks tend to respond to moral hazard incentives and undertake increased portfolio risk, thus showing high NPL ratios the following years (Berger 
and De Young, 1997). As a result high NPLs may constraint the ability of banks to lend even more so when combined with a weak economic capital and asset position.

The current study addresses a set of key interrelated questions. Did subsidiaries extend credit more than domestic banks? And was this effect the same before and after the crisis? Have parents' characteristics had an influence on subsidiaries' capability to extend credit? Have health and risk-taking attitude of parent banks impacted on subsidiaries credit growth? Finally, what is the effect of the business cycle on subsidiaries' credit extensions and how the business cycle of the home country of the parent bank matters?

A prerequisite for this investigation is the understanding of the actual ownership structure and changes. Many subsidiaries operating across different countries in the region share the same parent. Moreover, banking sectors in the region are rather dynamic and characterized by entries, exits and changes of ownership. After the first privatization wave, foreign banks kept entering the market, thus creating new banks (greenfields). Another phase in the development of the CESEE banking sector has seen takeovers at subsidiary level and major corporate restructuring at the parent level.

A necessary condition to conduct the analysis is the construction of a suitable database. Indeed, a unique and new database was constructed which complements and enhances the empirical literature in different ways. First, it combines a very wide geographical coverage of the region (i.e. 18 CEESE countries over 14 years). Second, 
it has adopted a more thorough definition of foreign ownership. It identifies the ultimate owner of each subsidiary bank, instead of focusing only on the direct ownership as done in previous studies. This definition of ownership helps capturing the cross border relationships at full extent over time. Third, it is of wider sectorial coverage, since the ownership of all banks operating in the CESEE region has been looked into; whilst earlier studies examine the behavior of some major multinational banks operating in the same perimeter.

The analysis examines credit growth in a dynamic setting and uses controls for ownership. It distinguishes between domestic banks and several types of foreign ownership. The first result indicates that subsidiaries owned by foreign financial groups provide an extra boost to credit growth at the domestic level. Before scrutinizing the nexus between parent bank characteristics and subsidiaries' credit extensions, the study pins down empirically why we must control for parent level features. To my knowledge, this paper is the first to do so in this stream of literature. A static crossed random effects model is employed in order to measure the similarity between subsidiaries belonging to the same group. Subsidiaries that share the same parent and operate during the same year exhibit exceptionally similar patterns, when it comes to credit extensions. The finding of this stage of analysis is that banks operating across different countries in the region are very much similar in the way they extend credit if they belong to the same parent bank.

These results guide the study to the next stage. A dynamic credit growth model is estimated across the sub-sample of subsidiaries owned by foreign financial groups, controlling systematically for subsidiary and parent banks' characteristics as well as 
home and host macro factors. Parent bank health in terms of asset quality is one of the most important and consistent predictors of subsidiaries credit growth. Also past profitability at consolidated level is an important determinant of subsidiary's credit growth. Therefore, banks manage their profit and losses at consolidated level; and consequently it is at consolidated level that one expects to detect a risky behavior when extending credit at subsidiary level.

The paper is structured as follows. Section 2 reviews the relevant literature. Section 3 describes our database, its construction and some statistical properties of the employed variables. Section 4 presents the employed empirical approach and the estimation methodologies. Section 5 reports and discusses the results. By doing so, it explores further types of risky behaviors both at subsidiary and at parent level. Section 6 concludes. 


\section{Chapter 2 \\ Literature review}

The global financial crisis has triggered research concerning the role of foreign banks in financial stability. A stream of research connects firm level data with bank characteristics and controls for ownership effects during a very short time period. Another strand of literature uses either highly aggregated data or bank level data (Sirtaine \& Skamnelos, 2007) to examine the lending behavior of banks. A third strand of research employs bank level data and examines the effect of ownership on lending behavior over an extended period of time.

The first stream of research employs survey data sourced from SMEs. For example, Ongena et al. (2013) match banks in Eastern Europe and Central Asia with a sample of medium and small firms (SMEs). It examines the lending behavior for a short time span (2007-2009) around the event of the global financial crisis. It finds that foreign banks and wholesale-funded domestic banks reduced credit more heavily than their competitors. Popov and Udell (2012) focuses on Eastern European countries and compares two years (2005 and 2008). This paper shows that a stronger presence of foreign intermediaries induces either a higher probability of loan applications being denied or firms are deterred from applying. Moreover, parent bank "health" matters 
for credit extensions. The authors find that financially distressed parent banks increase the probability of local firms being financially constrained.

Cetorelli and Goldberg (2010) investigated the transmission of the global financial crisis across borders. Their analysis is based on highly aggregated data, sourced from the Bank for International Settlements' (BIS) Consolidated International Banking Statistics. It compares two short time periods, before and after the global crisis ${ }^{2}$. This paper finds that credit supply in emerging markets was affected both through contraction in exposures of foreign-owned banks and through domestic banks' retreat due to the breakdown of interbank lending.

Cull and Martinez Peria (2013) examined the impact of bank ownership on credit growth in Latin America and Eastern Europe immediately before and during the 2008/2009 crisis. Foreign banks in Eastern Europe fueled loan growth prior to the crisis and contracted their loans at a faster pace than domestic banks during the crisis. The econometric model they employ enables them to control simultaneously for parent bank characteristics; specifically parent equity ratio, parent liquidity and parent profitability were found to affect credit growth of subsidiaries'.

Dinger (2009) builds on a database structured along a relatively extended time period (1994-2004) while focusing on ten CEE countries. The paper starts with the consideration that liquidity flows (including cross border flows) are a fundamental feature ensuring stability of the banking sector and therefore aggregate financial stability. Foreign banks' liquidity behavior differs significantly from that of domestic

\footnotetext{
${ }^{2}$ The period between 2006:Q2 and 2007:Q2 is compared to the crisis period of 2008:Q3-2009:Q2
} 
banks in normal times. For example, foreign owned subsidiaries hold less liquid reserves. However, they increase them during times of aggregate liquidity shortages in the host country. On aggregate, the study shows that a high degree of foreign bank penetration - via subsidiaries - smoothens aggregate liquidity problems. Foreign banks have access to a diversified set of international sources of liquidity. Therefore, they are less concerned to withhold assets during tranquil times. In addition, they can also increase their volumes in turbulent times.

De Haas and Van Lelyveld (2006) sample the CEE region for the period 1993-2000. It finds that foreign banks provide more stable lending than domestic banks. Foreign owned banks are more sensitive to host country's growth than domestic banks. The authors attribute this evidence to the emergence of internal capital markets within financial conglomerates. For example, banking groups tend to reallocate more capital to the host countries that have a higher growth. The authors find that subsidiary banks (either acquired or newly established) play a crucial role during crises times. They continue to expand credit contrary to domestic banks that contract their credit. In addition, lower GDP growth in the home country triggers higher credit growth in the host country. This finding suggests that international banking group's substitute compensate the poor home market performance via a more pronounced penetration in the host markets. However, a declining parent banks' financial health forces a slowdown of subsidiaries' credit growth, primarily when the subsidiary bank is established by the parent and not acquired.

De Haas and Van Lelyveld (2010) confirms the findings above employing a worldwide sample of 45 multinational for the period 1991-2004. In this paper more 
parent bank characteristics are added. Parent bank health (loan loss provisions to net interest income), profitability, liquidity and interest margins play a more prominent role in the case of greenfield, but are proven relevant for all types of subsidiaries.

De Haas and Van Lelyveld (2014) includes also the period of the global financial crisis. This paper employs bank level data covering a sample of large 48 multinational banks with global operations for the period 1992-2009. It finds that multinational bank subsidiaries during the credit crunch cut down credit more than the counterfactual they constructed - i.e. a sample of domestic banks. Internal capital markets seem to operate in all directions. Multinational banks allocate resources to that part of the group that is hit by a financial shock. If that shock concerns the core of the group, then funding from the periphery can flow to the core or at least parental support ceases to exist.

Allen et al. (2015) studies the effect of ownership in 11 CEE countries over the period 1994-2010. It compares foreign owned banks (subsidiaries) to domestic owned banks. During tranquil periods ownership structure and parent financial characteristics are not important for local credit growth. However these factors are significant during home and host crisis periods. During home country crises, subsidiaries owned by profitable and solvent parents reduce their lending growth in the host economies. On the other hand, large, profitable and solvent parent banks favor credit growth of their subsidiaries during a host country crisis.

Jeon et al. (2013) finds that subsidiaries' lending behavior is strongly influenced by their parents' financial condition. This paper employs a worldwide sample of 68 large 
multinational banks with subsidiaries in emerging economies for the period 19942008. It finds that internal capital markets transmit both favorable and adverse shocks. They capture this mechanism exploiting subsidiaries' reliance on their own internal funds. When parents enjoy abundant cash flows, subsidiaries depend less on their own funds to expand credit growth. This mechanism was found particularly strong in Central and Eastern Europe. In addition also parent liquidity conditions play a role. 



\section{Chapter 3 \\ Ownership \\ Database and other \\ Variables}

The empirical analysis is based on a CEESE focused sample of 323 banks operating in 18 countries $^{3}$. Banking theory would predict that each individual bank extents credit on the grounds of its own financial characteristics and macroeconomic conditions. However, a good share of these banks is foreign owned (see Appendix Figure B-1 for the evolution over time of the domestic and foreign owned banks market shares). Therefore, the aim is also to control for the possibility that foreign owned banks are able to extent credit differently than domestic banks because the former can leverage on a financial group organization. For example, financial groups can manage centralized treasury operations thus generating internal capital market to allocate capital across their subsidiary network irrespectively of the subsidiary characteristics and domestic (host) economic conditions. Therefore, it is also included in the database a set of relevant statistics for the ultimate owner banks (parents). Their

\footnotetext{
${ }^{3}$ Albania, Armenia, Bosnia Herzegovina, Bulgaria, Czech Republic, Estonia, Hungary, Croatia, Kosovo, Lithuania, Latvia, Montenegro, FYROM, Poland, Romania, Serbia, Slovak Republic and Slovenia.
} 
total number is 87 . The constructed database covers the period 2000-2014. Table B-1 in the Appendix reports the details on the number of banks per country, per category (foreign or domestic) and per year of operation. To avoid double counting the merger history of each parent and subsidiary bank has been carefully examined. Much attention has also been paid on the selection of the accounting regime. Details on the selection and data cleaning process are reported in the Appendix (A).

Figure 3-1: Definitions of ownership and their impact on the database

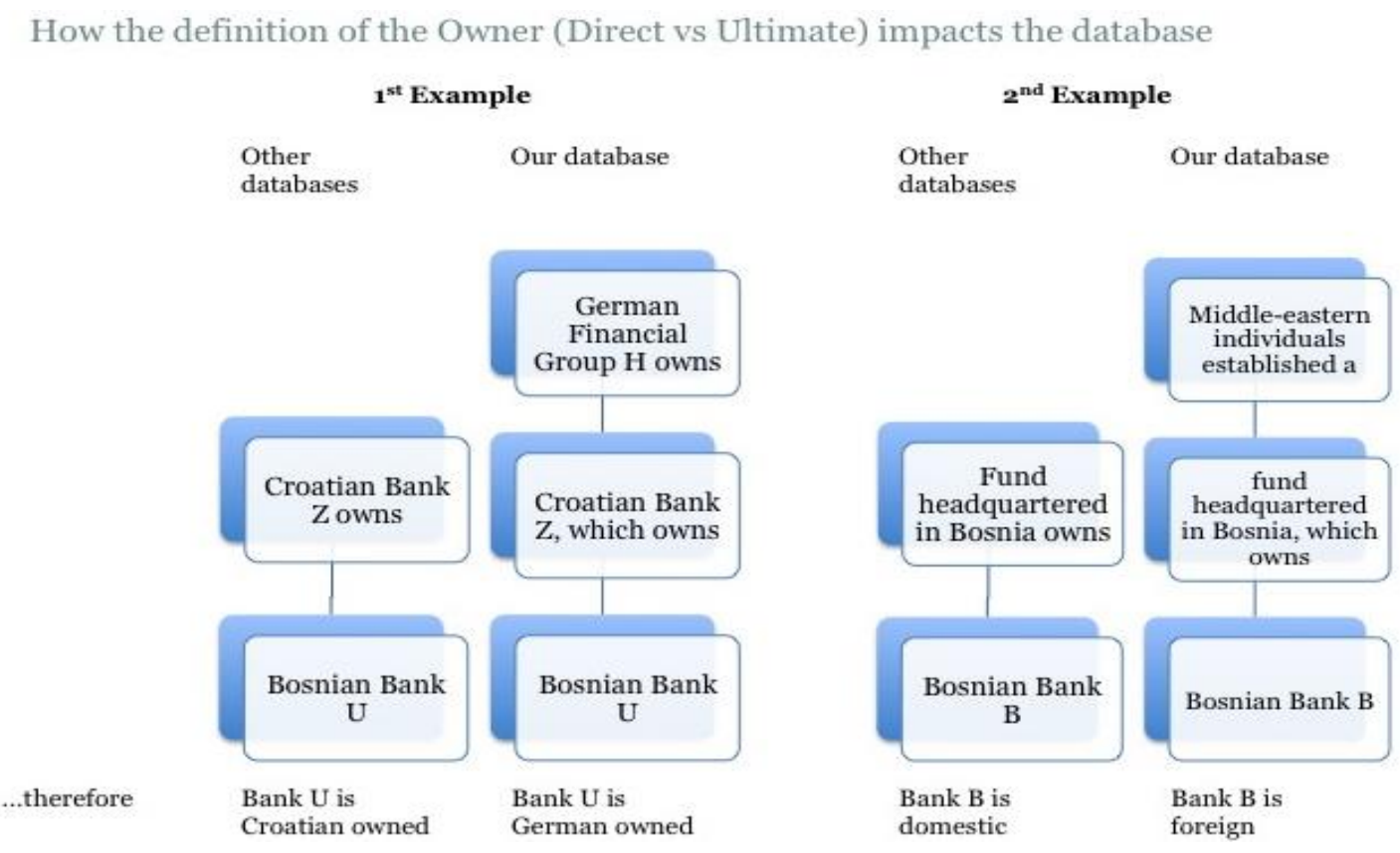

As a result, an original and unique dataset has been constructed, which includes time series information on banks' balance sheets as well as variables capturing the time varying nature of subsidiaries' ownership structure. The initial and baseline source was Bureau van Dijk's Bankscope. However it has not been adequate and a a wide variety of additional sources ${ }^{4}$ served to complement and cross-check the database: Amadeus by Bureau van Dijk, published financial statements, S\&P IQ capital,

\footnotetext{
${ }^{4}$ In each case the reliability of the source available is assessed and determines the number of additional sources needed in order to cross check the data. For example, this study always considers audited financial statements to be superior to information sourced from commercial databases.
} 
Bloomberg, Central bank reports, Ministries' reports, stock exchanges and news. A bank is defined as foreign owned if foreigners hold over $49.9 \%$ of the shares as done in previous studies. To the contrary, this study introduces a novelty in the definition of ownership, which enhances the definition normally utilized in previous studies ${ }^{5}$ Specifically, it identified the ultimate owner of each subsidiary bank, instead of focusing only on the direct owner. By doing so, it also defined the nationality of the ultimate owners of the parent companies and not only their legal headquarters. The ultimate ownership definition should allow better capturing cross border economic and financial relationships among owners and owned entities. On the other hand, the shortcut of identifying direct ownership may not be enough to reach this goal. To better gauge the difference between ultimate and direct ownership, below is presented a randomly selected example (Figure 3-1) of two banks operating in BosniaHerzegovina. It exemplifies the effect of applying the ultimate ownership definition and compares the results with another dataset ${ }^{6}$ publicly available. As it can be easily grasped from (Figure 3-1 the ultimate owner definition identifies more precisely the final owner of an already detected foreign owned bank (example 1) as well as it contributes to actually detect a foreign owner otherwise defined as domestic (example 2).

Table C-2 in the Appendix reports the correlations across our whole sample and Table C-3 presents the correlations among the variables that concern only the sub-sample of

\footnotetext{
${ }^{5}$ De Haas and Van Lelyveld (2006), Claessens et al (2008), Jeon et al (2013), Allen et al. (2015)

${ }^{6}$ The database constructed by Claessens et al. (2008) has been made partially available by the National bank of Netherlands. It reveals the nationality of the direct owner but not the name of the identified owner. The examples have been drawn randomly and are a comparison of the current data and those documented in previous literature. It should be noted also that previous literature follows the definition adopted by Claessens et al. (2008).
} 
subsidiaries of multinational financial groups. This serves as a basis to start our empirical investigation.

Figure 3-2: Kinds of foreign ownership in the database

\section{Dataset}

The different kinds of foreign ownership in our database

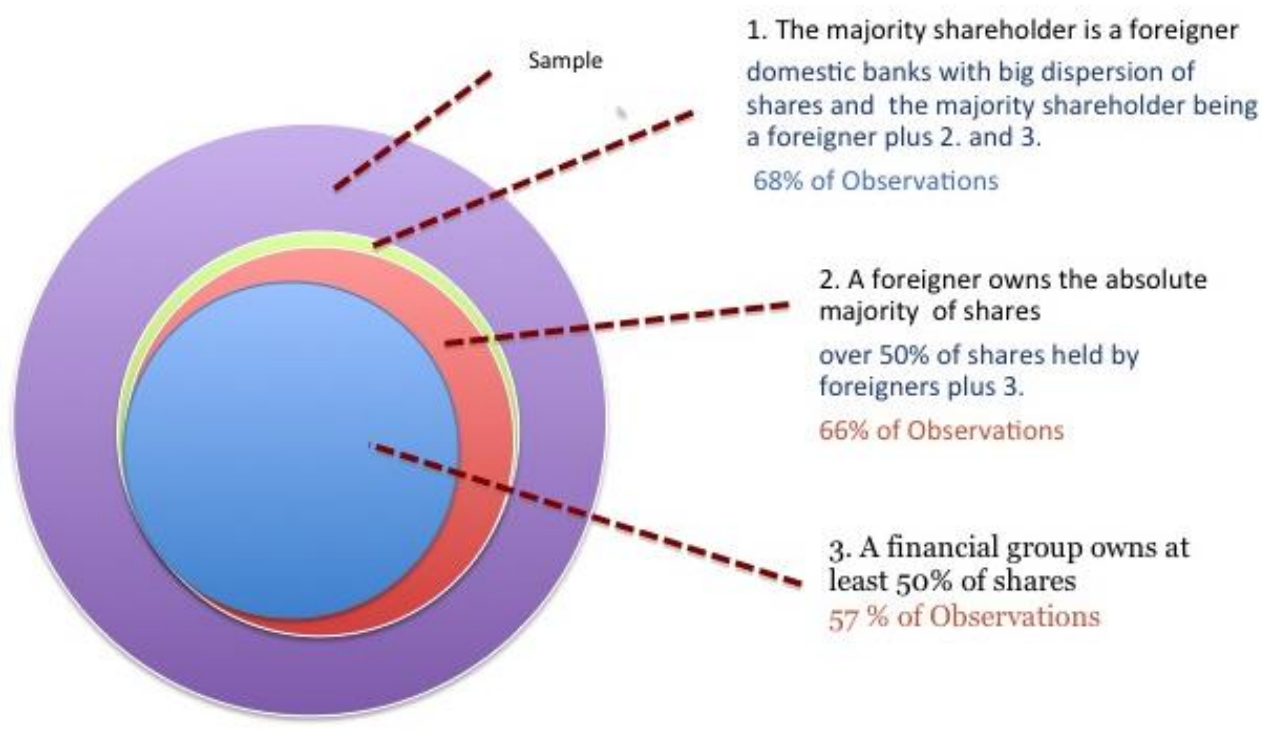

In the sample foreign owned banks constitute $66 \%$ of the total observations (Figure 3-2). There are two more categories of foreign ownership: (i) banks with a foreign entity/ person as major shareholder; (ii) banks owned by a foreign financial group (with owned shares above $49.9 \%$ ). The former category represents $68 \%$ of the total observation and it is the most ample as it also includes all foreign owned banks. The latter category is smaller. It represents $57 \%$ of total observations and it is a subsample of all foreign owned banks. A good part of the current analysis focuses on this last category - as most of the literature does - for a number of reasons stated in section Chapter 0. Another reason is that a researcher can leverage data from financial 
statements of financial groups, while one cannot determine the financial balance sheet individuals, for instance.

Table 3-1 reports the list of variables included in our analysis and their descriptive statistics. The dependent variable is credit growth and the variables are collected on an annual frequency. As in previous literature, individual bank characteristics are included such as capital ratio, liquidity, size, profitability, deposit ratio and asset quality.

Capital is defined as economic capital or the ratio of equity to total assets. Liquidity is the ratio of liquid assets to total assets. Well-capitalized and liquid banks are expected to extend credit more easily. On the other hand, maintaining an exceptionally high level of capital and too high liquid assets retentions may also reflect an elevated risk aversion thus contributing to slow the expansion of credit (De Haas and Van Lelyveld, 2006).

Size is included as the natural logarithm of total assets. Large banks have better access to capital markets and tend to raise less expensive capital. This may increase their profit margins and improves their lending position (Brissimis \& Delis, 2009). However, a large bank may have lower incentives to increase further its market share or its balance sheet needs to grow less robustly to achieve a substantial amount of new lending given the ample size of the existing portfolio. Therefore, its average credit growth can be smaller than the average credit of a new, and relatively small, market player. 
Profitability is measured as return on assets. In general, high profitability should create incentives to expand activities thus increase credit. However, some banks with a highly profitable strategy may opt for a "quite life" approach and avoid aggressive expansions of credit. Moreover incumbents may have cherry picked their clients when competition was lower in the past, securing higher profitability. However, those opportunities may be less and less when new entrants appear on the market thus even highly profitable banks may extend credit at a slower pace.

Table 3-1: Descriptive statistics of the variables

Subsidiary \& Host Country charachteristics

\begin{tabular}{|c|c|c|c|c|c|c|}
\hline Variable & Description & Obs & Mean & $\begin{array}{l}\text { Std. } \\
\text { Dev. }\end{array}$ & Min & Max \\
\hline Credit & The natural logarithm of loans & 3555 & 13.0 & 2.0 & 2.0 & 17.7 \\
\hline Economic Capital ratio & Equity to assets, $\%$ & 3572 & 13.7 & 10.0 & 0.0 & 100.0 \\
\hline Liquidity ratio & Liquid assets to total assets, $\%$ & 3569 & 30.0 & 19.2 & 0.0 & 99.9 \\
\hline Size & The logarithm of assets & 3572 & 13.7 & 1.8 & 8.4 & 18.1 \\
\hline Profitability & Return on assets, $\%$ & 3561 & 0.8 & 2.8 & -33.6 & 52.7 \\
\hline Deposit ratio & $\begin{array}{l}\text { Customer deposits to total } \\
\text { funding, } \%\end{array}$ & 3540 & 74.5 & 22.1 & 0.0 & 100.0 \\
\hline Loan Impairments & $\begin{array}{l}\text { Loan impairment charges to } \\
\text { loans, } \%\end{array}$ & 3354 & 7.5 & 18.9 & -76.9 & 100.0 \\
\hline Real GDP growth & & 3572 & 3.4 & 4.1 & -16.0 & 22.9 \\
\hline Inflation rate & & 3572 & 5.5 & 8.9 & -2.4 & 95.0 \\
\hline Interest rate & & 3572 & 8.2 & 5.8 & 0.2 & 45.6 \\
\hline \multicolumn{7}{|c|}{ Parent \& Home country charachteristics } \\
\hline Variable & Description & Obs & Mean & $\begin{array}{l}\text { Std. } \\
\text { Dev. }\end{array}$ & Min & Max \\
\hline Parent Profiability & Return on assets, $\%$ & 2032 & 0.4 & 1.7 & -13.5 & 19.9 \\
\hline Paren Liquidity & Liquid assets to total assets, $\%$ & 2031 & 21.8 & 11.5 & 0.4 & 83.7 \\
\hline & Equity to assets, \% & 2032 & 6.0 & 3.9 & -5.5 & 82.4 \\
\hline Parent loan impairments & $\begin{array}{l}\text { Loan impairment charges to } \\
\text { loans, } \%\end{array}$ & 1991 & 1.2 & 1.5 & -6.3 & 21.2 \\
\hline $\begin{array}{l}\text { Home country: Real GDP } \\
\text { growth }\end{array}$ & & 2041 & 1.3 & 3.0 & -16.4 & 11.1 \\
\hline Home country: Inflation rate & & 2042 & 2.8 & 3.6 & -1.3 & 54.9 \\
\hline
\end{tabular}

To account for the deposit rate, the ratio of customer deposits to total funding is included. A high deposit rate provides a stable funding source for banks thus a 
support to credit growth. It is also a signal that banks enjoy the trust of consumers. On the other hand a high deposit rate may indicate that banks have difficulty in raising funds from the interbank markets, therefore they cannot easily substitute their funding sources and leverage on market opportunities when the circumstances require doing so.

As a proxy for asset quality is used the ratio of loan impairment charges to average gross loans. Non-performing loan figures were avoided for two reasons. First, there is no apparent consensus among regulators of the whole set countries under scrutiny on which loans are categorized as NPLs and this obviously affects also write-offs. Moreover, write-offs are the outcome of decisions taken even a decade or more before the actual write-off action. Therefore, this does not allow us to draw direct inferences on the credit expansion policy of current owners. Second, the missing values of the NPLs and write-off variables are very much elevated for banks and countries under scrutiny.

Impairments are losses incurred if there is objective evidence that impairment of a loan or portfolio of loans has occurred. These are flow variables. For example, the loan amount recorded in the loan book may be above the present value of the estimated future cash flows of the financed asset. As a result this difference must be recognized as expense in the income statement. The present value of the estimated future cash flows can fall below the book value due to several events, which however are not necessarily enough to render a loan non-performing. For example the obligor might be in severe financial difficulty (realized losses, cancelled purchased agreements from customers, inventory increase, deterioration of profitability), without having defaulted on his loan payments yet. Until 2014 impairment charges referred 
only to material events and would strictly exclude future events. As a result, impairment charges represent asset quality deterioration at its very early stage. Comparisons across a single market allow someone to speculate on a bank's level of portfolio diversification and assess its project pre-screening intelligence. This measure is preferred to loan loss provisions because the latter refers to future events that may cause impairments. Therefore, its nature could be speculative and allow management to shift provisions from one year to another depending on the profitability of the bank in a given year thus using provisions as a tool to reduce the tax burden. Similarly, banks might provision less after a year sparked with low profitability to inflate earnings.

Last but least, the study includes controls for macroeconomic and financial factors of host and home countries. Real GDP growth is employed, interest rates and inflation rate. Real GDP growth controls for aggregate economic growth and captures demand side effects. It is expected to have a positive impact on credit growth. The inflation rate is measured as the year-to-year change of the consumer price index. A rise in prices is expected to increase demand for loans and also inflate the value of banks' loan portfolios. However, the inflation rate may also reflect instability thus forcing banks to ration credit (Boyd, Levine, \& Smith, 2001). Therefore, the effect of this variable can run in both directions. Finally, controls for interest rates are included. High interest rates create an incentive for banks to lend more while they reduce clients' demand for credit. As a result, also the sign of this variable can be positive or negative. 



\section{Chapter 4}

\section{Methodology}

\subsection{Dynamic credit growth with controls for ownership}

In order to gain insight into the impact of ultimate ownership - discriminating between foreign and domestic owned banks $-\mathrm{a}$ first set of regressions is run. The effect of ownership is captured with a dummy variable. Following De Haas \& Lelyveld (2006), Cull \& Martinez (2013) and Bertay et al (2015), the study models credit growth as a function of ownership and individual bank characteristics. It also controls for macroeconomic effects on credit growth (as in De Haas \& Lelyveld, 2006 and Bertay et al, 2015). To account for a possible persistence of credit growth a dynamic framework is used (Bertay, Demirgüç-Kunt, \& Huizinga, 2015). Thus, the following model is estimated:

$$
\Delta \mathrm{L}_{\mathrm{i}, \mathrm{t}}=\alpha_{0}+\alpha_{1} \Delta \mathrm{L}_{\mathrm{i}, \mathrm{t}-1}+\sum_{k=1}^{K} \beta_{\mathrm{k}} \mathrm{X}_{\mathrm{c}, \mathrm{t}}+\sum_{j=1}^{J} \gamma_{\mathrm{j}} \mathrm{Z}_{\mathrm{i}, \mathrm{t}-1}+\varphi_{1} \mathrm{Own}_{\mathrm{i}, \mathrm{t}}+\mathrm{k}_{1} \text { Crisis }+\varepsilon_{i t}
$$

where the error component is decomposed into: $\varepsilon_{\mathrm{it}}=\mathrm{v}_{\mathrm{i}}+\mathrm{u}_{\mathrm{it}}, i$ denotes individual bank operating in host country $c$ during year $t . \Delta \mathrm{L}_{\mathrm{i}, \mathrm{t}}$ is the credit growth of bank i during year t. $\mathrm{X}_{\mathrm{c}, \mathrm{t}}$ is a vector of host country macroeconomic variables including Inflation rate, Interest rate and growth rate of real GDP. $Z_{i, t-1}$ is a vector of bank specific control variables, namely economic capital ratio, liquidity, size, profitability and loan impairments. Crisis is a dummy variable for Global financial crisis, which equals 1 
for the year 2008. Finally $\mathrm{Own}_{\mathrm{i}, \mathrm{t}}$ is a binary dummy variable for the type of ownership of bank i during year t.

The model as written in Equation (4.1) has several potential limitations. First, timeinvariant bank fixed characteristics such as corporate strategy, governance and reputation, can be correlated with the other time varying explanatory variables ${ }^{7}$ and will be a part of the error term if omitted. The omission of such variables can lead to biased estimates. However those variables are unobservable, therefore they should be removed from the error term. The standard way to do this is estimating a "fixed effects" model, which conducts a "within transformation". The within transformation means that for each bank i Equation (4.1) is averaged over time and then the averages are subtracted from the original Equation (4.1). The unobservable individual bank characteristics $\left(\mathrm{v}_{\mathrm{i}}\right)$ are constant over time. As a result, they are removed from the error term.

Another problem arises once the lagged dependent variable is included as a regressor in the model. The within transformation introduces a correlation between the transformed lagged variable $\left(\Delta \mathrm{L}_{\mathrm{i}, \mathrm{t}-1}-\frac{1}{\mathrm{~T}} \sum_{\mathrm{t}=0}^{\mathrm{T}-1} \Delta \mathrm{L}_{\mathrm{i}, \mathrm{t}}\right)$ and the transformed error $\left(\varepsilon_{\mathrm{it}}-\frac{1}{\mathrm{~T}} \sum_{\mathrm{t}=1}^{\mathrm{T}} \varepsilon_{\mathrm{it}}\right)$ because the average error includes $\varepsilon_{\mathrm{it}-1}$. The correlation between the error and the lagged dependent variable becomes smaller as the number of time periods $(\mathrm{T})$ increases, because $\varepsilon_{\mathrm{it}-1}$ becomes a smaller component of the error term. However, this is not the case here since there are few time periods $(T=15)$ relative to the number of banks $(\mathrm{N}=323)$. Therefore, a fixed effect method gives biased estimators for the coefficient of the lagged dependent variable, which are particularly

\footnotetext{
${ }^{7}$ For example the reputation of a bank may impact the capability that a bank has in attracting deposits.
} 
biased downwards (Nickell, 1981). If any regressor is correlated to some extent with the lagged dependent variable, its coefficient may be seriously biased too. Moreover, when a panel is unbalanced and in the presence of endogenous variables, a fixed effects estimator is inappropriate to make reliable inferences on the coefficients of all regressors (Flannery \& Hankins, 2013). Here the panel dataset is unbalanced and the literature describes the employed regressors as susceptible of following a cointegrating process (Brissimis \& Delis, 2009). If bank loans and another balance sheet position are strongly correlated it is not clear a priori if/which factor drives the other. To deal with this issue all bank characteristics enter the regression with a lag, similarly to Jeon, Olivero, \& Wu (2013) and Cull \& Martinez (2013). This way simultaneity can be precluded. However, endogeneity concerns are not fully mitigated. A bank might manage its positions in a way that enables it to reach specific credit growth targets each year. A bank might manage its capital ratio, liquidity and deposit rate in order to enable a certain credit expansion the year ahead. To address any endogeneity concerns, a GMM estimation method is employed. GMM estimators use lagged variables as instruments. They extract the exogenous component of the independent variables, allowing for a consistent estimation of the parameters. Specifically a system GMM is selected, which has been found to provide the most reliable estimates under all aforementioned circumstances with unbalanced panels (Flannery \& Hankins, 2013; Roodman, 2006). A two-step estimator is used since it is asymptotically more efficient than the respective one-step estimator. However, this procedure introduces a downward bias in the standard errors. To correct for this, Windmeijer's correction is employed. Moreover robust standard errors are used. Estimation results of a Fixed Effects model and difference GMM model will be provided for reference. 
A system GMM estimator estimates a two-equation system: i) a levels' equation instrumenting it with first differences of variables and ii) first differences the panel and instruments this equation with the lagged variables' levels (Blundell \& Bond, 1998). Instead of the first differences the study employs forward orthogonal deviations from the sample mean, a modification introduced by Arellano and Bover (1995). In order to eliminate the fixed effect from the error term, the average of all available future observations is subtracted, instead of subtracting the past observation. This method performs better than first differences (Hayakawa, 2009).

To address potential endogeneity of bank financials and avoid instrument proliferation, those are instrumented with their second, third and the fourth $\operatorname{lag}^{8}$ and the backward orthogonal deviations transformation is applied to the instruments for the transformed equation ${ }^{9}$. Macroeconomic conditions and ownership variables are treated as exogenous. It has been taken care that results are always conforming to the rule of thumb to maintain the number of instruments below the number of individual banks (Roodman, 2006). Two tests are available to check the joint validity of the instruments, Sargan and Hansen J. Sargan's statistic is inconsistent when non sphericity is suspected in the errors (Roodman, 2006). During the sample period both global and the Eurozone crisis introduce a deviation from sphericity in the form of heteroscedasticity in the data. Moreover, whenever ownership changes, shocks to

\footnotetext{
${ }^{8}$ In the Difference GMM have been used the second to the fifth lag as instruments and backward and orthogonal deviations.

${ }^{9}$ The combination of backward orthogonal deviations for the instruments and forward for the regressors is less biased and more stable than traditional transformation especially for Difference GMM estimations (Hayakawa, 2009).
} 
individual banks are also a reason to avoid reliance on Sargan's statistic. Instead, the study relies upon Hansen's J statistic to check the selection of instruments.

The model described above -Equation (4.1)- are estimated three times, using each time a different definition for ownership. The first one is captured with a dummy variable that equals 1 if the largest shareholder is foreign (irrespectively of the percentage owned). For example, the largest foreign shareholder may hold $10 \%$ of shares and not a controlling stake. A second dummy is taking value 1 if the largest shareholder is foreign and controls the bank owning more than $49.9 \%$ of total shares. As for the previous definition of foreign ownership, the identity of the owner can be diverse: a commercial entity, an individual or another bank. The third ownership dummy equals 1 if the largest shareholder is foreign, controls the bank with a percentage of shares over $49.9 \%$ and the owner can be clearly identified with a financial group, thus excluding the other categories previously included. This latter categorization allows the identification of a subsidiary as a "member of a financial group".

\subsection{Crossed Random Effects Models}

The objective of this section is to investigate further the origins of the heterogeneity of loan growth across subsidiaries belonging to different international financial groups (referred thereafter as "parents") and operating in different markets. Multilevel models are to answer these questions (Rabe-Hesketh \& Skrondal, 2008). An examination of the structure of the data is required to choose the best model. Over time ownership of a subsidiary may change. A single financial group can own several banks in a given year. As a result, there are many combinations of bank-year, financial group-year and bank-financial group occurring multiple times (see Appendix 
Figure C-1 for an exemplification). A Crossed Random Effects Model (Chapter 11, Rabe-Hesketh \& Skrondal, 2008) is chosen to conduct the analysis. Parent characteristics may affect subsidiaries' credit growth as well as regional market developments common to all banks. A crossed random effects model allows for a clear distinction between parent bank and market dynamics. It also addresses the quantification of the relative importance of those effects. There are also included controls for country specific specificities, namely the country of operation of the subsidiary and the country of residence of the parent bank.

The initial stage of the investigation hypothesizes that all subsidiaries are affected similarly by some events in a given year. Therefore, the study considers the main effect of time and treats years as crossed with the observations. Moreover, it is assumed that being part of a specific financial group translates into a common corporate culture, strategy and financial conditions affecting each single subsidiary in the same way, irrespectively of the market of operation. The above hypotheses can be tested through the estimation of the following model:

$$
\Delta \mathrm{L}_{\mathrm{i}, \mathrm{t}}=\underbrace{\alpha_{0}+\sum_{\mathrm{k}=1}^{\mathrm{K}} \beta_{\mathrm{k}} \mathrm{X}_{\mathrm{c}, \mathrm{t}}+\sum_{\mathrm{j}=1}^{\mathrm{J}} \gamma_{\mathrm{j}} \mathrm{Z}_{\mathrm{i}, \mathrm{t}-1}+\mathrm{k}_{1} \text { Crisis }}_{\text {fixed components }}+\underbrace{\zeta_{1 \mathrm{t}}+\zeta_{2 \mathrm{p}}+\varepsilon_{\mathrm{itp}}}_{\text {random components }}
$$

Letter $\mathrm{i}$ denotes subsidiary, $\mathrm{c}$ host country, $\mathrm{t}$ year and $\mathrm{p}$ the parent. $\zeta_{1 \mathrm{t}}$ is a random intercept for years, $\zeta_{2 p}$ is a random intercept for parents and $\varepsilon_{i t p}$ is a residual error term. $\alpha_{0}$ is the mean intercept. The random variables ensure that the intercept $\left(\alpha_{0}+\zeta_{1 \mathrm{t}}+\zeta_{2 \mathrm{p}}\right)$ is unique and random to every parent and year. The random intercept for years $\zeta_{1 \mathrm{t}}$ is shared across all subsidiaries for a given year, whereas the random 
intercept for parents $\zeta_{2 p}$ is shared by all years for a given parent. $X_{c, t}$ is a vector of macroeconomic variables, $\mathrm{Z}_{\mathrm{i}, \mathrm{t}-1}$ is a vector of bank specific control variables and Crisis is a dummy variable for Global financial crisis.

The estimation of Equation (4.2) demands the assumption that the error term has a zero mean and is independent across banks and years. Moreover, the random intercepts $\zeta_{1 \mathrm{t}} \& \zeta_{2 \mathrm{p}}$ have zero means, are independent of each other, across years and across financial groups, independent of all right hand variables and uncorrelated with $\varepsilon_{\text {itp. }}$ These assumptions force the omission of the lagged dependent variable from the regressors. $\zeta_{2 p}$ represents the combined effect on credit growth of all unobserved parent specific variables that do not change over time. It is a determinant both of credit growth and of lagged credit growth. Once the lagged dependent variable is included, $\zeta_{2 p}$ ceases to be statistically independent of it.

A second Crossed Random Effects Model allows for an interaction between years and parents. Therefore, the assumption of parents and years exerting independent effects is relaxed. Instead, the study accounts for the possibility that some events during year $\mathrm{t}$ may be more detrimental or beneficial to a certain parent and less to another. Therefore, the model in Equation (4.2) becomes:

$$
\Delta \mathrm{L}_{\mathrm{i}, \mathrm{t}}=\underbrace{\alpha_{0}+\sum_{\mathrm{k}=1}^{\mathrm{K}} \beta_{\mathrm{k}} \mathrm{X}_{\mathrm{c}, \mathrm{t}}+\sum_{\mathrm{j}=1}^{\mathrm{J}} \gamma_{\mathrm{j}} \mathrm{Z}_{\mathrm{i}, \mathrm{t}-1}+\mathrm{k}_{1} \text { Crisis }}_{\text {fixed components }}+\underbrace{\zeta_{1 \mathrm{t}}+\zeta_{2 \mathrm{p}}+\zeta_{3 \mathrm{tp}}+\varepsilon_{\mathrm{itp}}}_{\text {random components }}
$$

where $\zeta_{1 \mathrm{t}}$ is a random intercept for years, $\zeta_{2 \mathrm{p}}$ is a random term for parents and $\zeta_{3 \mathrm{tp}}$ is a random term for parents interacted with years. $\zeta_{3 \text { tp }}$ is assumed independent of the 
other random terms $\zeta_{1 \mathrm{t}} \& \zeta_{2 \mathrm{p}}$ and across combinations of years and parents. The residual term $\varepsilon_{\text {itp }}$ represents the deviation of a subsidiary's response from the mean for year $\mathrm{t}$ and financial group $\mathrm{p}$.

A way to interpret the relative magnitude of the random variance components is calculating the intra-class correlations $(\rho)$. This is a measure of how much of the total variance is attributed to the random components. This indicator increases under positively correlated events. For example, it is higher when the responses of the single observations are more alike. Its value can range between $0 \%$ and $100 \%$. $0 \%$ means that observations in a certain cluster have nothing in common. Therefore, the grouping makes no sense. $100 \%$ means absolute agreement and no variance across individual observations.

The models allow us to calculate the following intra-class correlations ${ }^{10}$ :

Subsidiaries operating during the same year but belong to different parents

$$
\rho(\text { year })=\frac{\sigma_{\zeta_{1 \mathrm{t}}}^{2}}{\sigma_{\zeta_{1 \mathrm{t}}}^{2}+\sigma_{\zeta_{2 \mathrm{p}}}^{2}+\sigma_{\zeta_{3 \mathrm{tp}}}^{2}+\sigma_{\varepsilon_{\mathrm{itp}}}^{2}}
$$

Subsidiaries belonging to the same parent but operate during different years

$$
\rho(\text { parent })=\frac{\sigma_{\zeta_{2 t}}^{2}}{\sigma_{\zeta_{1 \mathrm{t}}}^{2}+\sigma_{\zeta_{2 \mathrm{p}}}^{2}+\sigma_{\zeta_{3 \mathrm{tp}}}^{2}+\sigma_{\varepsilon_{\text {itp }}}^{2}}
$$

Subsidiaries belonging to the same parent and operating during the same year

${ }^{10}$ Chapter 11.6, page 485 in Rabe-Hesketh \& Skrondal,2008 


$$
\rho(\text { year, parent })=\frac{\sigma_{\zeta_{1 \mathrm{t}}}^{2}+\sigma_{\zeta_{2 \mathrm{p}}}^{2}+\sigma_{\zeta_{3 \mathrm{tp}}}^{2}}{\sigma_{\zeta_{1 \mathrm{t}}}^{2}+\sigma_{\zeta_{2 \mathrm{p}}}^{2}+\sigma_{\zeta_{3 \mathrm{tp}}}^{2}+\sigma_{\varepsilon_{\text {itp }}}^{2}}
$$

Equation (4.6) can also be calculated after the estimation of Equation (4.2), assuming $\sigma_{\zeta_{3 t p}}^{2}$ equal to 0.

The host and home country effects have also been investigated. To do so, in Equation (4.2) and Equation (4.3) the random effect of parent has been replaced with a random effect of host/home country and the interaction of this random effect with years.

The estimation results of all these models are employed as an indicator of those factors that matter for subsidiary credit extensions. Therefore, these results are used to improve the baseline specification, thus including interaction and time-varying characteristics as required.

\subsection{Dynamic credit growth with controls for parent's financials}

The results stemming from the exercise conducted with the models in section 0 indicate that the heterogeneity of credit growth across subsidiaries to a large extent can be attributed to time variant parent characteristics. Therefore, the nexus parentsubsidiaries must be investigated further. This is achieved with the inclusion of factors affecting subsidiaries owned by the same parent. Conceptually the dummy for ownership included in Equation (4.1) is substituted with a set of parent banks' balance sheet characteristics, namely: bank profitability, solvency, liquidity and asset quality. Parent deposit ratio is excluded, because parent banks do not ground their international expansion strategies and decisions on this ratio. Finally the study 
controls for growth and demand conditions in the home country because these may affect expansion of credit at subsidiary level.

The Dynamic Model becomes:

$$
\begin{gathered}
\Delta \mathrm{L}_{\mathrm{i}, \mathrm{t}}=\alpha_{0}+\alpha_{1} \Delta \mathrm{L}_{\mathrm{i}, \mathrm{t}-1}+\sum_{\mathrm{k}=1}^{\mathrm{K}} \beta_{\mathrm{k}} \mathrm{X}_{\mathrm{c}, \mathrm{t}}+\sum_{\mathrm{j}=1}^{\mathrm{J}} \gamma_{\mathrm{j}} \mathrm{Z}_{\mathrm{i}, \mathrm{t}-1}+\sum_{\mathrm{k}=1}^{\mathrm{K}} \delta_{\mathrm{k}} \mathrm{PX} \mathrm{X}_{\mathrm{t}} \\
+\sum_{\mathrm{j}=1}^{\mathrm{J}} \psi_{\mathrm{j}} \mathrm{PZ}_{\mathrm{p}, \mathrm{t}-1}+\mathrm{k}_{1} \text { Crisis }+\varepsilon_{\mathrm{it}}
\end{gathered}
$$

The error component $\varepsilon_{\mathrm{it}}$ is decomposed into: $\varepsilon_{\mathrm{it}}=\mathrm{v}_{\mathrm{i}}+\mathrm{u}_{\mathrm{it}}$, as time invariant subsidiary specific characteristics potentially are assumed to be correlated with the regressors. $i$ denotes subsidiary operating in host country $c$ during year $t$ and belonging to parent $p$, which is headquartered in country $\eta . \Delta \mathrm{L}_{\mathrm{i}, \mathrm{t}}$ is the credit growth of subsidiary $i$ during year $t$, which is included as explanatory variable too with one year lag. $\mathrm{X}_{\mathrm{c}, \mathrm{t}}$ is a vector of host country macroeconomic variables including Inflation rate, Interest rate and growth rate of real GDP. $Z_{i, t-1}$ is a vector of subsidiary specific control variables, namely economic capital ratio, liquidity, size, profitability and loan impairments. $P X_{\eta, t}$ is a vector of parent's home country macroeconomic variables (Inflation rate, Interest rate and real GDP growth). $P \mathrm{Z}_{\mathrm{i}, \mathrm{t}-1}$ is a vector of parent specific control variables, namely the economic capital ratio of the parent, parent liquidity, parent profitability and loan impairments. Finally Crisis is a dummy variable for Global financial crisis, which equals 1 for the year 2008.

The preferred estimation method is a system GMM model with forward orthogonal deviations. Subsidiaries' balance sheet variables are treated as potentially endogenous 
for the reasons described in section Chapter 65466 and are instrumented with their second lag ${ }^{11}$. A two-step system GMM estimator is employed with Windmeijer's correction and robust standard errors. Difference GMM and Fixed effects estimation results are reported also. The new element is the treatment of the financial characteristics of the parents. Parent's credit extension policy is steered by the conglomerates' strategic decisions, which can change over time. Those can affect both the credit growth in a certain country and the capital structure at consolidated level. Parents might target certain profitability and certain credit growth in each country and set targets for each country manager. Therefore, parents adjust their capital structure, liquidity and other financials in a way to render subsidiaries' targets feasible. Strategic decisions are an omitted variable for which a researcher cannot control and which affect the independent variable and the variables at parent level. Therefore, an omitted variable bias may generate endogeneity. Following previous literature (De Haas \& Van Lelyveld, 2010; Jeon, Olivero, \& Wu, 2013), this study precludes any endogeneity issues on the ground of the subsidiaries' relative size compared with their parent. If the subsidiary is small relative to the overall group size the omitted variable bias is considered to have an immaterial effect on the results. In the present study, the average subsidiary accounts for about 2.3 per cent of its parent bank's assets ${ }^{12}$, while in De Haas and Van Lelyveld (2010) the average subsidiary is 10 per cent of the parent bank. Parent bank characteristics are included with one year lag. Moreover,

\footnotetext{
${ }^{11}$ When a Difference GMM estimator is employed, those variables are instrumented with their second and third lag.

${ }^{12}$ There are 2040 subsidiary observations out of which a) 1755 constitute less than $10 \%$ of the parent, b) 72 are above $10 \%$ and below $20 \%$ of the parent; c) 13 observations are above $20 \%$ of the parent
} 
they are included as exogenous instruments only for the levels' equation, where they are assumed uncorrelated with the contemporaneous error ${ }^{13}$.

\footnotetext{
${ }^{13}$ Following Stata's help file for the xtabond2 command. Here it is implicitly assumed that once parent bank characteristics are transformed into differences they cease to be exogenous, therefore they are treated as predetermined variables. When a difference GMM model is estimated, the transformation of those variables is prevented and they are included as levels.
} 



\section{Chapter 5 Results}

\subsection{Dynamic credit growth and ownership}

The first set of regressions investigates the effect of ownership on credit growth at subsidiary level. Equation (4.1) is estimated using a system GMM model controlling for all types of foreign ownership of the banks in our sample. Table 5-1 reports the estimation results. It includes a set of models including a different set of dummy variables, which capture different definitions of foreign ownership. As a result, all types of foreign ownership are significant and exert a positive effect on subsidiaries' credit growth. Foreign participated banks tend to extend credit more than their domestically owned competitors. Consequently, foreign ownership matters.

Yet, the types of foreign participation might not be equally important to the host market economies. Members of financial groups might drive the results of all types of banks with a relatively large foreign shareholder. The reason is that those constitute the largest majority of all the banks with some sort of foreign participation in their ownership structure. As reported in Figure 3-2, 67\% of the total observations are banks whose largest shareholder is foreign and 57\% are banks controlled by foreign financial groups. Table 5-2 reports further regressions including a binary variable for a) an owner being a foreign financial group and holding over $50 \%$ of shares b) a foreign non-financial entity/individual holding over $50 \%$ of shares c) a foreign entity/ 
individual being majority shareholder and holding less than $50 \%$ of shares. Those categories are mutually exclusive and are compared to domestic banks without any sort of foreign participation.

Table 5-1: Factors affecting loan growth - estimations based on Equation (4.1) - including different definitions of foreign ownership

\begin{tabular}{|c|c|c|c|}
\hline $\begin{array}{l}\text { Dependent variable: } \\
\text { Loan Growth }\end{array}$ & $\begin{array}{l}\text { (1) } \\
\text { The majority } \\
\text { shareholder } \\
\text { is a foreigner }\end{array}$ & $\begin{array}{c}(2) \\
\text { A foreigner } \\
\text { owns } \\
\text { at least } 50 \% \text { of shares }\end{array}$ & $\begin{array}{c}(3) \\
\text { A financial group } \\
\text { owns } \\
\text { at least } 50 \% \text { of shares }\end{array}$ \\
\hline Loan growth, 1st lag & $\begin{array}{l}0.261 * * * \\
(0.026)\end{array}$ & $\begin{array}{l}0.260 * * * \\
(0.027)\end{array}$ & $\begin{array}{l}0.261 * * * \\
(0.027)\end{array}$ \\
\hline Economic Capital, 1st lag & $\begin{array}{c}-0.388 * * \\
(0.181)\end{array}$ & $\begin{array}{c}-0.411^{* *} \\
(0.182)\end{array}$ & $\begin{array}{c}-0.430 * * \\
(0.178)\end{array}$ \\
\hline Liquidity, 1st lag & $\begin{array}{c}0.493 * * * \\
(0.086)\end{array}$ & $\begin{array}{c}0.482 * * * \\
(0.087)\end{array}$ & $\begin{array}{c}0.480 * * * \\
(0.084)\end{array}$ \\
\hline Size, 1st lag & $\begin{array}{c}-5.032 * * * \\
(1.120)\end{array}$ & $\begin{array}{c}-5.166 * * * \\
(1.121)\end{array}$ & $\begin{array}{c}-5.291 * * * \\
(1.144)\end{array}$ \\
\hline Profitability, 1st lag & $\begin{array}{c}1.558 * * * \\
(0.557)\end{array}$ & $\begin{array}{c}1.556 * * * \\
(0.558)\end{array}$ & $\begin{array}{c}1.583 * * * \\
(0.555)\end{array}$ \\
\hline Deposit rate, 1 st lag & $\begin{array}{l}-0.021 \\
(0.055)\end{array}$ & $\begin{array}{l}-0.017 \\
(0.055)\end{array}$ & $\begin{array}{l}-0.017 \\
(0.054)\end{array}$ \\
\hline Loan Impairments, 1st lag & $\begin{array}{l}-0.069 \\
(0.087)\end{array}$ & $\begin{array}{l}-0.087 \\
(0.088)\end{array}$ & $\begin{array}{l}-0.091 \\
(0.089)\end{array}$ \\
\hline GDP growth & $\begin{array}{l}1.054 * * * \\
(0.181)\end{array}$ & $\begin{array}{l}1.150 * * * \\
(0.167)\end{array}$ & $\begin{array}{l}1.142 * * * \\
(0.172)\end{array}$ \\
\hline Inflation rate & $\begin{array}{l}0.683 * * * \\
(0.191)\end{array}$ & $\begin{array}{l}0.494 * * * \\
(0.189)\end{array}$ & $\begin{array}{l}0.487 * * \\
(0.189)\end{array}$ \\
\hline Interest rate & $\begin{array}{c}-0.552 * * \\
(0.218)\end{array}$ & $\begin{array}{l}-0.334 \\
(0.213)\end{array}$ & $\begin{array}{l}-0.354 \\
(0.216)\end{array}$ \\
\hline Global financial crisis & $\begin{array}{c}-7.970 * * * \\
(1.648)\end{array}$ & $\begin{array}{c}-7.416 * * * \\
(1.623)\end{array}$ & $\begin{array}{c}-7.479 * * * \\
(1.625)\end{array}$ \\
\hline Owner: largest shareholder foreign & $\begin{array}{l}7.048 * * * \\
(1.665)\end{array}$ & & \\
\hline $\begin{array}{l}\text { Owner: at least } 50 \% \text { foreign } \\
\text { ownership }\end{array}$ & & $\begin{array}{l}7.115 * * * \\
(1.668)\end{array}$ & \\
\hline Owner: foreign financial group & & & $\begin{array}{c}5.999 * * * \\
(1.739)\end{array}$ \\
\hline Constant & $\begin{array}{l}69.144 * * * \\
(19.149)\end{array}$ & $\begin{array}{l}70.359 * * * \\
(19.103)\end{array}$ & $\begin{array}{l}75.031 * * * \\
(19.095)\end{array}$ \\
\hline Observations & 2,775 & 2,775 & 2,775 \\
\hline Number of id & 310 & 310 & 310 \\
\hline No of instruments & 306 & 306 & 306 \\
\hline AR-2 & 0.512 & 0.518 & 0.527 \\
\hline Hansen $\mathbf{J}$ & 0.403 & 0.403 & 0.435 \\
\hline
\end{tabular}

Robust standard errors in parentheses; *** $\mathrm{p}<0.01$, ** $\mathrm{p}<0.05, * \mathrm{p}<0.1$; The Arellano-Bover/Blundell-Bond estimator (system GMM) was used to produce the results above. 'AR-2' is the p-value of the Arellano - Bond test. The H0 is that the average autocovariance in the residuals is of order 2. 'Hansen $\mathrm{J}$ ' is the p-value of the Hansen J test for overidentifying restrictions, which is asymptotically distributed as chi2 under the null of instrument validity. Economic Capital is the ratio of equity to total assets. Liquidity is the ratio of liquid assets to total assets. Size is the natural logarithm of total assets. Loan Impairments is the ratio of loan impairment charges to gross loans. Deposit ratio is the ratio of customer deposits to total funding. Global financial crisis is a dummy for year 2008; All ratios are expressed in \%. 
Results indicate that all kinds of foreign participated banks have a higher propensity to extent credit than purely domestic banks. All types of foreign participation in the ownership structure are crucial to the performance of the subsidiary, with members of foreign financial groups bearing the largest influence and most significant one. Moreover, members of foreign financial groups constitute the most uniform category of foreign ownership in terms of business objectives, financial structure and operation. On the other hand, among the foreign non-financials owners one can see individuals, industrials, international institutions and funds originated from the Middle East. Given that members of financial groups cover the vast majority of cases too, the rest of the research focuses on this category of foreign ownership alike previous literature i.e. De Haas and Van Lelyveld (2006; 2010; 2014), Allen et al. (2015), Cull and Martinez Peria (2013).

Constraining the analysis to the definition of foreign ownership as membership to financial groups, Equation (4.1) is re-estimated using different methods to check the robustness of the previous findings. Results are reported in Table 5-3. Economic growth and inflation rate in the host country correlate positively with individual bank credit growth. This supports the idea that higher growth triggers credit growth as well as more robust inflation generates larger asset price increases, ultimately stimulating more credit via amplified asset evaluations. On the other hand, interest rates have a negative effect on credit growth. This suggests that borrowers are more reluctant to demand more debt when interest rates move up. The global financial crisis of 2008 was also detected to be detrimental to credit expansion. 
Past loan growth has a positive effect on current credit growth. However, bank's size has a negative impact suggesting that large banks expand their loan portfolio at a slower pace. Finally, higher liquidity levels and partially profitability have a positive effect on credit growth as expected. To the contrary, the quality of assets (loan

Table 5-2: Estimations based on Equation (4.1) - including the effect of mutually exclusive definitions of foreign ownership versus purely domestically owned banks

\begin{tabular}{|c|c|c|c|}
\hline $\begin{array}{l}\text { Dependent variable: } \\
\text { Loan Growth }\end{array}$ & $\begin{array}{c}\text { (1) } \\
\text { A financial group } \\
\text { owns } \\
\text { at least } 50 \% \text { of shares }\end{array}$ & $\begin{array}{c}\text { (2) } \\
\text { Foreign non- } \\
\text { financials } \\
\text { own over } 50 \% \\
\end{array}$ & $\begin{array}{l}\text { (3) } \\
\text { Foreigners are majority } \\
\text { shareholders } \\
\text { and own less than } 50 \%\end{array}$ \\
\hline Loan growth, 1st lag & $\begin{array}{c}0.248 * * * \\
(0.029)\end{array}$ & $\begin{array}{c}0.290 * * * \\
(0.052)\end{array}$ & $\begin{array}{c}0.210 * * * \\
(0.038)\end{array}$ \\
\hline Economic Capital, 1st lag & $\begin{array}{c}-0.338^{*} \\
(0.196)\end{array}$ & $\begin{array}{c}0.041 \\
(0.260)\end{array}$ & $\begin{array}{l}-1.120 \\
(0.719)\end{array}$ \\
\hline Liquidity, 1st lag & $\begin{array}{c}0.513 * * * \\
(0.089)\end{array}$ & $\begin{array}{c}0.322 * * \\
(0.155)\end{array}$ & $\begin{array}{c}0.466 * * \\
(0.197)\end{array}$ \\
\hline Size, 1st lag & $\begin{array}{c}-6.192 * * * \\
(1.261)\end{array}$ & $\begin{array}{l}-2.270 \\
(1.755)\end{array}$ & $\begin{array}{c}-12.630 * * * \\
(3.486)\end{array}$ \\
\hline Profitability, 1st lag & $\begin{array}{l}1.030^{*} \\
(0.571)\end{array}$ & $\begin{array}{c}2.077 * * * \\
(0.774)\end{array}$ & $\begin{array}{l}2.038^{*} \\
(1.043)\end{array}$ \\
\hline Deposit rate, 1 st lag & $\begin{array}{l}-0.072 \\
(0.061)\end{array}$ & $\begin{array}{l}-0.002 \\
(0.081)\end{array}$ & $\begin{array}{l}-0.066 \\
(0.185)\end{array}$ \\
\hline Loan Impairments, 1st lag & $\begin{array}{l}-0.063 \\
(0.098)\end{array}$ & $\begin{array}{c}0.177 \\
(0.216)\end{array}$ & $\begin{array}{l}0.020 \\
(0.295)\end{array}$ \\
\hline GDP growth & $\begin{array}{c}1.154 * * * \\
(0.212)\end{array}$ & $\begin{array}{c}0.818 * * * \\
(0.312)\end{array}$ & $\begin{array}{l}0.310 \\
(0.488)\end{array}$ \\
\hline Inflation rate & $\begin{array}{c}0.148 \\
(0.146)\end{array}$ & $\begin{array}{c}0.385 \\
(0.268)\end{array}$ & $\begin{array}{c}0.320 \\
(0.298)\end{array}$ \\
\hline Interest rate & $\begin{array}{l}-0.204 \\
(0.205)\end{array}$ & $\begin{array}{l}-0.195 \\
(0.268)\end{array}$ & $\begin{array}{l}-0.292 \\
(0.710)\end{array}$ \\
\hline Global financial crisis & $\begin{array}{c}-5.782 * * * \\
(1.692)\end{array}$ & $\begin{array}{l}-5.638^{*} \\
(3.400)\end{array}$ & $\begin{array}{l}-2.982 \\
(4.166)\end{array}$ \\
\hline A foreign financial group owns over $50 \%$ & $\begin{array}{c}8.270 * * * \\
(2.295)\end{array}$ & & \\
\hline Foreign non-financials own over $50 \%$ & & $\begin{array}{c}6.260 * * \\
(2.559)\end{array}$ & \\
\hline $\begin{array}{l}\text { Foreigners are majority shareholders } \\
\text { and own less than } 50 \%\end{array}$ & & & $\begin{array}{l}6.688^{*} \\
(3.752)\end{array}$ \\
\hline Constant & $\begin{array}{l}87.245 * * * \\
(20.834)\end{array}$ & $\begin{array}{c}26.733 \\
(29.297)\end{array}$ & $\begin{array}{c}186.018 * * * \\
(54.168)\end{array}$ \\
\hline Observations & 2,485 & 1,052 & 894 \\
\hline No of banks & 291 & 159 & 130 \\
\hline No of instruments & 243 & 145 & 90 \\
\hline AR-2 & 0.630 & 0.736 & 0.362 \\
\hline Hansen $\mathbf{J}$ & 0.162 & 0.880 & 0.622 \\
\hline
\end{tabular}

impairment charges ratio) affects negatively credit extensions. Ceteris paribus, members of foreign financial groups consistently have a higher propensity to expand credit. This is in contrast with Allen et al (2015), who found ownership structure 
insignificant. It contrasts also De Haas and Van Lelyveld (2006), who show ownership to matter per se only during periods of financial crises. Cull \& Martinez (2013), report that ownership matters in CEESE countries concerning solely the growth of corporate loans. The only study that reaches a result similar to this one was conducted by Bakker et al. (2013) and constitutes part of an IMF's report concerning the current region of focus.

Table 5-3: Factors affecting loan growth - estimations based on Equation (4.1) - including the effect of being a member of a foreign financial group (subsidiary bank)

\begin{tabular}{|c|c|c|c|c|c|}
\hline $\begin{array}{l}\text { Dependent variable: } \\
\text { Loan Growth }\end{array}$ & $\begin{array}{l}\text { (1) } \\
\text { FE }\end{array}$ & $\begin{array}{c}(2) \\
\text { sys GMM } \\
\end{array}$ & $\begin{array}{c}(3) \\
\text { Diff GMM }\end{array}$ & $\begin{array}{c}\text { (4) } \\
\text { sys GMM } \\
\end{array}$ & $\begin{array}{c}(5) \\
\text { diff GMM }\end{array}$ \\
\hline Loan growth, 1st lag & $\begin{array}{c}0.154 * * * \\
(0.026)\end{array}$ & $\begin{array}{c}0.261 * * * \\
(0.027)\end{array}$ & $\begin{array}{c}0.173 * * * \\
(0.027)\end{array}$ & $\begin{array}{c}0.181 * * * \\
(0.046)\end{array}$ & $\begin{array}{l}0.094^{*} \\
(0.049)\end{array}$ \\
\hline Economic Capital, 1st lag & $\begin{array}{c}0.121 \\
(0.163)\end{array}$ & $\begin{array}{c}-0.430 * * \\
(0.178)\end{array}$ & $\begin{array}{c}0.167 \\
(0.299)\end{array}$ & $\begin{array}{l}-0.200 \\
(0.658)\end{array}$ & $\begin{array}{c}0.880 \\
(0.693)\end{array}$ \\
\hline Liquidity, 1st lag & $\begin{array}{c}0.488^{* * * *} \\
(0.050)\end{array}$ & $\begin{array}{c}0.480 * * * \\
(0.084)\end{array}$ & $\begin{array}{c}0.632 * * * \\
(0.132)\end{array}$ & $\begin{array}{c}0.430 * * * \\
(0.165)\end{array}$ & $\begin{array}{c}0.560 * * * \\
(0.163)\end{array}$ \\
\hline Size, 1st lag & $\begin{array}{c}-16.268 * * * \\
(1.362)\end{array}$ & $\begin{array}{l}-5.291 * * * \\
(1.144)\end{array}$ & $\begin{array}{c}-15.898 * * * \\
(2.575)\end{array}$ & $\begin{array}{c}-7.814 * * \\
(3.549)\end{array}$ & $\begin{array}{c}-26.958 * * * \\
(8.835)\end{array}$ \\
\hline Profitability, 1st lag & $\begin{array}{l}1.096 * * * \\
(0.400)\end{array}$ & $\begin{array}{c}1.583 * * * \\
(0.555)\end{array}$ & $\begin{array}{c}0.944 \\
(0.680)\end{array}$ & $\begin{array}{c}1.259 \\
(0.886)\end{array}$ & $\begin{array}{c}0.804 \\
(0.752)\end{array}$ \\
\hline Deposit rate, 1 st lag & $\begin{array}{l}-0.004 \\
(0.065)\end{array}$ & $\begin{array}{l}-0.017 \\
(0.054)\end{array}$ & $\begin{array}{l}-0.160 \\
(0.118)\end{array}$ & $\begin{array}{c}0.054 \\
(0.144)\end{array}$ & $\begin{array}{c}-0.585 * * * \\
(0.185)\end{array}$ \\
\hline Loan Impairments, 1st lag & $\begin{array}{c}-0.115 * * * \\
(0.040)\end{array}$ & $\begin{array}{l}-0.091 \\
(0.089)\end{array}$ & $\begin{array}{c}-0.443 * * * \\
(0.155)\end{array}$ & $\begin{array}{c}-0.328 * * \\
(0.154)\end{array}$ & $\begin{array}{l}-0.106 \\
(0.169)\end{array}$ \\
\hline GDP growth & $\begin{array}{c}0.878 * * * \\
(0.148)\end{array}$ & $\begin{array}{c}1.142 * * * \\
(0.172)\end{array}$ & $\begin{array}{c}0.838^{* * * *} \\
(0.163)\end{array}$ & $\begin{array}{c}0.377 \\
(0.332)\end{array}$ & $\begin{array}{c}0.650 * * \\
(0.277)\end{array}$ \\
\hline Inflation rate & $\begin{array}{c}0.521^{* *} \\
(0.210)\end{array}$ & $\begin{array}{c}0.487^{* *} \\
(0.189)\end{array}$ & $\begin{array}{c}0.467 * * \\
(0.211)\end{array}$ & $\begin{array}{c}0.615^{* *} \\
(0.306)\end{array}$ & $\begin{array}{c}0.165 \\
(0.279)\end{array}$ \\
\hline Interest rate & $\begin{array}{c}-0.984 * * * \\
(0.256)\end{array}$ & $\begin{array}{l}-0.354 \\
(0.216)\end{array}$ & $\begin{array}{c}-0.838 * * * \\
(0.284)\end{array}$ & $\begin{array}{l}-0.921 * \\
(0.500)\end{array}$ & $\begin{array}{c}-0.959 * * * \\
(0.357)\end{array}$ \\
\hline Member of a foreign financial group & $\begin{array}{c}14.295 * * * \\
(3.835)\end{array}$ & $\begin{array}{c}5.999 * * * \\
(1.739)\end{array}$ & $\begin{array}{c}12.826 * * * \\
(4.421)\end{array}$ & $\begin{array}{l}9.421 * * \\
(4.143)\end{array}$ & $\begin{array}{c}\text { 13.270*** } \\
(3.425)\end{array}$ \\
\hline Global financial crisis & $\begin{array}{l}-1.365 \\
(1.398)\end{array}$ & $\begin{array}{l}-7.479 * * * \\
(1.625)\end{array}$ & $\begin{array}{c}-3.470 * * \\
(1.705)\end{array}$ & & \\
\hline Constant & $\begin{array}{l}219.891 * * * \\
(22.388)\end{array}$ & $\begin{array}{c}75.031 * * * \\
(19.095)\end{array}$ & & $\begin{array}{c}93.691 \\
(57.049)\end{array}$ & \\
\hline Year dummies & NO & NO & NO & YES & YES \\
\hline $\begin{array}{l}\text { Observations } \\
\text { R-squared }\end{array}$ & $\begin{array}{l}2,775 \\
0.433\end{array}$ & 2,775 & 2,465 & 2,775 & 2,465 \\
\hline No of banks & 310 & 310 & 292 & 310 & 292 \\
\hline No of instruments & & 306 & 271 & 101 & 93 \\
\hline AR-2 & & 0.527 & 0.674 & 0.145 & 0.458 \\
\hline Hansen J & & 0.435 & 0.312 & 0.156 & 0.501 \\
\hline \multicolumn{6}{|c|}{$\begin{array}{l}\text { Robust standard errors in parentheses; } * * * \mathrm{p}<0.01, * * \mathrm{p}<0.05, * \mathrm{p}<0.1 \text {; FE refers to panel estimation controlling for individual } \\
\text { bank fixed effects with robust standard errors. sys GMM refers to estimation using the Arellano-Bover/Blundell-Bond estimator. } \\
\text { diff GMM refers to estimation using the Arellano - Bond difference panel data estimator with robust standard errors.'AR-2' is the } \\
\text { p-value of the Arellano - Bond test. The H0 is that the average autocovariance in the residuals is of order } 3 \text {. 'Hansen J' is the } \mathrm{p}- \\
\text { value of the Hansen } \mathrm{J} \text { test for overidentifying restrictions, which is asymptotically distributed as chi } 2 \text { under the null of } \\
\text { instrument validity. Economic Capital is the ratio of equity to total assets. Liquidity is the ratio of liquid assets to total assets. } \\
\text { Size is the natural logarithm of total assets. Loan Impairments is the ratio of loan impairment charges to gross loans. Deposit } \\
\text { ratio is the ratio of customer deposits to total funding. Global financial crisis is a dummy for year 2008; All ratios are expressed } \\
\text { in \%. }\end{array}$} \\
\hline
\end{tabular}


The question that follows is why being a member of a financial group per se means a larger propensity to extent credit. Those banks might enjoy different levels in their fundamentals that allow them to behave differently. To assess that, the first guess is to conduct an independent samples' t-test. However, current data violate the normality assumptions concerning the distribution of some of the variables (Schmider, Ziegler, Danay, Beyer, \& Bühner, 2010)14. Therefore, a Wilcoxon-Mann-Whitney test is the best solution, since it is a non-parametric analog to the t-test. Results are reported in Table 5-4. With the exception of profitability, domestic banks differ in all other financial fundamentals to members of foreign financial groups.

Table 5-4: Statistical test on differences in the level of characteristics between foreign owned banks and domestic banks

\begin{tabular}{|c|c|c|c|c|c|c|}
\hline \multicolumn{7}{|c|}{ Wilcoxon-Mann Whitney test results } \\
\hline & $\begin{array}{l}\text { Economic } \\
\text { Capital }\end{array}$ & Profitability & Liquidity & Size & $\begin{array}{l}\text { Loan } \\
\text { Impairments }\end{array}$ & Deposit ratio \\
\hline $\begin{array}{l}\mathrm{Z}- \\
\text { statistic }\end{array}$ & 7.720 & 1.413 & 9.727 & -20.419 & 5.619 & 12.234 \\
\hline P-value & 0.0000 & 0.1577 & 0.0000 & 0.0000 & 0.0000 & 0.0000 \\
\hline Result: & $\begin{array}{l}\text { Domestic } \\
\text { banks exhibit } \\
\text { significantly } \\
\text { higher } \\
\text { economic } \\
\text { capital }\end{array}$ & $\begin{array}{l}\text { Not } \\
\text { significant } \\
\text { differences } \\
\text { between the } \\
\text { two bank } \\
\text { categories }\end{array}$ & $\begin{array}{l}\text { Domestic } \\
\text { banks } \\
\text { exhibit } \\
\text { significantly } \\
\text { higher } \\
\text { liquidity } \\
\text { rates }\end{array}$ & $\begin{array}{l}\text { Members of } \\
\text { foreign } \\
\text { financial } \\
\text { groups are } \\
\text { significantly } \\
\text { larger }\end{array}$ & $\begin{array}{l}\text { Domestic } \\
\text { banks have a } \\
\text { higher loan } \\
\text { impairment } \\
\text { rate }\end{array}$ & $\begin{array}{l}\text { Domestic } \\
\text { banks have a } \\
\text { higher } \\
\text { deposit ratio }\end{array}$ \\
\hline
\end{tabular}

Given these results, it is investigated if the differences in the level of the determinants imply a different impact to foreign and domestic banks' credit growth. To evaluate this possibility a Chow test is conducted using fixed effects estimations with robust standard errors. The null hypothesis is that the coefficients of the two groups of

\footnotetext{
${ }^{14}$ Particularly capital ratio, profitability and loan impairment ratio violate the cut-off rule of skew $<\mid 2$.| and kurtosis $<|9.0|$ according to Schmider et al (2010)
} 
banks are the same. This hypothesis is rejected ${ }^{15}$. Equation (4.1) is re-estimated across the two categories of banks, domestic and members of foreign financial groups, and eliminating the ownership variable. Results are reported in Table 5-5 and exhibit three main differences between domestic banks and members of foreign financial groups. Subsidiary banks' lending is pro-cyclical, while domestically owned banks seem irresponsive to the cycle in the host country. Capital conditions also affect more domestic banks than foreign owned banks, whereby higher capital limits domestic banks credit extensions. Finally, foreign owned banks have been more negatively impacted by the global financial crisis.

The estimation results of Model (2) in Table 5-5 are most probably biased. The reason is that one of the assumptions required for the estimation of a system GMM model, cross-sectional independence, is susceptible to violation. Errors might be crosscorrelated due to an omitted effect common across some subsidiaries. Several foreign banks share the same owner. This translates into shared management, risk management systems, same growth / profitability targets, etc. This causes a contemporaneous correlation of the residuals of those banks belonging to the same financial group. On top of this, members of the same financial group share the same funding sources from the same parent bank. Parent banks issue loans to their subsidiaries, having a direct impact in the liquidity of their subsidiaries. The amounts of intragroup loans are a function of the parent banks own financial position. Therefore, a shock at the parent level affects equally the liquidity levels of its subsidiaries.

\footnotetext{
${ }^{15}$ The F-statistic is $F(11,288)=3.49 \&$ the $p$-value $=0.0001$
} 
Table 5-5: Estimations based on Equation (4.1) using the sub-sample of domestic banks (Model 1) and the sub-sample of financial group members (Model 2)

(1)

Dependent variable:

Loan Growth

Loan growth, 1st lag

Economic Capital, 1st lag

Liquidity, 1st lag

Size, 1st lag

Profitability, 1st lag

Deposit rate, 1 st lag

Loan Impairments, 1st lag

GDP growth

Inflation rate

Interest rate

Global financial crisis

Constant

Domestic banks

$$
\begin{gathered}
0.229^{* * *} \\
(0.043) \\
-1.282^{*} \\
(0.770) \\
0.419^{*} \\
(0.214) \\
-12.441^{* * *} \\
(3.641) \\
2.156 * * \\
(1.052) \\
-0.035 \\
(0.203) \\
-0.048 \\
(0.295) \\
0.309 \\
(0.383) \\
0.853^{* *} \\
(0.380) \\
-0.596 \\
(0.634) \\
-5.651 \\
(3.485) \\
185.530^{* * *} \\
(56.31)
\end{gathered}
$$$$
\text { (56.317) }
$$

Observations

No of banks

No of instruments

AR-2

Hansen J

\section{1}

129

89

0.395

0.640
(2)

Members of foreign financial groups

Robust standard errors in parentheses; *** $\mathrm{p}<0.01,{ }^{* *} \mathrm{p}<0.05, * \mathrm{p}<0.1$;

The estimation method employed here is the System GMM Arellano-Bover/Blundell-Bond estimator. 'AR-2' is the p-value of the Arellano - Bond test. The $\mathrm{H} 0$ is that the average autocovariance in the residuals is of order 3. 'Hansen J' is the p-value of the Hansen J test for overidentifying restrictions, which is asymptotically distributed as chi2 under the null of instrument validity. Economic Capital is the ratio of equity to total assets. Liquidity is the ratio of liquid assets to total assets. Size is the natural logarithm of total assets. Loan Impairments is the ratio of loan impairment charges to gross loans. Deposit ratio is the ratio of customer deposits to total funding. Global financial crisis is a dummy for year 2008; All ratios are expressed in \%.

At the presence of cross-sectional dependence in the disturbances, the employment of many conventional panel estimators produces inconsistent estimations and misleading inferences (Chudik \& Pesaran, 2013). Especially as the cross-sectional dimension (N) grows large for a fixed number of years $(\mathrm{T})$, the generalized method of moments (GMM) produces inconsistent estimates (Sarafidis \& Robertson, 2009). Unfortunately, it is not possible to implement any of the available tests for cross- 
sectional independence in the current panel data (Sarafidis \& Hoyos, 2006). There are insufficient common observations across the panel to perform them. Nevertheless, the contemporaneous independence assumption should be relaxed. Reports on the modus operandi of financial groups in the region, i.e. Bakker et al (2013), and some limited empirical findings i.e. Jeon et al (2013), De Haas and Van Lelyveld (2010), point in this direction. Once this assumption is removed from the analysis, it must be replaced with others concerning the nature of the dependence between the observations. Those assumptions will point either to a different estimation method, or to a re-estimation of the baseline model with the inclusion of more controls.

The next section reports some auxiliary empirical results, which are guiding the formulation of the subsidiary interdependence assumptions. This study is the first to test empirically those assumptions. A Cross Random effects Model is estimated. This will help testing if there is any resemblance in the credit behavior between members of foreign financial groups. If this holds, then it can be investigated if this resemblance is derived from fixed characteristics of the parent bank or time varying characteristics. Those empirical findings will guide the inclusion of further parent bank variables/controls as well as parent related such as the country of origin of the parent and the macroeconomic conditions in the home country.

\subsection{Second set of Models: controlling for the participation in a specific financial group and year effects}

Results in section 5.1 indicate that belonging to a financial group implies that banks extend credit more than their domestically owned competitors. The question that follows is whether a specific financial group (parent) and its characteristics matter for 
Table 5-6: Crossed Random Effects Models with controls for the parent effect

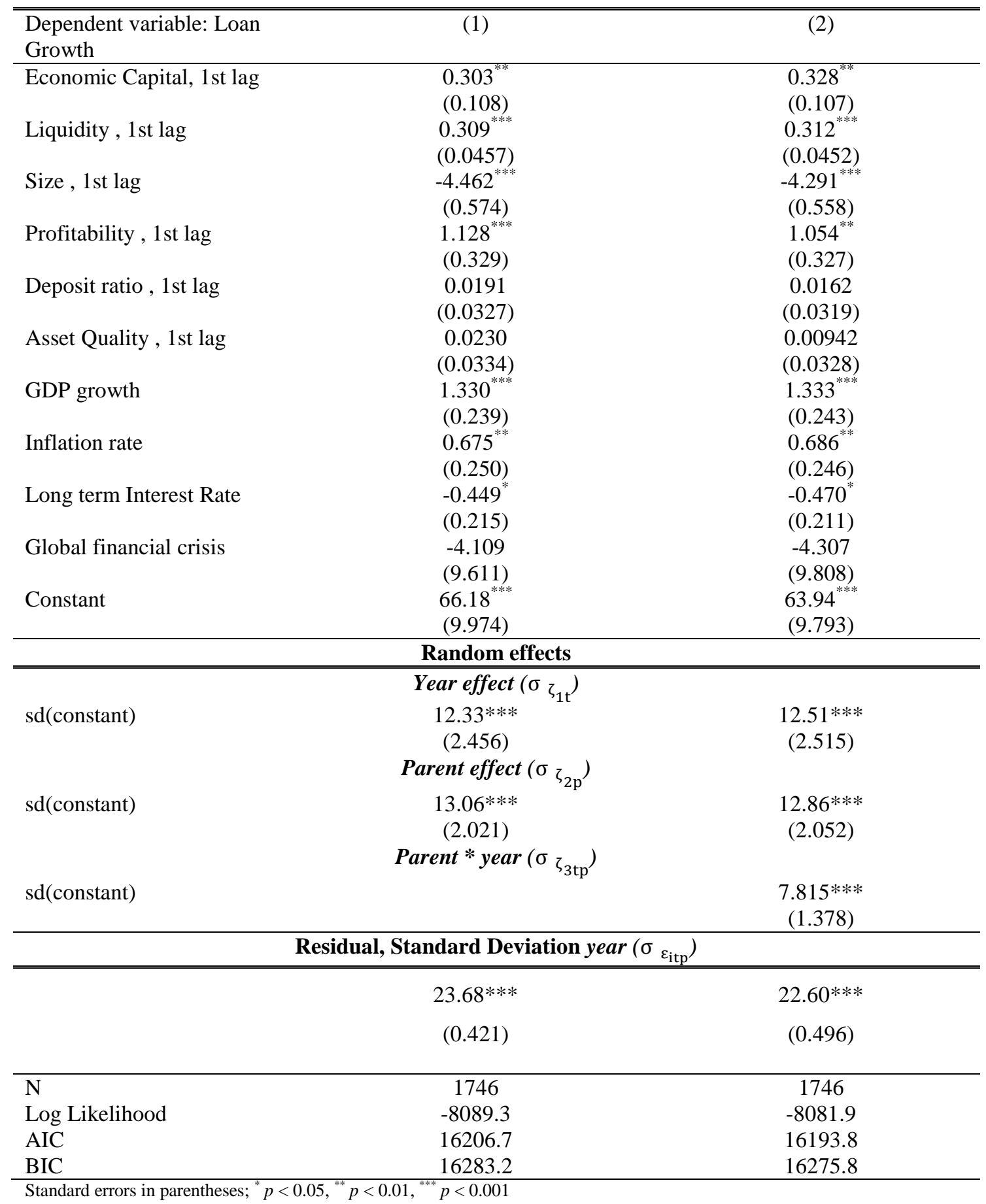

subsidiary's credit growth. In addition, it is tested the changing (or not) nature of this relationship. To do so, Equation (4.2) is estimated, which accounts for time invariant parent level effects and year effects that are common across all banks in the sample Model (1) in Table 5-6. Equation (4.3) is also estimated, that accounts for a parent 
bank-year interaction on top of the effects of Model (1). Therefore, the study allows for changing circumstances to affect differently each parent - Model (2) Table 5-6.

The best model among the two is the one that optimizes the Bayesian \& Akaike information criteria (Burnham \& Anderson, 2004). Model (2) results satisfy these criteria. Moreover a likelihood ratio test indicates that the parent-year interaction should be included in the model ${ }^{16}$.

Liquidity, profitability and economic growth support credit expansion (Table 5-6). Subsidiary's economic capital is positive and significant. The global financial crisis, although with a negative sign, ceases to be significant compared to the results in the previous section. The reason is that its effect is picked up by the random part, where the study has allowed a parent effect and time to bear a different impact upon each parent (i.e. interaction year-parent). The constant represents the average propensity of subsidiaries to extent credit. The random effects component defines by how much subsidiaries deviate from this average. All variances in the random component are significantly different from zero. Specifically $\sigma_{\zeta_{1 \mathrm{t}}} \neq 0$ implies that the average credit growth varies across years. The non-zero estimate for parent $\left(\sigma_{\zeta_{2 p}} \neq 0\right)$ indicates that there is a significant variation in average credit growth across parents. Last but not least, $\sigma_{\zeta_{3 p}} \neq 0$ indicates that the latter variation is time varying.

Table 5-7: Intra-class Correlations based on estimates of Equation (4.3) controlling for the parent effect

$\%$ resemblance between subsidiaries due to:

\begin{tabular}{ll}
\hline a) operating in the same year while belonging to different parents & $17 \%$ \\
b) belonging to the same parent (not time varying parent effect) & $18 \%$ \\
c) belonging to the same parent (allowing for time varying effects) & $42 \%$ \\
\hline
\end{tabular}

${ }^{16}$ The chi2 statisitc is 14.67 and the p-value is 0.0001 
To quantify the relative importance of factors at the parent level, the intra-class correlation statistic is used. According to Table 5-7, differences across years account for $17 \%$ of credit growth variation in the sample. Intra-class correlation of subsidiaries of the same parent and operating during the same year amounts to $42 \%$. This is a high value. It points to a large impact of the parent features on subsidiaries' credit growth. For subsidiaries belonging to the same parent and operating across different years the intra-class correlation drops to $18 \%$. This means that subsidiaries belonging to the same parent over the whole period bear much less resemblance with each other than subsidiaries of the same parent and operating in the same year. This means that time invariant parent specificities are less crucial than their time varying characteristics. As a result, subsidiaries of the same parent resemble very much each other in terms of credit growth within a given year. The majority of the subsidiaries falling into this category are operating in different countries, under different regulatory regimes, face different macroeconomic policies and different market conditions. Still they exhibit a surprising similarity in their credit growth. This is attributed to the fact that they all face the same budget constrains which are imposed at consolidated level and are set by the parent's financial conditions. It is crucial to incorporate this dimension in our dynamic model.

\subsubsection{Host country effect and credit growth}

What follows is a variation of the crossed random effects models, where the parent effect is replaced with the host country effect. The aim is to see how similar are subsidiaries operating in the same country and examine the relative importance of 
country fixed characteristics versus time varying ones. Results are reported in Table 5-8. The two information criteria and a $\log$ likelihood ratio test ${ }^{17}$ indicate that the second model is preferred over the first.

Table 5-8: Crossed Random Effects Models that control for the host country effect

\begin{tabular}{|c|c|c|}
\hline & (1) & (2) \\
\hline \multirow[t]{2}{*}{ Economic Capital, 1st lag } & 0.0543 & 0.0393 \\
\hline & $(0.0955)$ & $(0.0933)$ \\
\hline \multirow[t]{2}{*}{ Liquidity, 1st lag } & $0.303 * * *$ & $0.294 * * *$ \\
\hline & $(0.0441)$ & $(0.0435)$ \\
\hline \multirow[t]{2}{*}{ Size, 1st lag } & $-4.231 * * *$ & $-3.994 * * *$ \\
\hline & $(0.515)$ & $(0.506)$ \\
\hline \multirow[t]{2}{*}{ Profitability, 1st lag } & $1.033 * *$ & $0.865 * *$ \\
\hline & $(0.335)$ & $(0.328)$ \\
\hline \multirow{2}{*}{ Deposit rate, 1st lag } & -0.00104 & -0.0132 \\
\hline & $(0.0306)$ & $(0.0296)$ \\
\hline \multirow[t]{2}{*}{ Loan Impairments, 1st lag } & 0.0503 & $0.0704 *$ \\
\hline & $(0.0342)$ & $(0.0330)$ \\
\hline \multirow[t]{2}{*}{ GDP growth } & $1.331 * * *$ & $1.388 * * *$ \\
\hline & $(0.248)$ & $(0.335)$ \\
\hline \multirow[t]{2}{*}{ Inflation rate } & $0.732 * *$ & $0.861^{*}$ \\
\hline & $(0.272)$ & $(0.344)$ \\
\hline \multirow[t]{2}{*}{ Interest rate } & $-0.598 *$ & -0.494 \\
\hline & $(0.237)$ & $(0.291)$ \\
\hline \multirow[t]{2}{*}{ Global financial crisis } & -5.018 & -5.297 \\
\hline & $(9.612)$ & $(10.21)$ \\
\hline \multirow[t]{2}{*}{ Constant } & $67.95 * * *$ & $64.77 * * *$ \\
\hline & $(9.182)$ & $(9.290)$ \\
\hline \multicolumn{3}{|c|}{ Year effect } \\
\hline \multirow[t]{2}{*}{ sd(constant) } & $12.31 * * *$ & $12.76 * * *$ \\
\hline & $(2.458)$ & $(2.656)$ \\
\hline \multirow{3}{*}{$\operatorname{sd}($ constant $)$} & y effect & \\
\hline & $2.536^{*}$ & $0.000000385^{*}$ \\
\hline & $(0.941)$ & $(0.00000255)$ \\
\hline \multirow[b]{2}{*}{ sd(constant) } & Country & \\
\hline & & $\begin{array}{l}12.95 * * * \\
(2.000)\end{array}$ \\
\hline \multicolumn{3}{|c|}{ Residual, Standard Deviation } \\
\hline & $24.77 * * *$ & $23.05 * * *$ \\
\hline & $(0.423)$ & $(0.434)$ \\
\hline $\mathrm{N}$ & 1747 & 1747 \\
\hline Log Likelihood & -8115.8 & -8080.5 \\
\hline AIC & 16259.7 & 16190.9 \\
\hline BIC & 16336.2 & 16272.9 \\
\hline \multicolumn{3}{|c|}{$\begin{array}{l}\text { Standard errors in parentheses } \\
{ }^{*} p<0.05,{ }^{* *} p<0.01,{ }^{* * *} p<0.001\end{array}$} \\
\hline
\end{tabular}


The magnitude and significance of the estimates combined with the intra-class correlation statistics in Table 5-9, indicate that time invariant host country effects can be ignored, while time varying are statistically relevant. Such a result can be attributed to the fact that those countries are still in a transitory period, with a still changing institutional, legislative and regulatory frameworks. Their economic situation seems to vary across the years thus impacting on credit growth.

Table 5-9 Intra-class Correlations based on estimates of Equation (4.3) controlling for the host country effect

\% resemblance between subsidiaries due to:

a) operating in the same year and in different countries $18 \%$

b) operating in the same country across different years $0 \%$

c) operating in the same year and in the same country $38 \%$

Subsidiaries operating in the same host country and during the same year resemble each other by $38 \%$ in the way they extent credit. Parents seem to have similar expectations about the prospects of each country, which causes subsidiaries in each country to behave much alike. Moreover subsidiaries operating in the same country and across different years bear absolutely no similarity (0\%, Table 5-9), while banks belonging to the same financial group across different years resemble each other by $18 \%$ (Table 5-7). Therefore it is crucial to address the parent - subsidiary relationship. It is also important to control for country specific time varying effects at the host country level.

\subsubsection{Financial group's country of origin as a determinant for credit growth}


Table 5-10: Crossed Random Effects Models, with controls for the home country and the parent effect

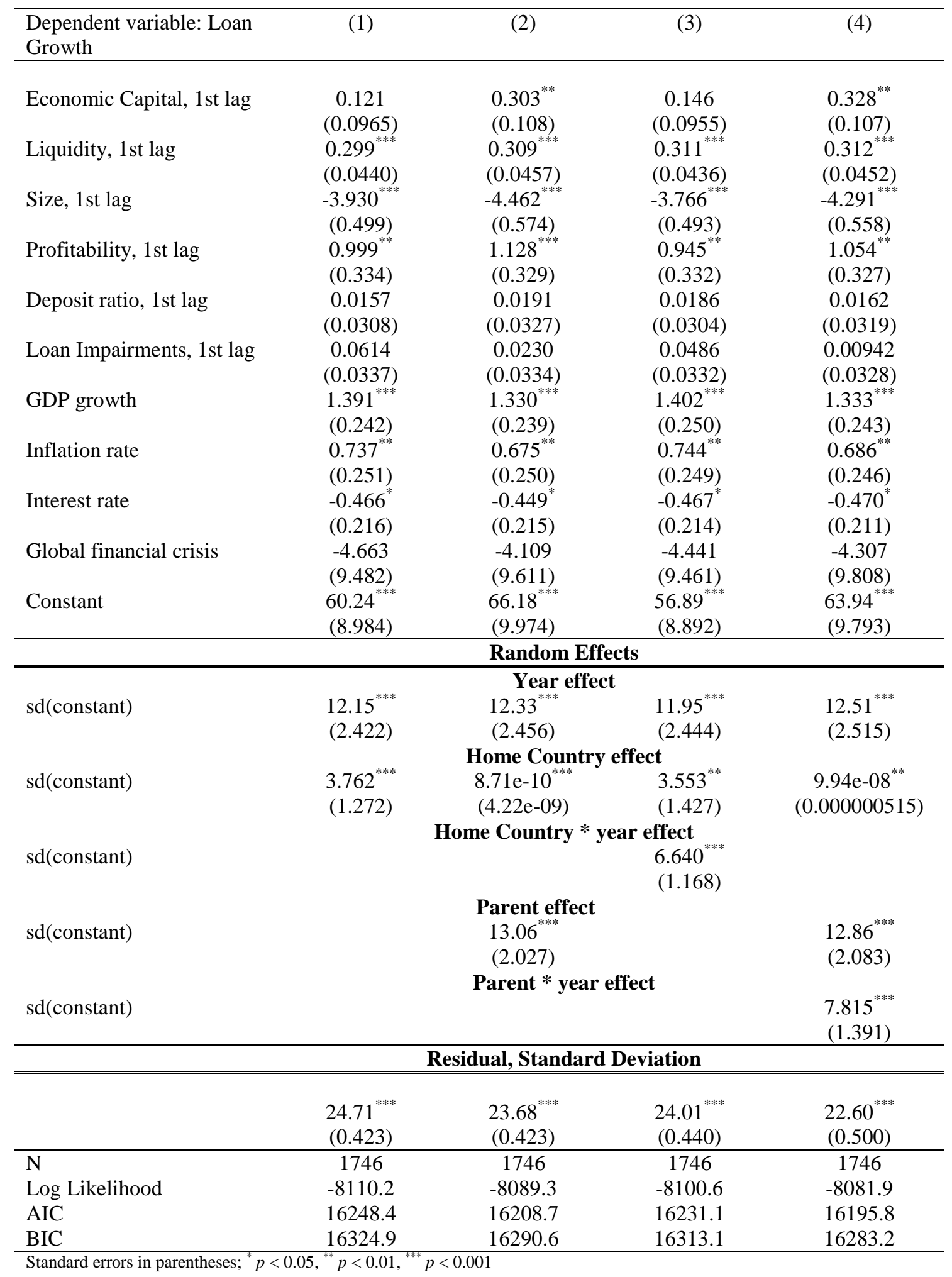


In this paragraph it is investigated the effect of the home country on subsidiaries' credit growth. Equation (4.2) and Equation (4.3) are slightly amended, by introducing an extra level: home country.

Parent banks have a single home country across their whole history in the sample therefore parents are treated as nested within their home countries. In the random component the study gradually introduces several effects (Table 5-10). Model (1) includes a crossed random effect of time and a crossed home country effect. Model (2) includes a crossed random effect of time, a crossed home country effect and a random effect of parent, which is nested within home country. In models (3) and (4) the above estimations are repeated and also allow for an interaction between time and either home country or financial group. Results (Table 5-10) indicate that, once the parent effect is added, the variance at the home country level remains significant but it approaches zero. Therefore, the home country effect can be ignored and the analysis can focus on the level of parent banks.

\subsection{Parent bank fundamentals and credit growth}

Table 5-11 presents the baseline results for the determinants of foreign bank lending in CESEE countries during the years 2000-2014. Models include controls for parents' financial characteristics and macroeconomic conditions of the parents' home country.

Lagged credit growth is found to have a persistent effect on today's outcomes. However the global financial crisis of 2008 clearly brought about a large negative effect. Economic growth both at the host country and the home country level has a 
Table 5-11: Determinants of subsidiaries credit extensions - including parent banks' characteristics

\begin{tabular}{|c|c|c|c|}
\hline $\begin{array}{l}\text { Dependent variable: } \\
\text { Loan Growth }\end{array}$ & $\begin{array}{l}\text { (1) } \\
\mathrm{FE}\end{array}$ & $\begin{array}{c}(2) \\
\text { sys GMM } \\
\end{array}$ & $\begin{array}{c}(3) \\
\text { diff GMM } \\
\end{array}$ \\
\hline Loan growth, 1st lag & $\begin{array}{l}0.134 * * * \\
(0.039)\end{array}$ & $\begin{array}{l}0.226 * * * \\
(0.042)\end{array}$ & $\begin{array}{l}0.151 * * * \\
(0.037)\end{array}$ \\
\hline Economic Capital, 1st lag & $\begin{array}{c}0.232 \\
(0.220)\end{array}$ & $\begin{array}{c}0.094 \\
(0.252)\end{array}$ & $\begin{array}{c}0.398 \\
(0.287)\end{array}$ \\
\hline Liquidity, 1st lag & $\begin{array}{c}0.427 * * * \\
(0.094)\end{array}$ & $\begin{array}{c}0.601 * * * \\
(0.090)\end{array}$ & $\begin{array}{c}0.317 * * * \\
(0.089)\end{array}$ \\
\hline Size, 1st lag & $\begin{array}{c}-17.870 * * * \\
(1.647)\end{array}$ & $\begin{array}{c}-6.285^{* * * *} \\
(1.236)\end{array}$ & $\begin{array}{c}-12.090 * * * \\
(2.619)\end{array}$ \\
\hline Profitability, 1st lag & $\begin{array}{c}1.158^{*} \\
(0.598)\end{array}$ & $\begin{array}{c}1.141 \\
(0.723)\end{array}$ & $\begin{array}{c}0.041 \\
(0.704)\end{array}$ \\
\hline Deposit ratio, 1st lag & $\begin{array}{l}-0.053 \\
(0.054)\end{array}$ & $\begin{array}{l}-0.119 \\
(0.083)\end{array}$ & $\begin{array}{c}-0.234 * * \\
(0.111)\end{array}$ \\
\hline Loan Impairments, 1st lag & $\begin{array}{c}-0.151 * * * \\
(0.051)\end{array}$ & $\begin{array}{l}-0.041 \\
(0.052)\end{array}$ & $\begin{array}{c}-0.168 * * * \\
(0.057)\end{array}$ \\
\hline GDP growth & $\begin{array}{c}0.995 * * * \\
(0.203)\end{array}$ & $\begin{array}{c}1.019 * * * \\
(0.251)\end{array}$ & $\begin{array}{c}0.914 * * * \\
(0.237)\end{array}$ \\
\hline Inflation rate & $\begin{array}{c}0.306 \\
(0.314)\end{array}$ & $\begin{array}{c}0.416 \\
(0.258)\end{array}$ & $\begin{array}{c}0.051 \\
(0.358)\end{array}$ \\
\hline Interest rate & $\begin{array}{c}-0.736 * * \\
(0.369)\end{array}$ & $\begin{array}{c}-0.513 * * \\
(0.259)\end{array}$ & $\begin{array}{l}-0.257 \\
(0.390)\end{array}$ \\
\hline Parent: Profitability, 1st lag & $\begin{array}{c}1.131 \\
(0.714)\end{array}$ & $\begin{array}{c}1.263 \\
(0.855)\end{array}$ & $\begin{array}{c}2.540 \\
(1.672)\end{array}$ \\
\hline Parent: Liquidity, 1st lag & $\begin{array}{l}-0.160 \\
(0.104)\end{array}$ & $\begin{array}{l}-0.164 * \\
(0.089)\end{array}$ & $\begin{array}{c}0.245 \\
(0.203)\end{array}$ \\
\hline $\begin{array}{l}\text { Parent: Economic Capital, } \\
\text { 1st lag }\end{array}$ & $-1.028 * *$ & -0.506 & $-3.859 * * *$ \\
\hline Parent: Loan Impairments, & $\begin{array}{c}(0.414) \\
-2.421 * *\end{array}$ & $\begin{array}{c}(0.475) \\
-2.955 * * *\end{array}$ & $\begin{array}{c}(0.990) \\
-9.836^{* * * *}\end{array}$ \\
\hline & $(\mathbf{1 . 0 3 2})$ & $(0.879)$ & (2.329) \\
\hline Global financial crisis & $\begin{array}{l}-0.599 \\
(2.336)\end{array}$ & $\begin{array}{c}-7.420 * * * \\
(2.135)\end{array}$ & $\begin{array}{c}-9.241 * * * \\
(2.477)\end{array}$ \\
\hline Home country: GDP growth & $\begin{array}{c}0.790 * * * \\
(0.269)\end{array}$ & $\begin{array}{c}0.699 * * \\
(0.323)\end{array}$ & $\begin{array}{c}0.364 \\
(0.369)\end{array}$ \\
\hline Home country Inflation rate & $\begin{array}{l}-0.613 \\
(0.564)\end{array}$ & $\begin{array}{c}-1.090 * * \\
(0.454)\end{array}$ & $\begin{array}{l}-0.639 \\
(0.519)\end{array}$ \\
\hline Constant & $\begin{array}{l}275.606 * * * \\
\quad(25.609)\end{array}$ & $\begin{array}{l}105.421 * * * \\
(21.105)\end{array}$ & \\
\hline Observations & 1,568 & 1,568 & 1,355 \\
\hline R-squared & 0.496 & & \\
\hline No of banks & 193 & 193 & 181 \\
\hline No of instruments & & 185 & 177 \\
\hline AR-2 & & 0.817 & 0.458 \\
\hline Hansen $\mathbf{J}$ & & 0.230 & 0.261 \\
\hline
\end{tabular}

Robust standard errors in parentheses; *** $\mathrm{p}<0.01, * * \mathrm{p}<0.05, * \mathrm{p}<0.1 ; \mathrm{FE}$ refers to panel estimation controlling for individual bank fixed effects with robust standard errors. sys GMM refers to estimation using the Arellano-Bover/Blundell-Bond estimator. diff GMM refers to estimation using the Arellano - Bond difference panel data estimator with robust standard errors.'AR-2' is the p-value of the Arellano - Bond test. The $\mathrm{H} 0$ is that the average autocovariance in the residuals is of order 2. 'Hansen J' is the p-value of the Hansen $J$ test for overidentifying restrictions, which is asymptotically distributed as chi2 under the null of instrument validity. Economic Capital is the ratio of equity to total assets. Liquidity is the ratio of liquid assets to total assets. Size is the natural logarithm of total assets. Loan Impairments is the ratio of loan impairment charges to gross loans. Deposit ratio is the ratio of customer deposits to total funding. Global financial crisis is a dummy for year 2008; All ratios are expressed in \%. 
significant and positive effect. Interest rates at the home country level are also significant with a negative sign thus reflecting a transmission channel of lending costs from the home to the host economy.

Large subsidiaries exhibit lower credit growth rates on average. Subsidiaries' profitability has been found significant in only one out of the three estimation methods. Therefore subsidiaries do not fund their growth through their own profits. This indicates a longer-term expansion strategy of parents in the region, whereby current profitability at the domestic level is a secondary parameter. This is not a surprising result, as it has been documented in previous empirical literature, Cull and Martinez (2013) and Haas and Lelyveld (2006).

Subsidiary's funding structure, namely deposit rate, is also found irrelevant for its credit growth, in line with Cull and Martinez (2013). Once it has been found significant with a negative sign, therefore the higher the deposit rate the slower the credit growth. Foreign subsidiaries did not rely heavily on local deposits as a source of funding for their credit expansion. Also subsidiaries expand credit irrespectively of their capital ratio. This result must be seen in comparison with parents' economic capital, which is significant and negative in two out of the three model estimations. Consequently, what constrains subsidiaries credit growth is parent capital position rather their own domestic capital position. This is an indication of a rather centralized management of capital levels within Groups. These findings contrast De Haas and Lelyveld (2006; 2010). They found capital ratios at subsidiary level significant but for a wider set of countries and they did not control for parent bank's capital rate. Yet, current findings are in line with Cull and Martinez (2013) which includes models 
based on our geographical region of interest. Subsidiary's liquidity is consistently significant and positive. On the other hand, parent liquidity is found significant only once and with a negative sign. Therefore, on top of capital ratio, parent liquidity acts also as a constraint for subsidiary's credit growth. The direction of this effect is in line with parents offering support to their subsidiaries. It is an indication of parents issuing loans to their subsidiaries, in order to boost subsidiaries' liquidity, at the expense of their liquid assets position (e.g. cash and government securities).

The results on liquidity constraints at the parent bank level are in line with De Haas and Van Lelyveld (2010). The latter study also finds subsidiary liquidity to be relevant. When parents decide a conservative policy and resort to withholding more liquid assets, credit growth at the subsidiary level declines. When parents decide to reduce their own liquidity positions they pass-on more liquid assets to their subsidiaries (e.g. granting of intragroup loans). This in turns transforms into credit growth in the host country.

Parents' asset quality is a relevant determinant of credit growth at subsidiary level. Specifically this variable is the rate of loan impairment charges to total loans. This is consistently significant across models. Loan impairment charges are also at subsidiary level significant. Loan impairments are the result of the project screening intelligence at consolidated level. The global financial crisis determined losses for banks and a deterioration of their loan portfolio. It could be argued that loan impairments are capturing the effect of time and of the crisis. To control for this, the model is reestimated model including year dummies (Table 5-12 columns 1, 2 and 4). Moreover for robustness country dummies are also included (Table 5-12, columns 3 and 4). As a 
Table 5-12: Determinants of subsidiaries credit extensions - including parent banks' fundamentals and controlling for year fixed effects and host country fixed effects

\begin{tabular}{|c|c|c|c|c|}
\hline $\begin{array}{l}\text { Dependent variable: } \\
\text { Loan Growth }\end{array}$ & $\begin{array}{l}\text { (1) } \\
\text { sys GMM }\end{array}$ & $\begin{array}{l}\text { (2) } \\
\text { diff GMM }\end{array}$ & $\begin{array}{l}(3) \\
\text { sys GMM }\end{array}$ & $\begin{array}{l}\text { (4) } \\
\text { sys GMM }\end{array}$ \\
\hline Lagged loan growth, 1st lag & $\begin{array}{l}0.190 * * * \\
(0.053)\end{array}$ & $\begin{array}{l}0.106 * * * \\
(0.040)\end{array}$ & $\begin{array}{l}0.280 * * * \\
(0.050)\end{array}$ & $\begin{array}{l}0.200 * * * \\
(0.051)\end{array}$ \\
\hline Economic Capital, 1st lag & $\begin{array}{l}0.281 \\
(0.333)\end{array}$ & $\begin{array}{l}-0.031 \\
(0.310)\end{array}$ & $\begin{array}{l}-0.221 \\
(0.291)\end{array}$ & $\begin{array}{l}0.116 \\
(0.367)\end{array}$ \\
\hline Liquidity, 1st lag & $\begin{array}{l}0.296 * * \\
(0.124)\end{array}$ & $\begin{array}{l}0.442 * * * \\
(0.098)\end{array}$ & $\begin{array}{l}0.520 * * * \\
(0.125)\end{array}$ & $\begin{array}{l}0.288 * * \\
(0.120)\end{array}$ \\
\hline Size, 1st lag & $\begin{array}{l}-5.929 * * * \\
(2.248)\end{array}$ & $\begin{array}{l}-24.221 * * * \\
(7.636)\end{array}$ & $\begin{array}{l}-10.046^{* * * *} \\
(1.806)\end{array}$ & $\begin{array}{l}-6.388 * * \\
(3.132)\end{array}$ \\
\hline Profitability, 1st lag & $\begin{array}{l}0.105 \\
(0.673)\end{array}$ & $\begin{array}{l}-0.060 \\
(0.429)\end{array}$ & $\begin{array}{l}2.548 * * \\
(1.008)\end{array}$ & $\begin{array}{l}0.052 \\
(0.675)\end{array}$ \\
\hline Deposit ratio, 1st lag & $\begin{array}{l}0.032 \\
(0.086)\end{array}$ & $\begin{array}{l}-0.081 \\
(0.111)\end{array}$ & $\begin{array}{l}0.036 \\
(0.096)\end{array}$ & $\begin{array}{l}0.011 \\
(0.084)\end{array}$ \\
\hline Loan Impairments, 1st lag & $\begin{array}{l}-0.098 * \\
(0.051)\end{array}$ & $\begin{array}{l}-0.148 * * \\
(0.060)\end{array}$ & $\begin{array}{l}-0.256 * * \\
(0.114)\end{array}$ & $\begin{array}{l}-0.098 * * \\
(0.049)\end{array}$ \\
\hline GDP growth & $\begin{array}{l}0.467 \\
(0.306)\end{array}$ & $\begin{array}{l}0.269 \\
(0.337)\end{array}$ & $\begin{array}{l}0.676 * * * \\
(0.239)\end{array}$ & $\begin{array}{l}0.594 * * \\
(0.273)\end{array}$ \\
\hline Inflation rate & $\begin{array}{l}0.281 \\
(0.268)\end{array}$ & $\begin{array}{l}0.013 \\
(0.408)\end{array}$ & $\begin{array}{l}0.109 \\
(0.299)\end{array}$ & $\begin{array}{l}0.273 \\
(0.300)\end{array}$ \\
\hline Interest rate & $\begin{array}{l}-0.607 * * \\
(0.290)\end{array}$ & $\begin{array}{l}-0.322 \\
(0.384)\end{array}$ & $\begin{array}{l}-0.310 \\
(0.371)\end{array}$ & $\begin{array}{l}-0.318 \\
(0.365)\end{array}$ \\
\hline Parent: Profitability & $\begin{array}{l}0.644 \\
(0.640)\end{array}$ & $\begin{array}{l}-0.571 \\
(1.892)\end{array}$ & $\begin{array}{l}0.542 \\
(0.724)\end{array}$ & $\begin{array}{l}0.241 \\
(0.566)\end{array}$ \\
\hline Parent: Liquidity & $\begin{array}{l}-0.089 \\
(0.090)\end{array}$ & $\begin{array}{l}-0.198 \\
(0.278)\end{array}$ & $\begin{array}{l}-0.205^{* *} \\
(0.090)\end{array}$ & $\begin{array}{l}-0.088 \\
(0.081)\end{array}$ \\
\hline Parent: Economic Capital & $\begin{array}{l}-0.000 \\
(0.418)\end{array}$ & $\begin{array}{l}-0.931 \\
(1.051)\end{array}$ & $\begin{array}{l}-0.314 \\
(0.403)\end{array}$ & $\begin{array}{l}0.159 \\
(0.402)\end{array}$ \\
\hline Parent: Loan Impairments & $\begin{array}{l}-1.859 * * \\
(0.778)\end{array}$ & $\begin{array}{l}-5.486 * * \\
(2.625)\end{array}$ & $\begin{array}{l}-2.289 * * * \\
(0.856)\end{array}$ & $\begin{array}{l}-1.553 * * \\
(0.777)\end{array}$ \\
\hline Global financial crisis & & & $\begin{array}{l}-7.344 * * * \\
(2.359)\end{array}$ & \\
\hline Home country: GDP growth & $\begin{array}{l}0.625 * * * \\
(0.232)\end{array}$ & $\begin{array}{l}0.758 \\
(0.731)\end{array}$ & $\begin{array}{l}0.761 * * * \\
(0.262)\end{array}$ & $\begin{array}{l}0.650 * * * \\
(0.223)\end{array}$ \\
\hline Home country Inflation rate & $\begin{array}{l}-1.123 * * \\
(0.526)\end{array}$ & $\begin{array}{l}-1.446 * * \\
(0.725)\end{array}$ & $\begin{array}{l}-1.128 * * \\
(0.447)\end{array}$ & $\begin{array}{l}-0.974 * * \\
(0.488)\end{array}$ \\
\hline Constant & $\begin{array}{l}77.660 * \\
(40.696)\end{array}$ & & $\begin{array}{l}138.208 * * * \\
(29.382)\end{array}$ & $\begin{array}{l}82.232 \\
(49.880)\end{array}$ \\
\hline Host Country dummies & $\mathrm{NO}$ & $\mathrm{NO}$ & YES & YES \\
\hline Year Dummies & YES & YES & NO & YES \\
\hline Observations & 1,568 & 1,354 & 1,568 & 1,568 \\
\hline No of banks & 193 & 181 & 193 & 193 \\
\hline No of instruments & 119 & 105 & 187 & 136 \\
\hline AR-2 & 0.229 & 0.938 & 0.918 & 0.231 \\
\hline Hansen J & 0.120 & 0.218 & 0.172 & 0.151 \\
\hline \multicolumn{5}{|c|}{$\begin{array}{l}\text { Robust standard errors in parentheses; *** } \mathrm{p}<0.01, * * \mathrm{p}<0.05, * \mathrm{p}<0.1 \text {; sys GMM refers to estimation using the Arellano- } \\
\text { Bover/Blundell-Bond estimator. diff GMM refers to estimation using the Arellano - Bond difference panel data estimator with } \\
\text { robust standard errors. 'AR-2' is the p-value of the Arellano - Bond test. The H0 is that the average autocovariance in the } \\
\text { residuals is of order 2. 'Hansen } \mathrm{J} \text { ' is the p-value of the Hansen J test for overidentifying restrictions, which is asymptotically } \\
\text { distributed as chi2 under the null of instrument validity. Economic Capital is the ratio of equity to total assets. Liquidity is the } \\
\text { ratio of liquid assets to total assets. Size is the natural logarithm of total assets. Loan Impairments is the ratio of loan impairment } \\
\text { charges to gross loans. Deposit ratio is the ratio of customer deposits to total funding. Global financial crisis is a dummy for year } \\
2008 \text {; All ratios are expressed in \%. }\end{array}$} \\
\hline
\end{tabular}


result, parent health (asset quality) remains consistently significant across the several model specifications and the second most relevant determinant of credit growth. Therefore, the measure of loan impairments and their effect on credit growth captures intrinsic characteristics of parents such as their ability to manage their portfolios and choose to finance profitable projects. At the parent level, liquidity and capital cease to be significant. All other results stay the same with the exception of home country inflation rate, which is a significant negative determinant of credit growth at the subsidiary level.

A second robustness check is run. The sample contains Greek banks with operations in the region. Those banks for some years operate with negative economic capital. At consolidated level they incurred huge losses derived primarily from their home country operations. This extreme case might be driving the results, especially those concerning parent health (asset quality). To account for this effect the models are reestimated excluding Greek banks for the years they operate with negative capital ratio. The results are reported in Table 5-13. Overall the results are the same as above, with parent health remaining an important determinant of credit growth at subsidiary level. An interesting exception is the profitability of the parents, which turns significant. On the other hand subsidiaries' profitability is only partially significant. Consequently, those parents not facing extreme adverse conditions sustain credit growth through their own profitability and transfer of resources to the subsidiaries.

The third set of robustness checks tests the effect generated by the inclusion of relatively large subsidiaries into the sample, whereby the subsidiary size is defined in relation to parent bank balance sheet. Following previous literature (De Haas and Van 
Lelyveld, 2010; Jeon et al., 2013) endogeneity issues have been precluded because the average subsidiary balance sheet is significantly smaller than its parent bank balance sheet in the database. If a subsidiary is small relative to the parent bank, the omitted

Table 5-13: Subsidiaries' credit growth - including parent banks' fundamentals, home country macro and excluding subsidiaries with parent banks operating with negative capital ratio

\begin{tabular}{|c|c|c|c|c|c|}
\hline Dependent variable: & (1) & (2) & (3) & (4) & (5) \\
\hline Loan Growth & $\mathrm{FE}$ & sys GMM & diff GMM & sys GMM & sys GMM \\
\hline \multirow[t]{2}{*}{ Loan growth } & $0.133 * * *$ & $0.223 * * *$ & $0.145 * * *$ & $0.219 * * *$ & $0.288 * * *$ \\
\hline & $(0.039)$ & $(0.041)$ & $(0.038)$ & $(0.043)$ & $(0.047)$ \\
\hline \multirow[t]{2}{*}{ Economic Capital } & 0.226 & 0.008 & 0.344 & 0.202 & -0.322 \\
\hline & $(0.220)$ & $(0.244)$ & $(0.309)$ & $(0.232)$ & $(0.268)$ \\
\hline \multirow[t]{2}{*}{ Liquidity } & $0.421 * * *$ & $0.569 * * *$ & $0.269 * * *$ & $0.494 * * *$ & $0.508 * * *$ \\
\hline & (0.094) & $(0.095)$ & (0.091) & $(0.121)$ & $(0.126)$ \\
\hline \multirow[t]{2}{*}{ Size } & $-17.716^{* * *}$ & $-6.341 * * *$ & $-11.461 * * *$ & $-2.822 * *$ & $-9.396^{* * *}$ \\
\hline & (1.637) & $(1.247)$ & (2.794) & $(1.133)$ & $(1.638)$ \\
\hline \multirow[t]{2}{*}{ Profitability } & $1.047 *$ & 0.916 & -0.025 & 0.063 & $1.960 * *$ \\
\hline & $(0.595)$ & $(0.701)$ & $(0.602)$ & $(0.622)$ & $(0.993)$ \\
\hline \multirow[t]{2}{*}{ Deposit ratio } & -0.056 & $-0.140 *$ & $-0.239 * *$ & 0.010 & 0.024 \\
\hline & $(0.054)$ & $(0.079)$ & $(0.108)$ & $(0.078)$ & $(0.093)$ \\
\hline \multirow[t]{2}{*}{ Loan Impairments } & $-0.157 * * *$ & -0.051 & $-0.159 * * *$ & -0.042 & $-0.260 * *$ \\
\hline & $(0.050)$ & $(0.046)$ & $(0.057)$ & $(0.047)$ & $(0.108)$ \\
\hline \multirow[t]{2}{*}{ GDP growth } & $0.905 * * *$ & $0.989 * * *$ & $0.898 * * *$ & $0.740 * *$ & $0.623 * * *$ \\
\hline & $(0.205)$ & $(0.254)$ & $(0.247)$ & $(0.290)$ & $(0.229)$ \\
\hline \multirow[t]{2}{*}{ Inflation rate } & 0.314 & 0.372 & 0.199 & 0.324 & 0.151 \\
\hline & $(0.311)$ & $(0.258)$ & $(0.372)$ & $(0.252)$ & $(0.287)$ \\
\hline \multirow{2}{*}{ Interest rate } & $-0.740 * *$ & -0.423 & -0.457 & -0.334 & -0.292 \\
\hline & $(0.371)$ & $(0.258)$ & $(0.470)$ & $(0.256)$ & $(0.367)$ \\
\hline \multirow[t]{2}{*}{ Parent: Profitability } & $3.680 * * *$ & $3.450 * * *$ & $8.405 * * *$ & 1.052 & $2.444 * *$ \\
\hline & $(1.042)$ & $(\mathbf{1 . 0 5 9 )}$ & $(2.146)$ & $(0.856)$ & $(0.999)$ \\
\hline \multirow[t]{2}{*}{ Parent: Liquidity } & -0.121 & $-0.152 *$ & $0.455 * *$ & -0.072 & $-0.173 * *$ \\
\hline & $(0.108)$ & $(0.090)$ & $(0.215)$ & $(0.079)$ & $(0.084)$ \\
\hline \multirow[t]{2}{*}{ Parent: Economic Capital } & $-1.186 * * *$ & -0.627 & $-4.535 * * *$ & 0.002 & -0.388 \\
\hline & $(0.421)$ & $(0.424)$ & $(\mathbf{1 . 1 5 4 )}$ & $(0.372)$ & $(0.419)$ \\
\hline \multirow[t]{2}{*}{ Parent: Loan Impairments } & $-1.988 *$ & $-2.974 * * *$ & $-7.323 * * *$ & $-1.901 * *$ & $-2.031 * *$ \\
\hline & $(\mathbf{1 . 0 5 4})$ & $(0.991)$ & $(2.471)$ & $(0.915)$ & $(0.854)$ \\
\hline \multirow[t]{2}{*}{ Global financial crisis } & -1.414 & $-8.454 * * *$ & $-11.591 * * *$ & & $-8.370 * * *$ \\
\hline & $(2.386)$ & $(2.048)$ & $(2.852)$ & & $(2.418)$ \\
\hline \multirow[t]{2}{*}{ Home country: GDP growth } & $0.740 * * *$ & $0.543^{*}$ & -0.068 & $0.454 *$ & $0.647 * *$ \\
\hline & $(0.283)$ & $(0.314)$ & $(0.411)$ & $(0.257)$ & $(0.292)$ \\
\hline \multirow[t]{2}{*}{ Home country Inflation rate } & -0.696 & $-1.202 * * *$ & $-1.093 * *$ & -0.742 & $-1.187 * * *$ \\
\hline & $(0.492)$ & $(0.392)$ & $(0.439)$ & $(0.535)$ & $(0.414)$ \\
\hline \multirow[t]{2}{*}{ Constant } & $273.186^{* * *}$ & $109.731 * * *$ & & $51.588^{* *} *$ & $139.424 * * *$ \\
\hline & $(25.684)$ & $(21.456)$ & & $(20.345)$ & $(25.947)$ \\
\hline Host Country dummies & NO & NO & NO & NO & YES \\
\hline Year Dummies & NO & NO & NO & YES & NO \\
\hline Observations & 1,540 & 1,540 & 1,328 & 1,540 & 1,540 \\
\hline R-squared & 0.495 & & & & \\
\hline No of banks & 193 & 193 & 181 & 193 & 193 \\
\hline No of instruments & & 185 & 177 & 189 & 187 \\
\hline AR-2 & & 0.763 & 0.696 & 0.176 & 0.869 \\
\hline Hansen $\mathbf{J}$ & & 0.245 & 0.196 & 0.323 & 0.189 \\
\hline \multicolumn{6}{|c|}{$\begin{array}{l}\text { Robust standard errors in parentheses; } * * * \mathrm{p}<0.01, * * \mathrm{p}<0.05,{ }^{*} \mathrm{p}<0.1 \text {; FE refers to panel estimation controlling for individua } \\
\text { bank fixed effects with robust standard errors. sys GMM refers to estimation using the Arellano-Bover/Blundell-Bond estimator } \\
\text { diff GMM refers to estimation using the Arellano - Bond difference panel data estimator with robust standard errors. 'AR-2' is the } \\
\text { p-value of the Arellano - Bond test. The H0 is that the average autocovariance in the residuals is of order } 2 \text {. 'Hansen J' is the } \mathrm{p} \\
\text { value of the Hansen J test for overidentifying restrictions, which is asymptotically distributed as chi } 2 \text { under the null of instrumen } \\
\text { validity. Economic Capital is the ratio of equity to total assets. Liquidity is the ratio of liquid assets to total assets. Size is the } \\
\text { natural logarithm of total assets. Loan Impairments is the ratio of loan impairment charges to gross loans. Deposit ratio is the } \\
\text { ratio of customer deposits to total funding. Global financial crisis is a dummy for year } 2008 \text {; all ratios are expressed in \%. }\end{array}$} \\
\hline
\end{tabular}


variable bias is considered to have an immaterial effect on the results. In the study at hand the average subsidiary accounts for about 2.3 per cent of its parent bank's assets, well below the average detected in other previous studies ${ }^{18}$. However, some subsidiaries in the sample have a balance sheet size higher than $10 \%$ of the total balance sheet of the parent bank. These represent roughly $4 \%$ of the total observations in the dataset.

To test for a potential bias introduced by these relatively large subsidiary banks, all subsidiaries with a balance sheet above $10 \%$ of the parent's bank balance sheet have been excluded from the sample. Table 5-14 reports the results. A full reading of the estimation results suggests that the estimation methods and sample are robust, thus confirming by and large the findings.

${ }^{18}$ De Haas and van Lelyveld (2010) have considered an average size of $10 \%$ for a subsidiary as being small enough 
Table 5-14: Subsidiaries' credit growth controlling for parent banks' fundamentals and excluding subsidiaries with assets exceeding $10 \%$ of financial group's total assets

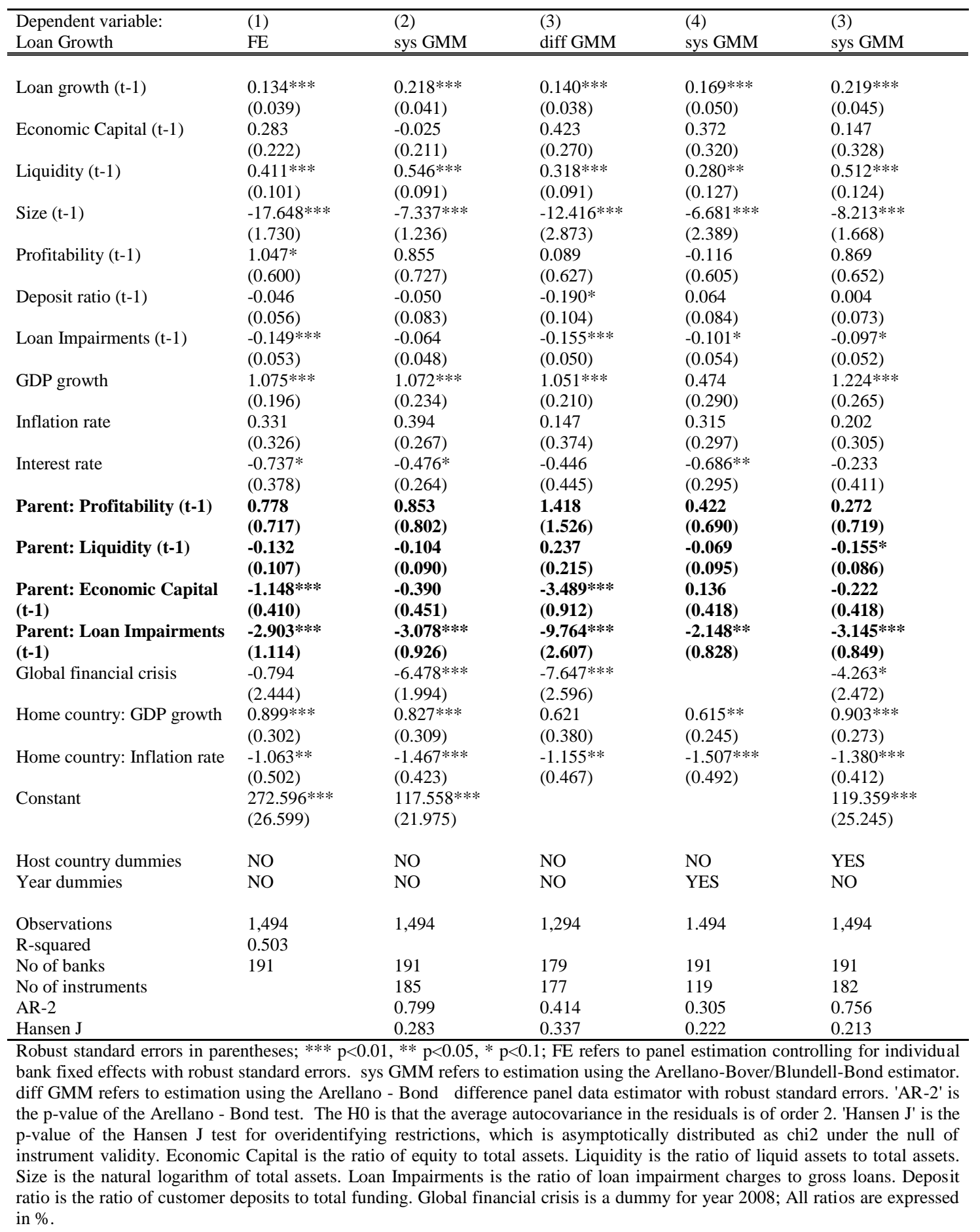




\subsection{The effect of ownership before and after the crisis}

Next, it is investigated if and how the impact of foreign ownership changes after the global financial crisis. Equation (4.1) is estimated for the periods 2000-2007 and 2008-2013 controlling for membership in a financial group and time effects. Results are reported in Table 5-15 (columns 1 to 6).

Before the global financial crisis, subsidiaries consistently expanded credit more than domestic banks. This is the same result for the overall sample. The situation changes after the global financial crisis. On average subsidiaries cease to exhibit any significant difference in their propensity to extent credit compared to domestically owned banks.

The same effect is captured through an alternative modeling approach. Equation (4.1) is estimated across all the years and a new set of variables is added, which is generated by the interaction between a crisis dummy and an ownership variable identifying membership of a bank in an international financial group. The crisis dummy equals 1 for the years 2008-2013 and 0 for all the other years. As a result, there are obtained four categories namely: subsidiary banks before the crisis, domestic banks before the crisis, subsidiary banks after the crisis and domestic banks after the crisis. In columns $7-9$ of Table $5-15^{19}$ the estimated coefficients should be interpreted as a deviation from the baseline of being a domestic bank before the crisis.

Before the crisis subsidiaries boosted local credit growth more than domestic owned banks. However, both groups of banks contributed to a contraction of credit after the

${ }^{19}$ The full set of results is reported in the Appendix, Table D-1. 
crisis. This confirms the previous findings. In addition, the negative reaction of domestic banks was more pronounced than subsidiaries on average. Therefore, there is still detected some sort of divergence in the behavior between domestically owned and foreign owned banks, whereby foreign owned banks (on average) contracted credit less than domestic banks after controlling for macroeconomic and bank balance sheet characteristics.

Table 5-15: Loan growth of members of foreign financial groups vis-à-vis domestic banks before and after crisis

\begin{tabular}{|c|c|c|c|c|c|c|c|c|c|}
\hline \multicolumn{10}{|c|}{ Dependent Variable - Loan Growth of subsidiary $i$} \\
\hline & \multicolumn{3}{|c|}{$\begin{array}{c}\text { Before the } 2008 \text { crisis } \\
(2000-2007) \\
\end{array}$} & \multicolumn{3}{|c|}{$\begin{array}{c}\text { After the } 2008 \text { crisis } \\
(2008-2013)\end{array}$} & \multicolumn{3}{|c|}{$\begin{array}{c}\text { Pooled with pre-post crisis dummies } \\
\text { interacted with ownership }\end{array}$} \\
\hline & (1) & (2) & (3) & (4) & $(5)$ & (6) & (7) & $(8)$ & (9) \\
\hline & & sys & diff & & sys & diff & & sys & diff \\
\hline & FE & GMM & GMM & FE & GMM & GMM & FE & GMM & GMM \\
\hline \multirow{2}{*}{$\begin{array}{l}\text { Subsidiary } \\
\text { bank (owned } \\
\text { by a financial } \\
\text { group) }\end{array}$} & $24.278^{* * *}$ & $8.493 * * *$ & $11.824 * * *$ & -0.219 & 2.374 & -2.299 & & & \\
\hline & (7.349) & (2.548) & (4.435) & (9.083) & (1.691) & (20.254) & & & \\
\hline $\begin{array}{l}\text { Before the } \\
\text { crisis: } \\
\text { subsidiary } \\
\text { bank }\end{array}$ & & & & & & & $\begin{array}{l}23.905 * * * \\
(4.886)\end{array}$ & $\begin{array}{l}9.223 * * * \\
(2.553)\end{array}$ & $\begin{array}{c}15.880 * * * \\
(5.550)\end{array}$ \\
\hline $\begin{array}{l}\text { After the crisis: } \\
\text { domestic bank }\end{array}$ & & & & & & & $\begin{array}{l}-7.205 * * * \\
(2.467)\end{array}$ & $\begin{array}{l}-17.154 * * * \\
\quad(2.632)\end{array}$ & $\begin{array}{c}-19.933 * * * \\
\quad(4.473)\end{array}$ \\
\hline $\begin{array}{l}\text { After the crisis: } \\
\text { subsidiary } \\
\text { bank }\end{array}$ & & & & & & & $\begin{array}{l}8.433 * \\
(5.081)\end{array}$ & $\begin{array}{l}-14.901 * * * \\
(3.065)\end{array}$ & $\begin{array}{c}-12.196^{*} \\
(7.052)\end{array}$ \\
\hline Observations & 1,160 & 1,160 & 1,122 & 1,391 & 1,391 & 1,145 & 2,551 & 2,551 & 2,267 \\
\hline R-squared & 0.301 & & & 0.302 & & & 0.468 & & \\
\hline Banks & 258 & 258 & 245 & 253 & 253 & 237 & 293 & 293 & 275 \\
\hline Instruments & & 146 & 112 & & 186 & 136 & & 279 & 244 \\
\hline AR-3 & & 0.979 & 0.904 & & 0.607 & 0.508 & & 0.709 & 0.816 \\
\hline Hansen J & & 0.409 & 0.377 & & 0.188 & 0.248 & & 0.443 & 0.318 \\
\hline $\begin{array}{l}\text { Robust standard er } \\
\text { (9) include a crisis } \\
\text { sub-period effects. } \\
\text { regressors is omitt } \\
\text { estimator. Differe } \\
\text { the p-value of the } \\
\text { J test for overident } \\
\text { (6) bank character } \\
\text { transformed equat } \\
\text { deviations are app } \\
\text { orthogonal deviatio }\end{array}$ & $\begin{array}{l}\text { ors in parenthe } \\
\text { dummy taking } \\
\text { FE refers to } \\
\text { d as the interes } \\
\text { ce GMM refer } \\
\text { rellano - Bond } \\
\text { fying restrictio } \\
\text { stics are instru } \\
\text { n; in model (8 } \\
\text { ied. Finally, in } \\
\text { ns are applied. }\end{array}$ & $\begin{array}{l}\text { ses; } * * * \mathrm{p}<0 \text {. } \\
\text { value } 1 \text { for ye } \\
\text { anel estimat } \\
\text { is focused or } \\
\text { to estimatio } \\
\text { test. The H0 } \\
\text { ss, which is a } \\
\text { nented with } \\
\text { bank chara } \\
\text { model (9), b }\end{array}$ & $\begin{array}{l}1, * * \mathrm{p}<0.05, \\
\text { ars } 2008-2013 \text {. } \\
\text { on controlling } \\
\text { the pre-post cr } \\
\text { using the Are } \\
\text { s that the aver } \\
\text { ymptotically d } \\
\text { heir third to fi } \\
\text { teristics are in } \\
\text { ink characteris }\end{array}$ & $\begin{array}{l}\mathrm{p}<0.1 ; \mathrm{ye} \\
\text { This dumn } \\
\text { for individ } \\
\text { sis effects. } \\
\text { lano - Bon } \\
\text { ge autocov } \\
\text { stributed a } \\
\text { th lag and } \\
\text { rumented } \\
\text { ics are inst }\end{array}$ & $\begin{array}{l}\mathrm{r} \text { dummies } \\
\text { is interact } \\
\text { al bank fix } \\
\text { ys GMM r } \\
\text { differenc } \\
\text { riance in th } \\
\text { chi2 under } \\
\text { forward o } \\
\text { ith their th }\end{array}$ & $\begin{array}{l}\text { ncluded in e } \\
\text { ed with the f } \\
\text { ed effects w } \\
\text { fers to estim } \\
\text { panel data } \\
\text { residuals is } \\
\text { the null of in } \\
\text { thogonal de } \\
\text { rd to fifth la } \\
\text { th their third }\end{array}$ & $\begin{array}{l}\text { stimations from } \\
\text { nancial group c } \\
\text { ith robust stan } \\
\text { ation using the } \\
\text { stimator with } \mathrm{r} \\
\text { of order } 3 \text {. 'Ha } \\
\text { strument validi } \\
\text { iations are app } \\
\text { and both for } \\
\text { to sixth lag an }\end{array}$ & $\begin{array}{l}\text { (1) to (6); mod } \\
\text { lummy variable } \\
\text { dard errors. Th } \\
\text { Arellano-Bover } \\
\text { obust standard e } \\
\text { tsen } J \text { ' is p-value } \\
\text { ty. In models (2 } \\
\text { lied to the instr } \\
\text { ward and backw } \\
\text { d both forward }\end{array}$ & $\begin{array}{l}\text { ls from (7) to } \\
\text { o generate the } \\
\text { whole set of } \\
\text { Blundell-Bond } \\
\text { rors. 'AR-3' is } \\
\text { of the Hansen } \\
\text { (3), (5) and } \\
\text { aments for the } \\
\text { ard orthogonal } \\
\text { and backward }\end{array}$ \\
\hline
\end{tabular}




\subsection{Direct effects of excessive credit growth on future credit extensions}

Previous empirical studies found a relationship between excessive credit expansion and problem loans. Jiménez \& Saurina (2006) model problem loan ratios as a function of macro- and micro-variables (loan portfolio characteristics). Their sample consists of loans to non-financial firms granted by Spanish banks over the period 1984-2002. They find a robust statistical relationship between rapid credit growth and ex post credit risk measures, suggesting that risks materialize after four years as a consequence of rapid credit growth.

So far, in all estimation results, loan impairment charges at parent level are a significant determinant of subsidiary's credit growth. Higher loan impairment charges consistently deteriorate credit growth at subsidiary level. Loan impairments reflect poor selection of project financing, for instance. If a bank engages into an aggressive expansionary policy, then it might follow more lenient screening standards. If that is the case, then the probability of having financed bad projects increases along with higher loan impairments the years that follow. This determines a decline of credit growth. This channel is investigated, analyzing the effect of past excessive loan growth on current loan growth.

Equation (4.7) is re-estimated adding a variable capturing excessive credit expansion at parent and subsidiary level. This variable is a dummy that equals one if a bank expanded credit more than the yearly average of its peer group, which is set a benchmark. At the parent level, the peer group consists of all international banks that operate in the region in a certain year. 
Table 5-16: The effects of excessive credit growth at parent and subsidiary level

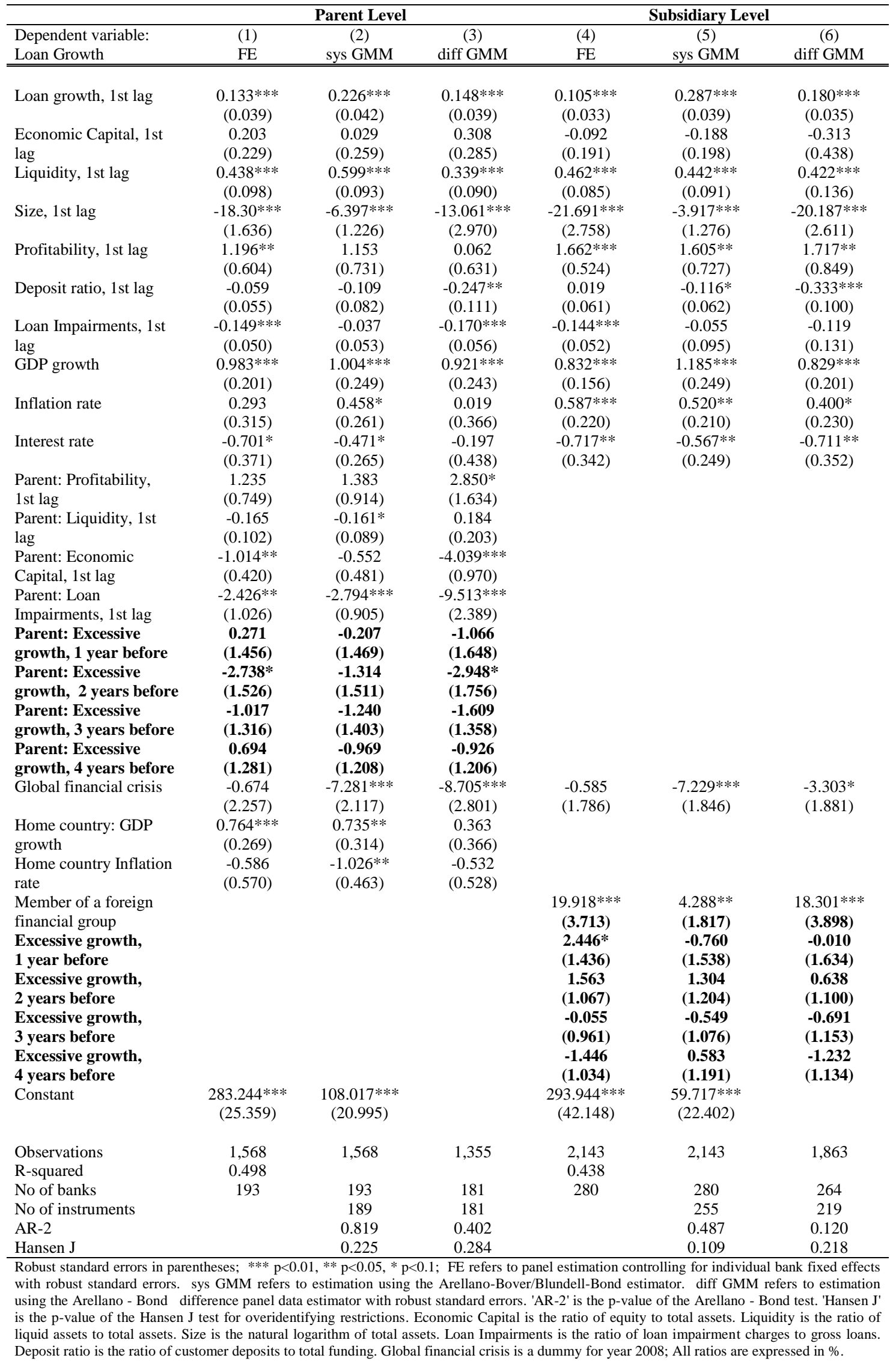


At the subsidiary level, each subsidiary's credit growth is compared with the annual average of all banks operating in the same host country in a given year. This variable is computed accounting for up to four lags following previous literature (Jiménez \& Saurina, 2006).

Results are reported in Table 5-16. Estimations at parent and subsidiary level fail to indicate any connection between past excessive credit growth and current credit growth. This may imply that banks in the region of focus do not necessarily undermine their pre-screening policies when they extend credit aggressively or that excessive credit per se is not an indicator of exuberance in banks' risk taking attitude.

\subsection{Risky attitude and credit growth}

Fabrizio et al (2006) observed that weak banks were expanding credit with the same pace as sound banks, examining credit growth in the region during the years 20012004. The authors point out that prudential risk materializes at later stages and warns of the possible effects of too much risk taking. Theory also predicts that less solvent banks tend to respond to moral hazard incentives by undertaking more portfolio risk, gambling for a jump in future earnings (Marcus, 1984). The sample allows the investigation of the effects of such behavior linking past excessive risk taking to subsequent credit growth.

To do so, a new dummy variable is constructed that combines two elements, namely: excessive credit growth and negatively misaligned capital ratio. The dummy variable equals one if a bank expanded credit more than the annual average of its peer group 
Table 5-17: Excessive risk taking a parent and subsidiary level

\begin{tabular}{|c|c|c|c|c|c|c|}
\hline \multirow{3}{*}{$\begin{array}{l}\text { Dependent variable: } \\
\text { Loan Growth }\end{array}$} & \multicolumn{3}{|c|}{ Parent Level } & \multicolumn{3}{|c|}{ Subsidiary Level } \\
\hline & (1) & $(2)$ & (3) & (4) & $(5)$ & $(6)$ \\
\hline & FE & sys GMM & diff GMM & FE & sys GMM & diff GMM \\
\hline \multirow[t]{2}{*}{ Loan growth, 1st lag } & $0.133 * * *$ & $0.220 * * *$ & $0.145^{* * * *}$ & $0.118 * * *$ & $0.284^{* * * *}$ & $0.422 * * *$ \\
\hline & $(0.040)$ & $(0.042)$ & $(0.039)$ & $(0.030)$ & $(0.034)$ & $(0.061)$ \\
\hline \multirow[t]{2}{*}{ Economic Capital, 1st lag } & 0.230 & 0.106 & 0.348 & -0.072 & $-0.573 * * *$ & 0.010 \\
\hline & $(0.222)$ & $(0.243)$ & $(0.275)$ & $(0.193)$ & $(0.208)$ & $(0.487)$ \\
\hline \multirow[t]{2}{*}{ Liquidity, 1st lag } & $0.427 * * *$ & $0.582 * * *$ & $0.330 * * *$ & $0.448 * * *$ & $0.488 * * *$ & $0.708 * * *$ \\
\hline & $(0.094)$ & $(0.086)$ & $(0.087)$ & $(0.085)$ & $(0.090)$ & $(0.142)$ \\
\hline \multirow[t]{2}{*}{ Size, 1st lag } & $-17.419 * * *$ & $-5.971 * * *$ & $-12.167 * * *$ & $-21.155^{* * * *}$ & $-4.999 * * *$ & $-26.720 * * *$ \\
\hline & (1.704) & $(1.112)$ & $(2.843)$ & (2.759) & $(1.222)$ & (3.313) \\
\hline \multirow[t]{2}{*}{ Profitability, 1st lag } & $1.183 *$ & 1.136 & 0.090 & $1.660 * * *$ & $1.577 * *$ & $2.166^{* * *}$ \\
\hline & $(0.605)$ & $(0.721)$ & $(0.664)$ & $(0.528)$ & $(0.703)$ & $(1.027)$ \\
\hline \multirow[t]{2}{*}{ Deposit ratio, 1st lag } & -0.057 & -0.131 & $-0.247 * *$ & 0.019 & -0.056 & $-0.227 *$ \\
\hline & $(0.055)$ & $(0.085)$ & $(0.113)$ & $(0.061)$ & $(0.066)$ & $(0.127)$ \\
\hline \multirow[t]{2}{*}{ Loan Impairments, 1st lag } & $-0.152 * * *$ & -0.044 & $-0.165^{* * *}$ & $-0.147 * * *$ & -0.098 & $-0.469 * *$ \\
\hline & $(0.049)$ & $(0.050)$ & $(0.060)$ & $(0.053)$ & $(0.098)$ & $(0.229)$ \\
\hline \multirow[t]{2}{*}{ GDP growth } & $1.015^{* * *} *$ & $1.063 * * *$ & $0.948 * * *$ & $0.821 * * *$ & $1.017 * * *$ & $-0.478 *$ \\
\hline & $(0.202)$ & $(0.250)$ & $(0.245)$ & $(0.155)$ & $(0.227)$ & $(0.269)$ \\
\hline \multirow[t]{2}{*}{ Inflation rate } & 0.336 & $0.450 *$ & 0.120 & $0.576^{* * * *}$ & $0.626^{* * *} *$ & -0.043 \\
\hline & $(0.313)$ & $(0.267)$ & $(0.363)$ & $(0.220)$ & $(0.210)$ & $(0.254)$ \\
\hline \multirow[t]{2}{*}{ Interest rate } & $-0.726^{* *}$ & $-0.460 *$ & -0.272 & $-0.725^{* *}$ & $-0.576^{* *}$ & $-1.388 * * *$ \\
\hline & $(0.368)$ & $(0.259)$ & $(0.442)$ & $(0.345)$ & $(0.253)$ & $(0.463)$ \\
\hline \multirow[t]{2}{*}{ Parent: Profitability, 1st lag } & 1.036 & 1.119 & 2.471 & & & \\
\hline & $(0.734)$ & $(0.827)$ & $(1.649)$ & & & \\
\hline Parent: Liquidity, 1st lag & -0.161 & $-0.153^{*}$ & 0.191 & & & \\
\hline & $(0.104)$ & $(0.087)$ & $(0.203)$ & & & \\
\hline Parent: Economic Capital, 1st & $-1.010 * *$ & -0.620 & $-3.691 * * *$ & & & \\
\hline lag & $(0.416)$ & $(0.419)$ & $(0.967)$ & & & \\
\hline Parent: Loan Impairments, $1 \mathrm{st}$ & $-2.432 * *$ & $-2.829 * * *$ & $-9.026^{* * *}$ & & & \\
\hline lag & $(1.046)$ & $(0.884)$ & $(2.324)$ & & & \\
\hline Global financial crisis & -0.930 & $-7.686^{* * *}$ & $-8.623 * * *$ & -0.965 & $-7.674 * * *$ & $-10.815^{* * *}$ \\
\hline & $(2.300)$ & $(2.106)$ & $(2.832)$ & $(1.752)$ & $(1.693)$ & $(2.397)$ \\
\hline Home country: GDP growth & $0.748 * * *$ & $0.645^{* *}$ & 0.353 & & & \\
\hline & $(0.263)$ & $(0.299)$ & $(0.377)$ & & & \\
\hline Home country Inflation rate & -0.562 & $-0.986 * *$ & -0.622 & & & \\
\hline & $(0.590)$ & $(0.432)$ & $(0.516)$ & & & \\
\hline Parent: Risky & 1.655 & 2.369 & 0.059 & & & \\
\hline & (1.647) & (1.551) & $(\mathbf{1 . 6 6 5 )}$ & & & \\
\hline Parent: Risky, 2nd lag & -1.105 & -2.088 & -1.516 & & & \\
\hline & $(1.596)$ & $(\mathbf{1 . 4 9 4 )}$ & $(\mathbf{1 . 6 0 7 )}$ & & & \\
\hline Parent: Risky, 3rd lag & $-2.680 * *$ & $-4.207 * * *$ & $-3.174 * *$ & & & \\
\hline & $(1.352)$ & $(\mathbf{1 . 4 2 4 )}$ & $(1.514)$ & & & \\
\hline Parent: Risky, 4th lag & -0.338 & $-2.266 *$ & -1.080 & & & \\
\hline & (1.270) & $(\mathbf{1 . 3 3 5})$ & (1.373) & & & \\
\hline Member of foreign financial & & & & $19.975 * * *$ & $5.427 * * *$ & $22.918^{* * *}$ \\
\hline group & & & & $(3.794)$ & $(1.882)$ & (4.948) \\
\hline Risky & & & & 1.329 & -1.753 & $-13.651 * * *$ \\
\hline & & & & $(1.442)$ & $(1.532)$ & $(2.276)$ \\
\hline Risky, 2nd lag & & & & $1.963 *$ & 2.186 & $-3.494 * *$ \\
\hline & & & & $(1.168)$ & $(1.381)$ & $(1.702)$ \\
\hline Risky, 3rd lag & & & & -0.378 & -0.690 & $-3.456^{* * *}$ \\
\hline & & & & $(1.128)$ & $(1.327)$ & $(1.324)$ \\
\hline Risky, 4th lag & & & & -1.164 & $-2.329 *$ & 0.849 \\
\hline & & & & (1.188) & $(1.365)$ & $(2.615)$ \\
\hline Constant & $269.643 * * *$ & $103.163 * * *$ & & $286.768 * * *$ & $74.767 * * *$ & \\
\hline & $(26.215)$ & $(19.285)$ & & $(42.424)$ & $(22.100)$ & \\
\hline Observations & 1,568 & 1,568 & 1,355 & 2,143 & 2,143 & 1,861 \\
\hline R-squared & 0.498 & & & 0.437 & & \\
\hline No of banks & 193 & 193 & 181 & 280 & 280 & 264 \\
\hline No of instruments & & 189 & 181 & & 259 & 191 \\
\hline AR-2 & & 0.902 & 0.467 & & 0.434 & 0.604 \\
\hline Hansen $\mathbf{J}$ & & 0.272 & 0.279 & & 0.148 & 0.212 \\
\hline $\begin{array}{l}\text { Robust standard errors in parenthe } \\
\text { with robust standard errors. sys } \\
\text { using the Arellano - Bond differe } \\
\text { that the average autocovariance in } \\
\text { asymptotically distributed as chi } 2 \\
\text { of liquid assets to total assets. Size }\end{array}$ & $\begin{array}{l}* * * \mathrm{p}<0.01, * \\
\mathrm{M} \text { refers to esti } \\
\text { panel data estin } \\
\text { residuals is of } \\
\text { r the null of in } \\
\text { he natural logar }\end{array}$ & $\begin{array}{l}.05, * \mathrm{p}<0.1 \text {; } \\
\text { on using the } \\
\text { with robust } \mathrm{s} \\
2 . \text { 'Hansen } \mathrm{J} \text { ' } \\
\text { ent validity. } \\
\text { of total assets }\end{array}$ & $\begin{array}{l}\text { efers to panel } \\
\text { ano-Bover/Blu } \\
\text { Ird errors. 'AR } \\
\text { p-value of th } \\
\text { omic Capital i } \\
\text { an Impairment }\end{array}$ & $\begin{array}{l}\text { mation controll } \\
\text { ll-Bond estima } \\
\text { the p-value of } \\
\text { nsen } J \text { test for } \\
\text { ratio of equity }\end{array}$ & $\begin{array}{l}\text { for individua } \\
\text { diff GMM } \\
\text { Arellano - B } \\
\text { ridentifying } \mathrm{r} \\
\text { total assets. L }\end{array}$ & $\begin{array}{l}\text { nk fixed effects } \\
\text { s to estimation } \\
\text { test. The H0 is } \\
\text { ctions, which is } \\
\text { dity is the ratio } \\
\text { to gross loans. }\end{array}$ \\
\hline
\end{tabular}


and at the same time the bank had a capital ratio less the annual average of its peer group, where the peers are defined as in section 5.4.1. This variable is constructed both at parent and at subsidiary level.

Results are reported in Table 5-17. Subsidiary level estimates do not produce consistent results across the three models. On the other hand, at the parent level results are more interesting and consistent across the deployed models. Excessive credit expansion combined with a deterioration of the capital ratio always predicts a decline of credit growth in the following periods, after three years specifically. Taking these findings together with the previous results gives us a more complete perspective on the role of parent capital. In all sections above, parents' capital ratio, whenever significant, was found negative. This indicates that subsidiaries owned by better capitalized parents extend less credit on average. Such a narrative however has its limitations. These results help to sharpen the previous findings. Excessive credit growth associated with an excessive decrease in the capital ratio at parent level reduces subsidiaries' capacity to extend credit.

\subsection{Credit growth of foreign banks and the Business cycle}

In most of the case above economic growth has a positive effect on credit growth.

This result remains unaltered either economic growth concerns the host country or the home country of the parent.

Findings concerning the host country are expected, since they are in line with previous empirical literature (Allen et al, 2015; Jeon et al, 2013). Foreign banks play consistently a pro-cyclical role in the host economies. 
However, it is surprising the result concerning home country's growth rate. Growth in the home country benefits credit extensions in the host country. Therefore, parent banks do not view their foreign operations as a substitute to those in their home countries. This contrasts De Haas and Van Lelyveld $(2014 ; 2010)$, which finds that home country's economic growth has a negative impact on subsidiaries' credit growth. According to this study, parent banks trade off lending opportunities between their own country and the countries of operation.

In this strand of literature, none so far has identified the relationship between business cycle and credit growth with the use of direct measures of the business cycle. Instead, they are using measures of macroeconomic variables, with the most prominent one GDP growth. The present study moves a step further, as it captures the business cycle. Following Athanasoglou et al (2008), the business cycle is captured with the HodrickPrescott filter, that calculates deviations of real $\mathrm{GDP}^{20}$ from the trend.

Supposing that foreign banks behave procyclically, when the output gap is positive (GDP exceeds its trend) credit growth should rise too. In a similar manner, when GDP is below trend, credit growth is expected to slow down. The study accounts for asymmetric effects of the business cycle, by splitting the cycle variable into two separate ones. The first one captures positive output gaps. It takes the positive values and if not positive then it equals zero. Similarly it is built a second variable of negative output gap, which equals zero whenever the gap is positive. Estimations are run controlling either for the home country's business cycle or the host country's.

\footnotetext{
${ }^{20}$ Specifically the HP filter is applied on the natural logarithm of the real GDP
} 
Table 5-18: Sensitivity to the Business Cycle

\begin{tabular}{|c|c|c|c|c|c|c|}
\hline \multirow[b]{3}{*}{ VARIABLES } & \multicolumn{3}{|c|}{$\begin{array}{l}\text { Sensitivity to the Cycle of the } \\
\text { host country }\end{array}$} & \multicolumn{3}{|c|}{$\begin{array}{l}\text { Sensitivity to the Cycle of the } \\
\text { home country }\end{array}$} \\
\hline & (1) & (2) & (3) & (4) & (5) & (6) \\
\hline & $\mathrm{FE}$ & sys GMM & diff GMM & $\mathrm{FE}$ & sys GMM & diff GMM \\
\hline Credit growth, 1st lag & $0.093^{* *}$ & $0.205 * * *$ & $0.102 * *$ & $0.093 * *$ & $0.204 * * *$ & $0.120 * * *$ \\
\hline Economic Capital, 1st lag & $0.351^{*}$ & 0.291 & $0.407 *$ & 0.347 & 0.291 & 0.182 \\
\hline & $(0.200)$ & $(0.243)$ & $(0.228)$ & $(0.215)$ & $(0.254)$ & $(0.279)$ \\
\hline Liquidity, 1st lag & $\begin{array}{c}0.439 * * * \\
(0.091)\end{array}$ & $\begin{array}{c}0.611 * * * \\
(0.087)\end{array}$ & $\begin{array}{c}0.322 * * * \\
(0.088)\end{array}$ & $\begin{array}{c}0.440 * * * \\
(0.093)\end{array}$ & $\begin{array}{c}0.617 * * * \\
(0.089)\end{array}$ & $\begin{array}{c}0.463 * * * \\
(0.124)\end{array}$ \\
\hline Size, 1st lag & $\begin{array}{l}-20.641 * * * \\
(1.682)\end{array}$ & $\begin{array}{c}-7.060 * * * \\
(1.240)\end{array}$ & $\begin{array}{l}-17.816^{* * *} \\
(2.870)\end{array}$ & $\begin{array}{l}-21.709^{* * *} \\
(1.643)\end{array}$ & $\begin{array}{l}-7.593 * * * \\
(1.345)\end{array}$ & $\begin{array}{l}-21.252 * * * \\
(2.520)\end{array}$ \\
\hline Profitability, 1st lag & $\begin{array}{l}0.912^{*} \\
(0.529)\end{array}$ & $\begin{array}{c}0.689 \\
(0.650)\end{array}$ & $\begin{array}{l}-0.214 \\
(0.543)\end{array}$ & $\begin{array}{l}0.971^{*} \\
(0.515)\end{array}$ & $\begin{array}{c}0.986 \\
(0.677)\end{array}$ & $\begin{array}{l}0.106 \\
(0.587)\end{array}$ \\
\hline Deposit rate, 1st lag & $\begin{array}{l}-0.016 \\
(0.053)\end{array}$ & $\begin{array}{l}-0.039 \\
(0.078)\end{array}$ & $\begin{array}{l}-0.165^{*} \\
(0.087)\end{array}$ & $\begin{array}{l}-0.023 \\
(0.055)\end{array}$ & $\begin{array}{l}-0.055 \\
(0.086)\end{array}$ & $\begin{array}{c}-0.222 * * \\
(0.092)\end{array}$ \\
\hline Loan Impairments, 1st lag & $\begin{array}{c}-0.160 * * * \\
(0.052)\end{array}$ & $\begin{array}{l}-0.036 \\
(0.050)\end{array}$ & $\begin{array}{l}-0.178 * * * \\
(0.055)\end{array}$ & $\begin{array}{c}-0.171 * * * \\
(0.051)\end{array}$ & $\begin{array}{l}-0.054 \\
(0.048)\end{array}$ & $\begin{array}{c}-0.222 * * * \\
(0.058)\end{array}$ \\
\hline Inflation rate & $\begin{array}{l}-0.446 \\
(0.321)\end{array}$ & $\begin{array}{l}-0.015 \\
(0.248)\end{array}$ & $\begin{array}{l}-0.407 \\
(0.341)\end{array}$ & $\begin{array}{l}-0.438 \\
(0.308)\end{array}$ & $\begin{array}{c}0.003 \\
(0.252)\end{array}$ & $\begin{array}{l}-0.341 \\
(0.320)\end{array}$ \\
\hline Interest rate & $\begin{array}{l}-0.391 \\
(0.318)\end{array}$ & $\begin{array}{l}-0.442^{*} \\
(0.241)\end{array}$ & $\begin{array}{l}-0.191 \\
(0.380)\end{array}$ & $\begin{array}{l}-0.434 \\
(0.321)\end{array}$ & $\begin{array}{l}-0.471^{*} \\
(0.259)\end{array}$ & $\begin{array}{l}-0.446 \\
(0.355)\end{array}$ \\
\hline GDP growth & & & & $\begin{array}{l}-0.187 \\
(0.265)\end{array}$ & $\begin{array}{c}0.361 \\
(0.263)\end{array}$ & $\begin{array}{l}-0.066 \\
(0.282)\end{array}$ \\
\hline Parent: Profitability, 1st lag & $\begin{array}{c}0.730 \\
(0.659)\end{array}$ & $\begin{array}{c}1.030 \\
(0.793)\end{array}$ & $\begin{array}{c}0.723 \\
(1.363)\end{array}$ & $\begin{array}{c}0.813 \\
(0.638)\end{array}$ & $\begin{array}{c}1.123 \\
(0.807)\end{array}$ & $\begin{array}{c}0.948 \\
(0.647)\end{array}$ \\
\hline Parent: Liquidity, 1st lag & $\begin{array}{l}-0.102 \\
(0.100)\end{array}$ & $\begin{array}{l}-0.117 \\
(0.092)\end{array}$ & $\begin{array}{c}0.204 \\
(0.196)\end{array}$ & $\begin{array}{l}-0.100 \\
(0.094)\end{array}$ & $\begin{array}{l}-0.116 \\
(0.102)\end{array}$ & $\begin{array}{l}-0.074 \\
(0.102)\end{array}$ \\
\hline $\begin{array}{l}\text { Parent: Economic Capital, } \\
\text { 1st lag }\end{array}$ & $\begin{array}{l}-0.661^{*} \\
(0.393)\end{array}$ & $\begin{array}{l}-0.452 \\
(0.428)\end{array}$ & $\begin{array}{c}-2.141 * * \\
(0.823)\end{array}$ & $\begin{array}{c}-0.821 * * \\
(0.410)\end{array}$ & $\begin{array}{l}-0.636 \\
(0.457)\end{array}$ & $\begin{array}{c}-0.997 * * \\
(0.420)\end{array}$ \\
\hline $\begin{array}{l}\text { Parent: Loan Impairments, } \\
\text { 1st lag }\end{array}$ & $\begin{array}{c}-1.921 * * \\
(0.827)\end{array}$ & $\begin{array}{c}-3.063 * * * \\
(0.893)\end{array}$ & $\begin{array}{l}-7.354 * * * \\
(2.152)\end{array}$ & $\begin{array}{c}-1.627 * * \\
(0.681)\end{array}$ & $\begin{array}{l}-2.806 * * * \\
(0.800)\end{array}$ & $\begin{array}{c}-1.729 * * \\
(0.753)\end{array}$ \\
\hline Global financial crisis & $\begin{array}{l}-12.308 * * * \\
(1.946)\end{array}$ & $\begin{array}{l}-18.086 * * * \\
(2.121)\end{array}$ & $\begin{array}{l}-17.080 * * * \\
(2.631)\end{array}$ & $\begin{array}{l}-11.049 * * * \\
(2.240)\end{array}$ & $\begin{array}{l}-14.702 * * * \\
(2.075)\end{array}$ & $\begin{array}{c}-11.593 * * * \\
(2.366)\end{array}$ \\
\hline Home country: GDP growth & $\begin{array}{c}0.055 \\
(0.278)\end{array}$ & $\begin{array}{c}0.302 \\
(0.315)\end{array}$ & $\begin{array}{l}-0.169 \\
(0.350)\end{array}$ & & & \\
\hline Home country Inflation rate & $\begin{array}{c}-1.191 * * \\
(0.461)\end{array}$ & $\begin{array}{c}-1.629 * * * \\
(0.389)\end{array}$ & $\begin{array}{l}-1.331 * * * \\
(0.461)\end{array}$ & $\begin{array}{c}-1.264 * * \\
(0.489)\end{array}$ & $\begin{array}{l}-1.668 * * * \\
(0.429)\end{array}$ & $\begin{array}{l}-1.355^{* * *} \\
(0.494)\end{array}$ \\
\hline $\begin{array}{l}\text { Host country: cyclical } \\
\text { output below trend }\end{array}$ & $\begin{array}{c}26.503 \\
(31.538)\end{array}$ & $\begin{array}{l}\text { 118.288**** } \\
(28.997)\end{array}$ & $\begin{array}{c}48.918 \\
(37.604)\end{array}$ & & & \\
\hline $\begin{array}{l}\text { Host country: cyclical } \\
\text { output above trend }\end{array}$ & $\begin{array}{l}\text { 218.816*** } \\
(27.847)\end{array}$ & $\begin{array}{l}132.010 * * * \\
(23.051)\end{array}$ & $\begin{array}{l}197.376 * * * \\
(28.953)\end{array}$ & & & \\
\hline $\begin{array}{l}\text { Home country: cyclical } \\
\text { output below trend }\end{array}$ & & & & $\begin{array}{c}42.281 \\
(32.924)\end{array}$ & $\begin{array}{l}\text { 66.494* } \\
(34.601)\end{array}$ & $\begin{array}{c}39.160 \\
(\mathbf{3 7 . 2 0 4})\end{array}$ \\
\hline $\begin{array}{l}\text { Home country: cyclical } \\
\text { output above trend }\end{array}$ & & & & $\begin{array}{l}212.538 * * * \\
(26.254)\end{array}$ & $\begin{array}{l}\text { 124.718**** } \\
(21.345)\end{array}$ & $\begin{array}{l}198.245 * * * \\
(25.027)\end{array}$ \\
\hline Constant & $\begin{array}{l}310.284 * * * \\
(25.958)\end{array}$ & $\begin{array}{l}114.057 * * * \\
(21.410)\end{array}$ & & $\begin{array}{l}328.780 * * * \\
(25.507)\end{array}$ & $\begin{array}{l}121.756 * * * \\
(23.265)\end{array}$ & \\
\hline Observations & 1,569 & 1,569 & 1,355 & 1,570 & 1,570 & 1,382 \\
\hline R-squared & 0.541 & & & 0.539 & & \\
\hline No of banks & 193 & 193 & 181 & 193 & 193 & 182 \\
\hline No of instruments & & 186 & 178 & & 186 & 178 \\
\hline AR-2 & & 0.953 & 0.414 & & 0.836 & 0.559 \\
\hline Hansen J & & 0.318 & 0.273 & & 0.282 & 0.229 \\
\hline
\end{tabular}

Robust standard errors in parentheses; $* * * p<0.01, * * \mathrm{p}<0.05, * \mathrm{p}<0.1 ; \mathrm{FE}$ refers to panel estimation controlling for individual bank fixed effects with robust standard errors. Sys GMM refers to estimation using the Arellano-Bover/Blundell-Bond estimator. Difference GMM refers to estimation using the Arellano - Bond difference panel data estimator with robust standard errors. 'AR-2' is the p-value of the Arellano - Bond test. The $\mathrm{H} 0$ is that the average autocovariance in the residuals is of order 2. 'Hansen $\mathrm{J}$ ' is the p-value of the Hansen $\mathrm{J}$ test for overidentifying restrictions, which is asymptotically distributed as chi2 under the null of instrument validity.Economic Capital is Equity to total assets. Liquidity is the ratio of liquid assets to total assets. Size is the natural logarithm of total assets. Loan Impairments is the ratio of Loan Impairment charges to gross loans. Deposit rate is the ratio of Customer Deposits to total funding. Global financial crisis is a dummy for year 2008.

All ratios are expressed in \%. 
Results are reported in Table 5-18. Concerning host country's business cycle, foreign banks systematically accelerate economic growth since they respond to positive phases of the cycle. In one out of the three estimation models, but the preferred one, banks seem to respond to negative phases of the cycle too. Foreign banks retreat from the host countries when there is a decline in economic activity there, but at a slight more cautious pace than during upturns. When growth is present, their impulse to increase operations in the host countries is much stronger than their impulse to withdraw from them during economic downturns.

Positive phases of the cycle in the home countries always bear positive spillovers for the host countries. Banks do not view their operations in the region as a substitute of one another. They do not increase their investment in their flourishing home economy at the expense of their foreign operations. On the contrary, when their home economy grows, they place more resources in their operations in CEESE.

On the other hand, when home country's output is below its trend, its influence on subsidiary's credit extensions, if significant, is of the half magnitude compared to periods of growth. Foreign bank operations are somewhat insulated from downswings in the home economies, although they can be affected. 


\section{Chapter 6 Conclusions}

Current research investigates the determinants of credit growth in CESEE accounting for the large presence of foreign banks. Overall, the presence of foreign banks in the CESEE region is judged as beneficial. Parent banks originated from flourishing economies benefit the host countries, through further extensions of credit by their subsidiaries. Indeed, they have contributed to a contraction of credit after the global financial crisis. Yet, their reaction was less pronounced compared with the contraction exercised by domestic banks.

However, subsidiaries credit behavior cannot be viewed in isolation. To the contrary, it needs to be framed into the operating landscape which includes the linkages to foreign entities and their economies. This is the most important contribution of this research to the literature.

In order to investigate the behavior of foreign subsidiaries, dynamic credit growth models were used, controlling also for parent's fundamentals. Lagged credit growth is found to have a persistent effect on today's outcomes. However the global financial crisis of 2008 clearly brought about a large negative effect. Economic growth both at the host country and the home country level has a significant and positive effect. 
Interest rates at the host country level exert a negative impact on credit growth as expected. This suggests that borrowers are more reluctant to demand more debt when interest rates move up. In addition also interest rates at home country level are also significant with a negative sign thus reflecting a transmission channel of lending costs from the home to the host economy. Subsidiaries' size has a negative impact suggesting that large subsidiaries expand their loan portfolio at a slower pace. Higher subsidiaries' liquidity levels have a positive effect on credit growth as expected. Subsidiaries' profitability has been found significant only rarely. Therefore, subsidiaries do not fund their growth through their own profits. This indicates a longer-term expansion strategy of parents in the region, whereby current profitability at the domestic level is a secondary parameter. This is not a surprising result, as it has been documented in previous empirical literature, Cull \& Martinez (2013) and Haas and Lelyveld (2006). Subsidiary's funding structure, namely deposit rate, is also found irrelevant for its credit growth, in line with Cull and Martinez (2013). Also subsidiaries expand credit irrespectively of their capital ratio. Last but not least, parents' asset quality (loan impairment charges) is a relevant determinant of credit growth at subsidiary level. Loan impairment charges are also at subsidiary level significant. Loan impairments are the result of the project screening intelligence at consolidated level. The global financial crisis determined losses for banks and a deterioration of their loan portfolio. The measure of loan impairments and their effect on credit growth capture intrinsic characteristics of parents such as their ability to manage their portfolios and choose to finance profitable projects. Finally, a peer group analysis unveils that risky behaviors at the parent bank level jeopardize future credit extensions at the subsidiary level. Specifically excessive credit expansion and 
reduction of economic capital ratios lead to a decline in subsidiaries' lending capacity in three years' time.

The findings of this study have strategic and policy implications. First, it exhibits that the ownership structure cannot be ignored, given the systemic role of foreign banks in the CESEE region. Second, the performance of subsidiaries is heavily dependent on the composition and quality of the parent banks' balance sheet. Therefore, a consolidated approach should be considered when looking at lending conditions in any of the countries of the CESEE region. Third, negative and positive cross border externalities are fundamental drivers of credit at domestic and regional level. This implies that large players and home country regulators should internalize the direct implications of their strategic decisions on host countries banking sectors and for healthy credit expansions. On the other hand, host country regulators need to consider the natural and intrinsic relevance of elements beyond their control when taking decisions, including parent banks' balance sheet health as well as home countries cyclical position. Therefore, a continuous and open cross border collaboration and coordination between home and host regulators is fundamental for the stability of the regional banking sectors. 


\section{References}

Allen, F., Jackowicz, K., Kowalewski, O., \& Kozłowski, Ł. (2015). Bank lending, crises, and changing ownership structure in Central and Eastern European countries. Journal of Corporate Finance.

Andrianova, S., Baltagi, B., Beck, T., Demetriades, P., Fielding, D., Hall, S., et al. (2015). A new international database on financial fragility, (No. 15/18).

Arellano, M., \& Bover, O. (1995). Another look at the instrumental variable estimation of error-components models. Journal of Econometrics, (68), 29-51.

Athanasoglou, P. P., Brissimis, S. N., \& Delis, M. D. (2008). Bank-specific, industryspecific and macroeconomic determinants of bank profitability. Journal of International Financial Markets, Institutions and Money, 18, 121-136.

Burnham, K. P., \& Anderson, D. R. (2004). Multimodel inference understanding AIC and BIC in model selection. Sociological Methods \& Research, 33 (2), 261-304.

Bakker, B., Klingen, C., Impavido, G., Vandenbussche, J., Zeng, L., \& Yang, J. (2013). Financing Future Growth: The Evolving Role of the Banking System in CESEE: Technical Notes. International Monetary Fund.

Bertay, A. C., Demirgüç-Kunt, A., \& Huizinga, H. (2015). Bank ownership and credit over the business cycle: Is lending by state banks less procyclical? Journal of Banking \& Finance, 50, 326-339. 
Blundell, R., \& Bond, S. (1998). Initial conditions and moment restrictions in dynamic panel data models. Journal of Econometrics, 87 (1), 115-143.

Boyd, J., Levine, R., \& Smith, B. (2001). The impact of inflation on financial sector performance. Journal of Monetary Economics, 47 (2), 221-248.

Brissimis, S. N., \& Delis, M. D. (2009). Identification of a loan supply function: A cross-country test for the existence of a bank lending channel. (Elsevier, Ed.) Journal of International Financial Markets, Institutions and Money, 19(2), 321-335.

Cull, R., \& Martinez Peria, M. S. (2013). Bank ownership and lending patterns during the 2008--2009 financial crisis: evidence from Latin America and Eastern Europe. Journal of Banking \& Finance, 37 (12), 4861-4878.

Cetorelli, N., \& Goldberg, L. S. (2010). Global Banks and International Shock Transmission: Evidence from the Crisis. IMF Economic Review, 59 (1), 41-76.

Chudik, A., \& Pesaran, M. (2013). Large Panel Data Models with Cross-Sectional Dependence: A Survey. CAFE Research Paper, (13.15).

Claessens, S., van Horen, N., Gurcanlar, T., Mercado Sapiain, J., 2008. Foreign Bank Presence in Developing Countries 1995-2006: Data and Trends. SSRN Electronic Journal 42. doi:10.2139/ssrn.1107295

De Haas, R., \& Van Lelyveld, I. (2006). Foreign banks and credit stability in Central and Eastern Europe. A panel data analysis. Journal of Banking \& Finance, 30 (7), 1927-1952.

De Haas, R., \& Van Lelyveld, I. (2010). Internal capital markets and lending by multinational bank subsidiaries. Journal of Financial Intermediation, 19, 1-25. 
De Haas, R., \& Lelyveld, I. (2014). Multinational banks and the global financial crisis: Weathering the perfect storm? Journal of Money, Credit and Banking, 46, 333364.

Dinger, V. (2009). Do foreign-owned banks affect banking system liquidity risk? Journal of Comparative Economics, 37 (4), 647-657.

Fabrizio, S., Igan, D., Mody, A., \& Tamirisa, N. (2006). Czech Republic, Republic of Estonia, Hungary, Republic of Latvia, Republic of Lithuania, Republic of Poland, Slovak Republic, and Republic of Slovenia: Export Structure and Credit Growth. International Monetary Fund.

Flannery, M. J., \& Hankins, K. W. (2013). Estimating dynamic panel models in corporate finance. Journal of Corporate Finance, 1-19.

Hayakawa, K. (2009). First Difference or Forward Orthogonal Deviation- Which Transformation Should be Used in Dynamic Panel Data Models?: A Simulation Study. Economics Bulletin, 29 (3), 2014-2023.

Jeon, B. N., Olivero, M. P., \& Wu, J. (2013). Multinational banking and the international transmission of financial shocks: Evidence from foreign bank subsidiaries. Journal of Banking \& Finance, 37 (3), 952-972.

Jiménez, G., Saurina, J., 2006. Credit Cycles, Credit Risk, and Prudential Regulation. International Journal of Central Banking, 2, 65-98.

Nickell, S. (1981). Biases in dynamic models with fixed effects. Econometrica, 14171426.

Marcus, A. J. (1984). Deregulation and bank financial policy. Journal of Banking \& Finance, 8, 557--565. 
Ongena, S., Peydro, J. L., \& van Horen, N. (2013). Shocks Abroad, Pain at Home? Bank-Firm Level Evidence on the International Transmission of Financial Shocks. DNB Working Papers .

Popov, A., \& Udell, G. F. (2012). Cross-border banking, credit access, and the financial crisis. Journal of International Economics, 87 (1), 147-161.

Sarafidis, V., \& Hoyos, R. E. (2006). On testing for cross sectional dependence in panel data models. Mimeo .

Sarafidis, V., \& Robertson, D. (2009). On the impact of error cross-sectional dependence in short dynamic panel estimation. The Econometrics Journal, 12 (1), 62 81.

Schmider, E., Ziegler, M., Danay, E., Beyer, L., \& Bühner, M. (2010). Is it really robust? Methodology, 6 (4), 147-151.

Sirtaine, S., \& Skamnelos, I. (2007). Credit growth in emerging Europe: a cause for stability concerns? (Vol. 4281). World Bank Publications.

Rabe-Hesketh, S., \& Skrondal, A. (2008). Multilevel and Longitudinal Modeling Using Stata (Second ed.). College station, Texas, United States of America: Stata Press.

Roodman, D. (2006). How to do xtabond2: An introduction to difference and system GMM in Stata. Center for Global Development working paper . 


\section{Appendices}

\section{A. Details on the construction of the sample}

\section{A.1. Ownership}

The study is grounded in a unique dataset of ownership data of the banks in our region. The exact process followed was:

Initially the number of banks in the dataset had to be determined. A list of all commercial, cooperatives and savings banks operating in the region was downloaded from Bankscope along with their basic financials of any account available in the database. This way there were duplicate values for each bank. Next the duplicates were dropped iteratively for a given bank favoring consolidated accounts (Duprey and Le, 2014). This is how someone can get the longest time series possible with each bank appearing only once in our sample. Banks with less than 3 consecutive years in the sample were eliminated. Then market shares were calculated, defining geographically the market at the level of each country. Banks with less than $1 \%$ of Market share were eliminated.

This resulted in a catalogue to banks per country covered by Bankscope. The next step was searching for their ownership over each year for which there are financial data in Bankscope. For this purpose a wide variety of sources were researched, namely Bankscope, Amadeus, financial statements, S\&P IQ capital, Bloomberg, Central bank reports, Ministries' reports, stock exchanges and news. In each case the reliability of the source available was assessed and would determine the number of additional sources one had to look for in order to cross check the data (i.e. audited financial statements would alwayes be considered as superior to data from commercial databases). 


\section{A.2. Imputations}

When constructing the database of characteristics of banks, the aim was to obtain the longest and most uniform possible time series. Bankscope includes data sourced from financial statements based on consolidated and unconsolidated accounting standards. Each accounting standard includes several sub-categories. Bank balance sheet characteristics can be available in one or multiple standards. Moreover the length of the time series varies depending on the accounting standards.

Duprey and Lé (2014) suggest an iterative procedure when dealing with Bankscope data. First the level of consolidation should be chosen. Preference was given to consolidated accounts (e.g. C). Second the available companion data should be employed $\left(\mathrm{C}^{*}\right)$, otherwise an alternative standard of data should be considered to cover for missing data. The growth rate of the companion consolidated accounts $\left(\mathrm{C}^{*}\right)$ was calculated and it was applied to the time series imputing forward and backward the missing values. If this procedure was still leaving some missing values, we checked for the availability of an alternative time series - based on unconsolidated accounts (U) in our case. Ultimately if data gaps were still emerging, those were filled applying the growth rates of companion unconsolidated statements ${ }^{21}\left(\mathrm{U}^{*}\right)$. This procedure removed $^{22}$ the shift effects between one year and another due to the

\footnotetext{
${ }^{21}$ After this last step in the data cleaning processes few breaks were still detected for 19 banks or 31 observations out of 3700 . The missing observations were reconstructed applying a compound growth rate to the available data - Compound annual growth rate $=\frac{\text { Ending Value }}{\text { Beginning Value }^{\frac{1}{\# \text { ofears }}}-1}$

${ }^{22}$ However the employment of unconsolidated data growth rates to extend consolidated data relies on the assumption that a bank maintains the same level of operations over time. A bank may sell part of its operations. Therefore it has no obligation to keep consolidated accounts because the aggregate level of its operations has changed. To avoid this issue it is preferred to apply backdating growth rates based on consolidated accounts to extend unconsolidated data series. Whenever this has led to do more imputations than the number of observations available, were employed growth rates of unconsolidated
} 
employment of different accounting rules, which a data replacement approach would have generated.

\section{A.3. Duplication Issues}

The merger deals of all banks in the sample were checked very carefully. If banks would get absorbed at some point during the period covered, then the exact time that legally the deal came into power was identified. If for any reason the absorbed party would maintain operations as a separate entity for a year after the deal, we would either a) eliminate it or b) use unconsolidated accounts for both entities in the sample.

In many cases banks demonstrated very complicated ownership structures with several intermediate owners. If those owners are included in the sample as individual banks also duplication issues arise, especially whence consolidated accounts are used. For example UniCredit Bank dd in Bosnia Herzegovina has as intermediate owner the Croatian Zagreback Banka which belongs to UniCredit SpA. If one would include consolidated accounts both for the Bosnian and the Croatian Bank, then the Bosnian bank is double counted.

After finalizing the ownership database and having collected all bank identifiers, the merger history of each bank was checked again. Amadeus database was used and checked all merger deals that our banks were involved in, to ascertain no intermediate owner was overlooked. If those intermediate owners concerned the database as individual banks too, then we took extra care of them following the data imputation process.

When doing the imputations we kept track for those intermediate owners what sort of accounts were used as base for the calculations. If consolidated data where used, then we subtracted from those the data of the smallest subsidiary. 


\section{A.4. Breaks in the Time Series}

For 19 banks there were breaks in the time series. The years missing were reconstructed using the compound growth rate $^{23}$. In total 31 observations were reconstructed.

For a single bank 5 consecutive years were reconstructed, in two cases 3 years were reconstructed, in four cases 2 consecutive years and for the majority of cases (11) we reconstructed only one year.

Figure A-1: Breaks in the time series and number of observations that were reconstructed

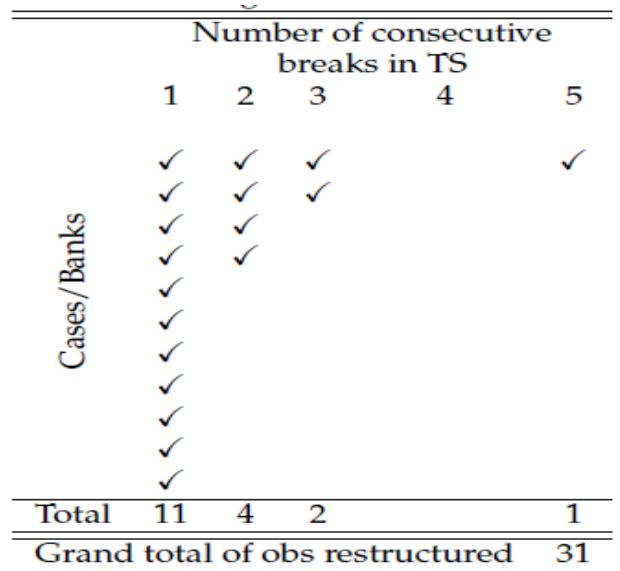

\section{A.5. Outliers}

After compiling the database and filling all missing values, several banks were exhibiting large growth rates of assets. We defined extreme growth rate an expansion or shrinking of assets larger than 20\%. Out of 3700 observations 1611 are identified as extreme and the problem concerns almost all banks in our database. Out of the 323 banks 310 exhibit an extreme growth of assets at least once over the whole time period.

The first check was examining if this could be attributed to the imputation process used. 80 banks have both imputed values and extreme growth of assets. We examined the cases one by one. We see that the extreme growth of assets doesn't concern the

23

$$
\text { Compound annual growth rate }=\frac{\text { Ending Value }}{\text { Beginning Value }}^{\frac{1}{\text { \#f years }}}-1
$$


time period for which data have been imputed and the problem spans over several other years.

Next we checked if the there was a general market trend of extreme growth in each country and our outliers are only riding the tide. 749 cases follow the general market trend.

Then we checked again for mergers or any other change of ownership. In 83 cases a bank of our sample acquired another bank and its growth rate is much above the market average. In 41 cases the major shareholder of a bank was altered which brought about a corporate restructuring and none of all the above scenarios apply. It is assumed that a corporate restructuring lasts at least three years, one year before the merger and a year after the event. In other 20 cases the major shareholder increased or decreased its percentage of shares which resulted to a bank changing also its status from domestic to foreign or vice versa.

Summing up 718 cases remain unexplained. The question that follows is whether those extreme values are attributed to measurement errors of the Bankscope and should be trimmed or depict actualized large deviations in the market. Bankscope provides assurances of data accuracy and having triple checked the data before their appearance on line (Andrianova, et al., 2015) ${ }^{24}$. Therefore we choose not to trim those data.

Observations were trimmed if

1. capital ratio is below 0 or over $100 \%$ or

2. liquidity ratio is below 0 or over $100 \%$ or

3. loan impairments to total loans is below $-100 \%$ or over $100 \%$ or

4. deposit ratio is below 0 or over $100 \%$ or

5. returns on assets are less than $-40 \%$ or

6. credit growth is below $-100 \%$

\footnotetext{
${ }^{24}$ Banks use some kind of automatic procedure and update directly to Fitch, who checks the entries. Bankscope receives the data from Fitch and checks again. Finally Bankscope checks the data a third time right before uploading them (Andrianova et al, 2015).
} 


\section{B. The Sample. Distribution of banks \& Aggregate Market shares}

Table B-1: Distribution of banks by Country, Year and type of ownership

\begin{tabular}{|c|c|c|c|c|c|c|c|c|c|c|c|c|c|c|}
\hline \multirow[b]{2}{*}{$\begin{array}{l}\text { Number } \\
\text { of banks }\end{array}$} & \multicolumn{14}{|c|}{ Year } \\
\hline & 2000 & 2001 & 2002 & 2003 & 2004 & 2005 & 2006 & 2007 & 2008 & 2009 & 2010 & 2011 & 2012 & 2013 \\
\hline \multicolumn{15}{|c|}{ Albania } \\
\hline Domestic & 2 & 2 & 2 & 3 & 2 & 2 & 1 & 2 & 2 & 2 & 2 & 3 & 3 & 2 \\
\hline Foreign & 2 & 2 & 3 & 4 & 6 & 6 & 8 & 8 & 8 & 9 & 9 & 8 & 8 & 9 \\
\hline \multicolumn{15}{|c|}{ Armenia } \\
\hline Domestic & & & 1 & 2 & 1 & 6 & 5 & 6 & 7 & 6 & 6 & 6 & 6 & 6 \\
\hline Foreign & 5 & 6 & 12 & 15 & 14 & 15 & 15 & 14 & 13 & 13 & 13 & 13 & 13 & 13 \\
\hline \multicolumn{15}{|c|}{ Bosnia Herzegovina } \\
\hline Domestic & 9 & 9 & 10 & 8 & 8 & 5 & 5 & 6 & 7 & 7 & 8 & 8 & 8 & 7 \\
\hline Foreign & 5 & 6 & 12 & 15 & 14 & 15 & 15 & 14 & 13 & 13 & 13 & 13 & 13 & 13 \\
\hline \multicolumn{15}{|c|}{ Bulgaria } \\
\hline Domestic & 8 & 9 & 8 & 7 & 8 & 8 & 7 & 6 & 6 & 6 & 6 & 7 & 7 & 7 \\
\hline Foreign & 14 & 14 & 15 & 16 & 15 & 15 & 15 & 11 & 11 & 11 & 11 & 10 & 10 & 9 \\
\hline \multicolumn{15}{|c|}{ Czech Republic } \\
\hline Domestic & 4 & 3 & 1 & 1 & 1 & 1 & 1 & 1 & 1 & 1 & 1 & 1 & 1 & 1 \\
\hline Foreign & 17 & 17 & 18 & 18 & 18 & 17 & 18 & 17 & 16 & 16 & 15 & 16 & 16 & 16 \\
\hline \multicolumn{15}{|c|}{ Estonia } \\
\hline Domestic & 1 & 1 & 1 & 1 & 1 & 1 & 2 & 2 & 2 & 2 & 2 & 2 & 2 & 2 \\
\hline Foreign & 4 & 4 & 4 & 4 & 4 & 4 & 4 & 4 & 3 & 3 & 3 & 4 & 4 & 4 \\
\hline \multicolumn{15}{|c|}{ Croatia } \\
\hline Domestic & 6 & 5 & 6 & 4 & 4 & 4 & 3 & 3 & 3 & 3 & 3 & 3 & 3 & 3 \\
\hline Foreign & 13 & 14 & 12 & 11 & 9 & 9 & 10 & 10 & 10 & 9 & 9 & 9 & 8 & 8 \\
\hline \multicolumn{15}{|c|}{ Hungary } \\
\hline Domestic & 4 & 4 & 4 & 2 & 2 & 2 & 2 & 3 & 3 & 4 & 4 & 4 & 4 & 4 \\
\hline Foreign & 14 & 14 & 14 & 15 & 14 & 14 & 14 & 11 & 11 & 9 & 9 & 9 & 9 & 9 \\
\hline \multicolumn{15}{|c|}{ Kosovo } \\
\hline Domestic & & 1 & 1 & 1 & 1 & 3 & 3 & 2 & 1 & 1 & 1 & 1 & 1 & 1 \\
\hline Foreign & & & 1 & 1 & 1 & 1 & 1 & 2 & 2 & 4 & 4 & 4 & 4 & 4 \\
\hline \multicolumn{15}{|c|}{ Lithuania } \\
\hline Domestic & 6 & 5 & 4 & 4 & 4 & 4 & 4 & 4 & 4 & 4 & 4 & 3 & 2 & 2 \\
\hline Foreign & 3 & 4 & 5 & 5 & 5 & 5 & 5 & 5 & 5 & 5 & 5 & 5 & 5 & 5 \\
\hline \multicolumn{15}{|c|}{ Latvia } \\
\hline Domestic & 11 & 12 & 12 & 13 & 13 & 14 & 11 & 9 & 8 & 7 & 7 & 7 & 8 & 7 \\
\hline Foreign & 6 & 7 & 7 & 7 & 7 & 6 & 8 & 10 & 10 & 10 & 11 & 10 & 9 & 10 \\
\hline \multicolumn{15}{|c|}{ Montenegro } \\
\hline Domestic & 1 & 1 & 3 & 4 & 5 & 5 & 2 & 2 & 2 & 2 & 2 & 2 & 2 & 2 \\
\hline Foreign & & 1 & 1 & 1 & 2 & 3 & 6 & 6 & 5 & 5 & 5 & 5 & 5 & 5 \\
\hline \multicolumn{15}{|c|}{ FYROM } \\
\hline Domestic & 6 & 8 & 8 & 8 & 7 & 6 & 8 & 5 & 4 & 4 & 4 & 4 & 4 & 4 \\
\hline Foreign & 3 & 3 & 3 & 3 & 5 & 5 & 5 & 8 & 9 & 8 & 7 & 8 & 8 & 8 \\
\hline
\end{tabular}

(The table continues on the next page) 
(Table B-1 continued from previous page)

\begin{tabular}{|c|c|c|c|c|c|c|c|c|c|c|c|c|c|c|}
\hline \multicolumn{15}{|c|}{ Poland } \\
\hline Domestic & 6 & 6 & 6 & 6 & 6 & 5 & 7 & 7 & 7 & 7 & 6 & 6 & 5 & 5 \\
\hline Foreign & 11 & 13 & 13 & 14 & 15 & 17 & 17 & 17 & 19 & 19 & 19 & 19 & 19 & 17 \\
\hline \multicolumn{15}{|c|}{ Romania } \\
\hline Domestic & 7 & 7 & 6 & 5 & 5 & 4 & 4 & 4 & 4 & 4 & 4 & 4 & 3 & 3 \\
\hline Foreign & 13 & 13 & 13 & 14 & 14 & 15 & 14 & 14 & 14 & 13 & 14 & 14 & 13 & 13 \\
\hline \multicolumn{15}{|c|}{ Serbia } \\
\hline Domestic & 13 & 18 & 22 & 21 & 21 & 15 & 12 & 10 & 11 & 11 & 11 & 9 & 7 & 6 \\
\hline Foreign & & 3 & 4 & 9 & 10 & 14 & 17 & 17 & 16 & 16 & 16 & 17 & 17 & 17 \\
\hline \multicolumn{15}{|c|}{ Slovenia } \\
\hline Domestic & 11 & 11 & 11 & 11 & 11 & 12 & 12 & 12 & 12 & 12 & 12 & 12 & 12 & 12 \\
\hline Foreign & 3 & 4 & 4 & 4 & 4 & 5 & 5 & 5 & 5 & 6 & 6 & 6 & 5 & 5 \\
\hline \multicolumn{15}{|c|}{ Slovak Republic } \\
\hline Domestic & 4 & 2 & 1 & 1 & 1 & 1 & 1 & 1 & 1 & 1 & 1 & 1 & 1 & 1 \\
\hline Foreign & 9 & 11 & 12 & 12 & 12 & 14 & 12 & 12 & 12 & 11 & 11 & 11 & 10 & 9 \\
\hline
\end{tabular}


Figure B-1: Aggregate market shares of foreign banks by country and year
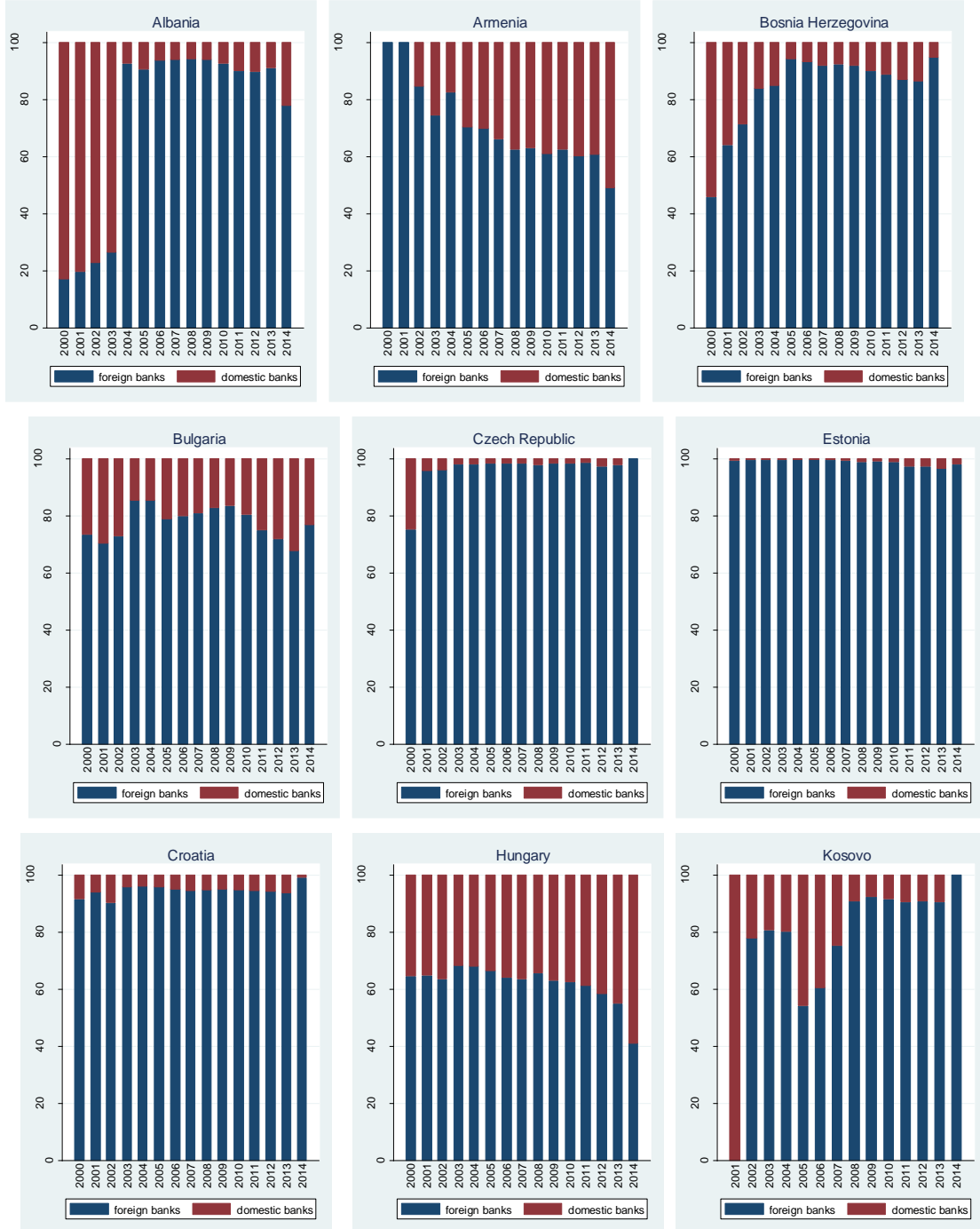

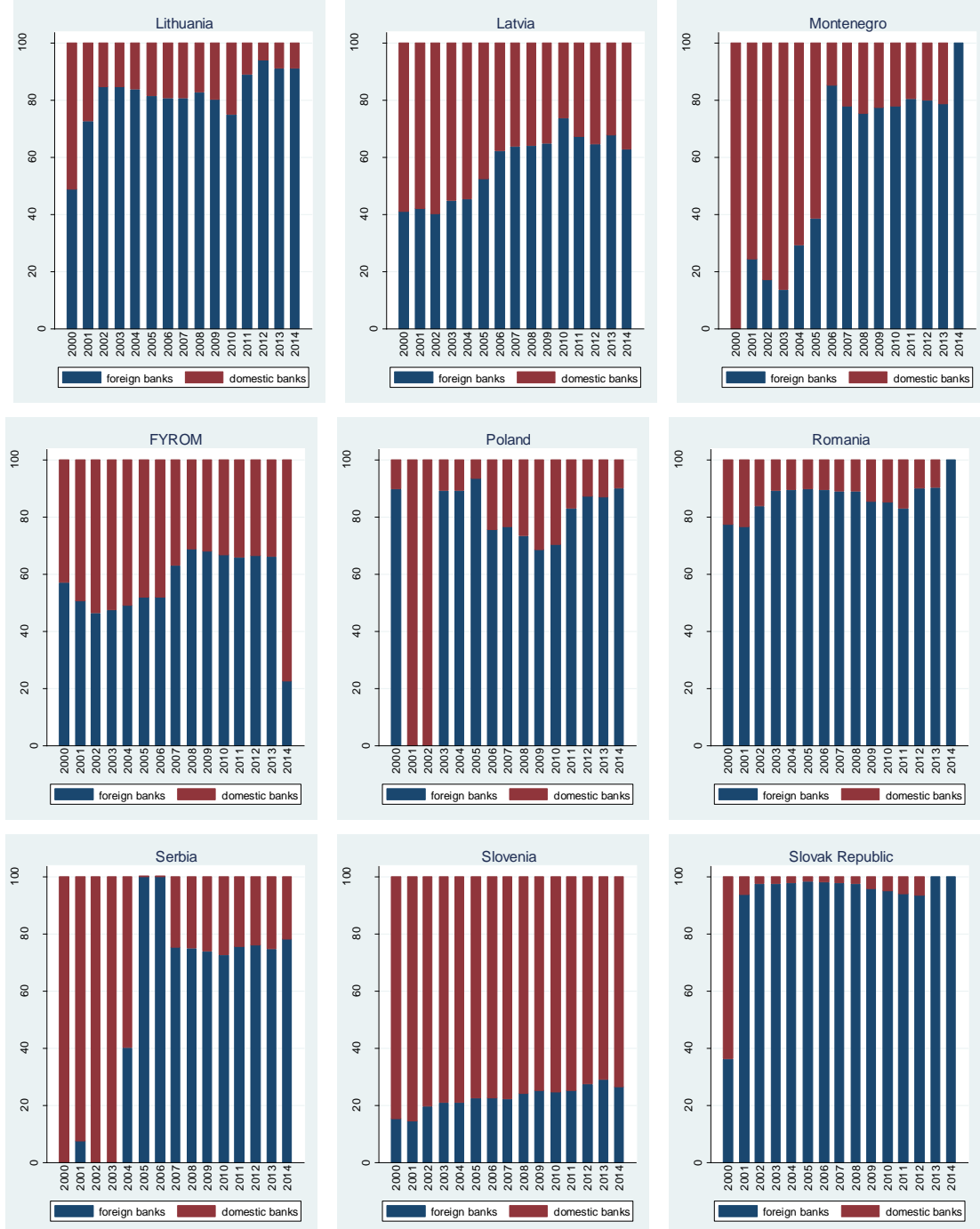
Figure B-2: Market share weighted aggregate credit growth of foreign banks vs domestic banks by country and year

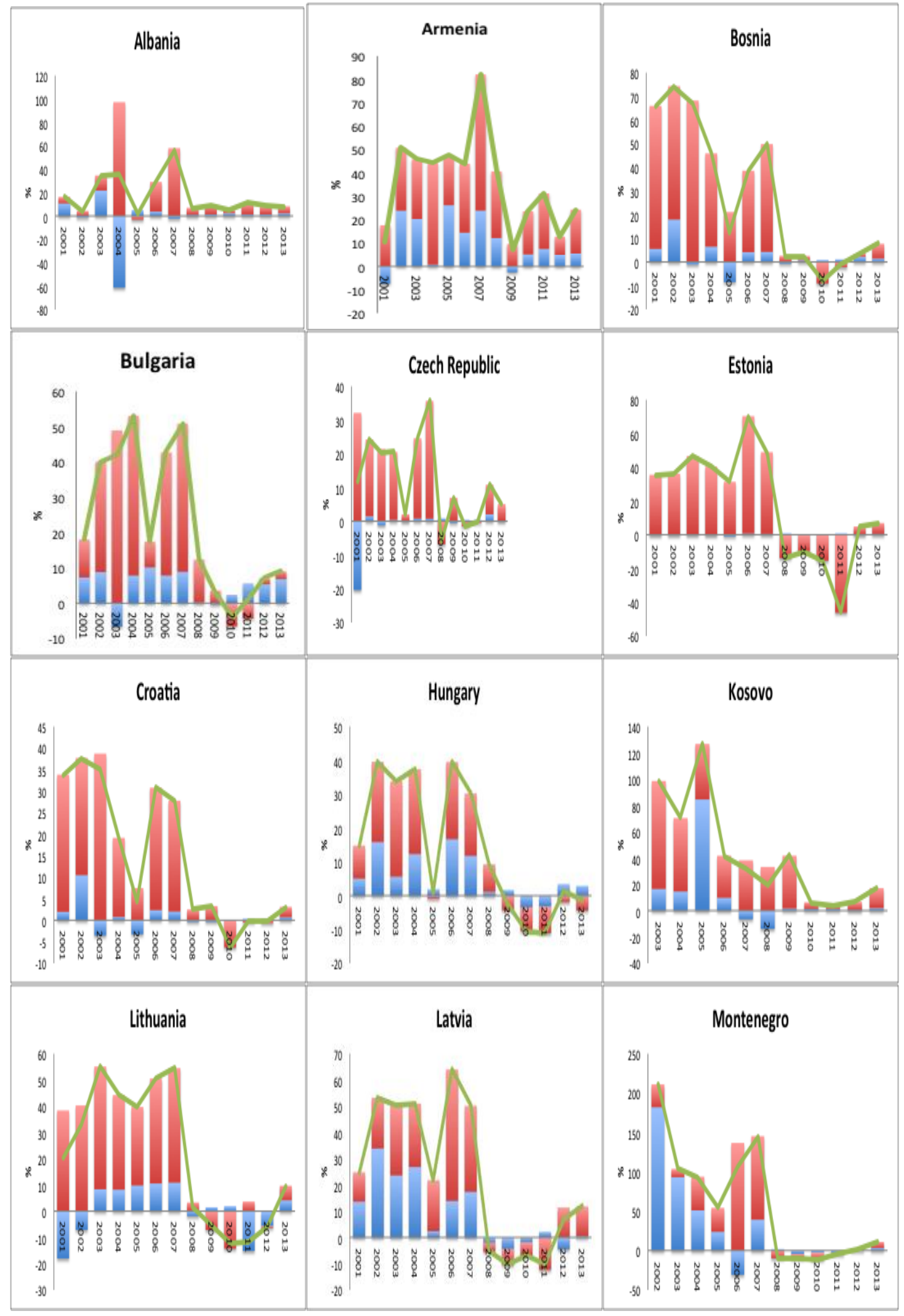




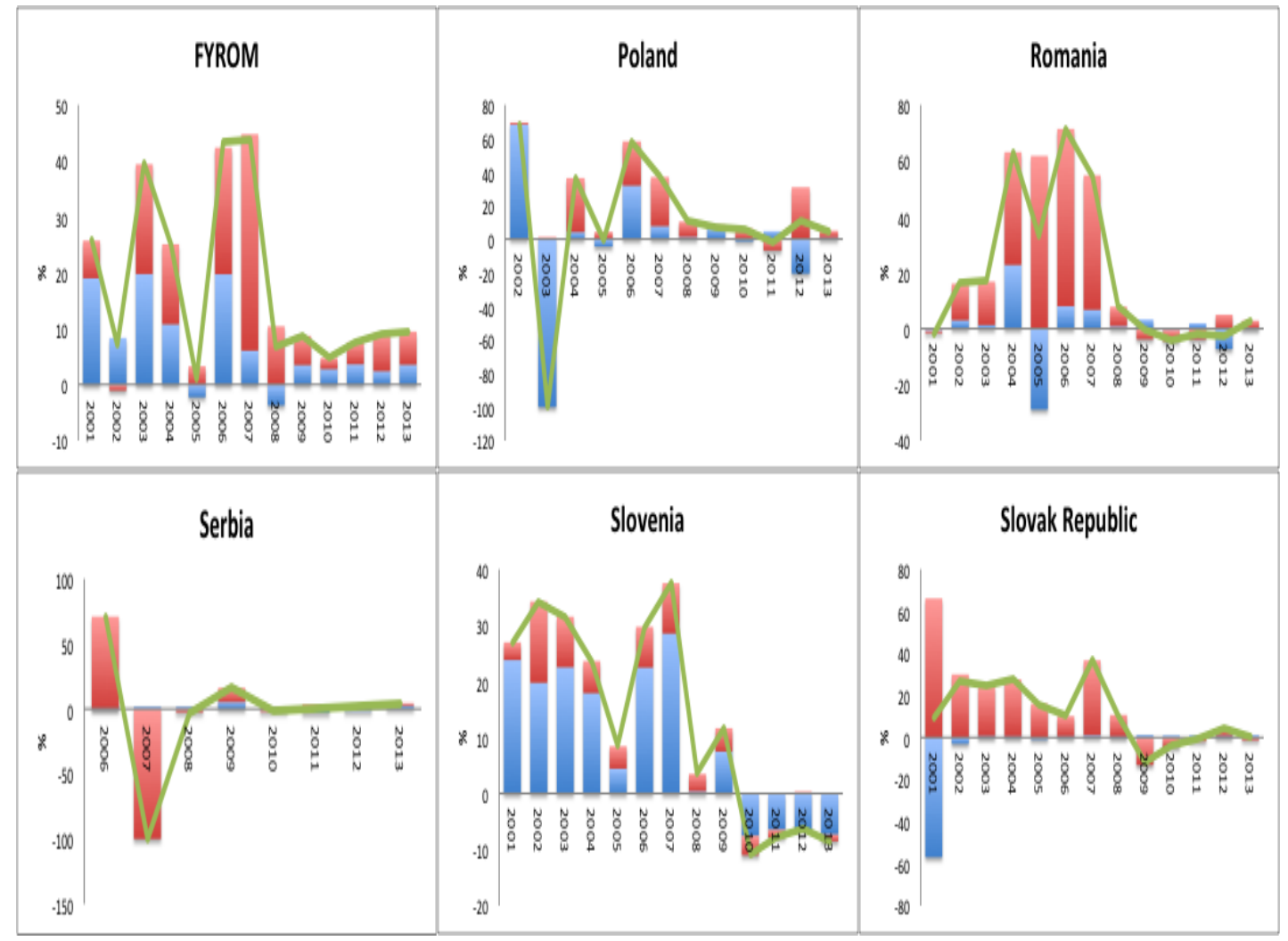

Foreign Banks

Domestic Banks

Overall growth 
Table B-2: Financial groups with subsidiaries operating in CESEE in 2000-2014

\begin{tabular}{|c|c|c|}
\hline Financial Group & $\begin{array}{l}\text { Home } \\
\text { Country }\end{array}$ & Host Country \\
\hline Volksbanken Holding regGenmbH & AT & 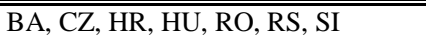 \\
\hline Raiffeisen & AT & $\begin{array}{l}\text { AL, BA, BG, CZ, HR, HU, KV, PL, } \\
\text { RO, RS, SI, SK }\end{array}$ \\
\hline BAWAG P.S.K. AG & AT & CZ, SI, SK \\
\hline Steiermarkische Bank und Sparkassen AG-Bank Styria & AT & BA, MK \\
\hline Oesterreichische Volksbanken AG & AT & BA, CZ, HR, HU, RO \\
\hline $\begin{array}{l}\text { Heta Asset Resolution AG - Former Hypo Alpe-Adria Bank } \\
\text { International AG }\end{array}$ & AT & BA, HR, ME, RS, SI \\
\hline Erste Group Bank AG & AT & $\mathrm{CZ}, \mathrm{HR}, \mathrm{HU}, \mathrm{RO}, \mathrm{RS}, \mathrm{SK}$ \\
\hline Creditanstalt AG & AT & SI \\
\hline BNP Paribas Fortis SA/ NV & $\mathrm{BE}$ & RO \\
\hline KBC Groep NV/ KBC Groupe SA-KBC Group & $\mathrm{BE}$ & CZ, HU, PL, RS, SK \\
\hline Dexia SA & $\mathrm{BE}$ & SK \\
\hline Central Cooperative Bank AD & BG & MK \\
\hline Cyprus Popular Bank Public Co Ltd & $\mathrm{CY}$ & RS \\
\hline Bayerische Landesbank & DE & $\mathrm{CZ}, \mathrm{HR}, \mathrm{HU}$ \\
\hline Commerzbank AG & $\mathrm{DE}$ & HU, PL \\
\hline Deutsche Bank AG & DE & CZ, PL \\
\hline Dresdner Bank AG & $\mathrm{DE}$ & $\mathrm{CZ}$ \\
\hline LHB Aktiengesellschaft & DE & BA, RS \\
\hline Norddeutsche Landesbank Girozentrale NORD/LB & DE & LT, LV, PL \\
\hline Portigon AG & DE & HU \\
\hline Landesbank Berlin Holding AG-LBB Holding AG & $\mathrm{DE}$ & $\mathrm{CZ}$ \\
\hline DZ Bank AG-Deutsche Zentral-Genossenschaftsbank & $\mathrm{DE}$ & HU \\
\hline ProCredit Holding AG \& Co. KGaA & $\mathrm{DE}$ & $\mathrm{AM}$ \\
\hline $\begin{array}{l}\text { UniCredit Bank AG (Proforma)- former Bayerische Hypo-und } \\
\text { Vereinsbank AG }\end{array}$ & $\mathrm{DE}$ & $\begin{array}{l}\text { BA, BG, CZ, HR, HU, PL, RO, RS, } \\
\text { SI, SK }\end{array}$ \\
\hline Landesbank Baden-Wuerttemberg & $\mathrm{DE}$ & $\mathrm{CZ}$ \\
\hline Danske Bank A/S & DK & EE, LT, LV \\
\hline Banco Santander SA & ES & PL \\
\hline Sampo Plc & FI & EE, LT, LV \\
\hline SociÈtÈ GÈnÈrale SA & FR & $\begin{array}{l}\text { AL, BG, CZ, HR, ME, MK, PL, RO, } \\
\text { RS, SI, SK }\end{array}$ \\
\hline BNP Paribas SA & FR & BG, HU, KV, PL \\
\hline CrÈdit Agricole S.A. & FR & AL, CZ, HU, PL, RS, SK \\
\hline Le CrÈdit Lyonnais (LCL) SA & FR & HU, SK \\
\hline HSBC Holdings Plc & GB & $\mathrm{AM}$ \\
\hline Royal Bank of Scotland Group Plc (The) & GB & RO \\
\hline National Bank of Greece SA & GR & $\mathrm{AL}, \mathrm{BG}, \mathrm{MK}, \mathrm{RO}, \mathrm{RS}$ \\
\hline Emporiki Bank of Greece SA & GR & AL \\
\hline Alpha Bank AE & GR & $\mathrm{AL}, \mathrm{BG}, \mathrm{MK}, \mathrm{RO}, \mathrm{RS}$ \\
\hline Eurobank Ergasias SA & GR & $\mathrm{BG}, \mathrm{RO}, \mathrm{RS}$ \\
\hline Piraeus Bank SA & GR & $\mathrm{AL}, \mathrm{BG}, \mathrm{RO}, \mathrm{RS}$ \\
\hline Zagrebacka Banka dd & HR & BA \\
\hline MKB Bank Zrt & HU & BG \\
\hline OTP Bank Plc & $\mathrm{HU}$ & BG, HR, ME, RO, RS, SK \\
\hline Cassa di Risparmio di Firenze SpA-Banca CR Firenze SpA & IT & RO \\
\hline Banca Commerciale Italiana SpA, COMIT & IT & $\mathrm{HR}, \mathrm{HU}$ \\
\hline
\end{tabular}

(The table continues on the next page) 
(Table B-2 continued from previous page)

\begin{tabular}{|c|c|c|}
\hline Financial Group & $\begin{array}{l}\text { Home } \\
\text { Country }\end{array}$ & Host Country \\
\hline UniCredit SpA & IT & $\begin{array}{l}\text { BA, BG, CZ, HR, HU, PL, RO, RS, } \\
\text { SI, SK }\end{array}$ \\
\hline SANPAOLO IMI & IT & $\mathrm{HU}, \mathrm{RO}$ \\
\hline Intesa Sanpaolo & IT & AL, BA, HR, HU, RO, RS, SK \\
\hline Veneto Banca scpa & IT & $\mathrm{AL}$ \\
\hline CreditBank SAL & LB & $\mathrm{AM}$ \\
\hline Byblos Bank S.A.L. & LB & AM \\
\hline AB Bankas Snoras & LT & LV \\
\hline AS Reverta & LV & LT \\
\hline AS Citadele Banka & LV & LT \\
\hline Demir-Halk Bank (Nederland) N.V-DHB Bank & TR & MK \\
\hline $\begin{array}{l}\text { Cooperatieve Centrale Raiffeisen-Boerenleenbank B.A-Rabobank } \\
\text { Nederland }\end{array}$ & NL & PL \\
\hline ING Bank NV & NL & BGPL \\
\hline Credit Europe Bank N.V. & NL & RO \\
\hline PPF Group N.V. & NL & $\mathrm{CZ}$ \\
\hline DnB ASA & NO & EE, LT, LV, PL \\
\hline Banco Comercial PortuguÍs, SA-Millennium bcp & PT & PL \\
\hline Komercijalna Banka A.D. Beograd & RS & $\mathrm{BA}, \mathrm{ME}$ \\
\hline VTB Bank, an Open Joint-Stock Company (JSC) & RU & $\mathrm{AM}$ \\
\hline Sberbank of Russia OAO & RU & BA, CZ, HR, HU, RS, SI \\
\hline MDM Bank & RU & LV \\
\hline Gazprombank Open Joint-Stock Company & RU & $\mathrm{AM}$ \\
\hline Joint Stock Commercial Bank - Bank of Moscow & RU & EE, LV \\
\hline $\begin{array}{l}\text { SMP Bank, Limited Liability Company-Commercial bank Severniy } \\
\text { morskoy puts }\end{array}$ & RU & LV \\
\hline Swedbank AB & SE & EE, LT, LV \\
\hline Skandinaviska Enskilda Banken AB & SE & EE, LT, LV \\
\hline Nordea Bank AB (publ) & SE & PL \\
\hline NLB dd-Nova Ljubljanska Banka d.d. & SI & $\mathrm{BA}, \mathrm{KV}, \mathrm{ME}, \mathrm{MK}, \mathrm{RS}$ \\
\hline Nova Kreditna Banka Maribor d.d. & SI & RS \\
\hline Fiba Holding AS & TR & RO \\
\hline T.C. Ziraat Bankasi A.S. & TR & BA, MK \\
\hline Turkiye Halk Bankasi A.S. & TR & MK \\
\hline Turkiye Garanti Bankasi A.S. & TR & RO \\
\hline Finansbank A.S. & TR & RO \\
\hline Birlesik fon Bankasi AS & TR & $\mathrm{AL}$ \\
\hline Kentbank A.S. & TR & $\mathrm{AL}$ \\
\hline Public Joint Stock Company Commercial Bank "PrivatBank" & UA & LV \\
\hline Pivdennyi Joint-Stock Bank & UA & LV \\
\hline Ukrprombank LLC-Ukrainsky Promyslovy Bank LLC & UA & $\mathrm{AM}$ \\
\hline General Electric Capital Corporation-GE Capital & US & CZ, HU, PL \\
\hline Citigroup Inc & US & $\mathrm{CZ}, \mathrm{HU}, \mathrm{PL}, \mathrm{RO}, \mathrm{SK}$ \\
\hline
\end{tabular}

Notes: The codes denote countries as below: $\mathrm{AL}=$ Albania, $\mathrm{AM}=$ Armenia, $\mathrm{AT}=$ Austria, $\mathrm{BE}=\mathrm{Belgium}, \mathrm{BA}=$ Bosnia and Herzegovina, $\mathrm{BG}=$ Bulgaria, $\mathrm{CZ}=$ Czech Republic, $\mathrm{DE}=$ Germany, $\mathrm{DK}=$ Denmark, $\mathrm{CY}=\mathrm{Cyprus}$, $\mathrm{EE}=$ Estonia, $\mathrm{ES}=$ Spain, FI $=$ Finland, FR $=$ France, $\mathrm{GB}=\mathrm{UK}, \mathrm{GE}=$ Georgia, GR $=$ Greece, HR $=$ Croatia, HU $=$ Hungary, $\mathrm{IT}=$ Italy, $\mathrm{KV}=$ Kosovo, $\mathrm{LB}=$ Lebanon, $\mathrm{LT}=$ Lithuania, $\mathrm{LV}=\mathrm{Latvia}, \mathrm{ME}=$ Montenegro, $\mathrm{MK}=$ FYROM, NL $=$ Netherland, $\mathrm{NO}=$ Norway, $\mathrm{PL}=$ Poland, $\mathrm{PT}=$ Portugal, $\mathrm{RO}=$ Romania, $\mathrm{RS}=$ Serbia, $\mathrm{RU}=$ Russia, $\mathrm{SE}=$ Sweden, $\mathrm{SK}=$ Slovakia, $\mathrm{SI}=$ Slovenia, $\mathrm{TR}=$ Turkey, UA $=$ Ukraine, US $=$ United States 


\section{Variable Descriptions \& Sources, Correlation Tables and Structure of our Ownership data}

Table C-1: Description and sources of the variables

\begin{tabular}{|c|c|c|c|}
\hline \multicolumn{4}{|c|}{ Variables } \\
\hline Indicator & Measure & Unite & Source \\
\hline Credit Growth & $\begin{array}{l}\text { The first difference of the } \\
\text { natural logarithm of loans } \\
\text { multiplied by } 100\end{array}$ & $\begin{array}{l}\% \text {, Initial values in } \\
\text { th USD }\end{array}$ & Bankscope \\
\hline $\begin{array}{l}\text { Economic Capital, both at } \\
\text { subsidiary \& parent level }\end{array}$ & Equity to total assets & $\begin{array}{l}\% \text {, Initial values in } \\
\text { th USD }\end{array}$ & Bankscope \\
\hline $\begin{array}{l}\text { Liquidity, both at subsidiary } \\
\& \text { parent level }\end{array}$ & Liquid assets to total assets & $\begin{array}{l}\% \text {, Initial values in } \\
\text { th USD }\end{array}$ & Bankscope \\
\hline Size & $\begin{array}{l}\text { The natural logarithm of total } \\
\text { assets }\end{array}$ & $\begin{array}{l}\text { Logarithm, initial } \\
\text { values in th USD }\end{array}$ & Bankscope \\
\hline $\begin{array}{l}\text { Profitability, both at } \\
\text { subsidiary \& parent level }\end{array}$ & Return to total assets & $\begin{array}{l}\% \text {, Initial values in } \\
\text { th USD }\end{array}$ & Bankscope \\
\hline Deposit ratio & $\begin{array}{l}\text { Customer deposits to total } \\
\text { funding }\end{array}$ & $\begin{array}{l}\% \text {, Initial values in } \\
\text { th USD }\end{array}$ & Bankscope \\
\hline $\begin{array}{l}\text { Loan Impairments, both at } \\
\text { subsidiary \& parent level }\end{array}$ & $\begin{array}{l}\text { Loan impairment charges to } \\
\text { total loans }\end{array}$ & $\begin{array}{l}\% \text {, Initial values in } \\
\text { th USD }\end{array}$ & Bankscope \\
\hline $\begin{array}{l}\text { Real GDP Growth, both in } \\
\text { the host and home country }\end{array}$ & $\begin{array}{l}\text { Host country's growth rate of } \\
\text { real GDP }\end{array}$ & 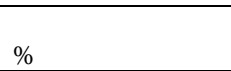 & National Sources, IMF and IHS \\
\hline $\begin{array}{l}\text { Inflation, both in the host } \\
\text { and home country }\end{array}$ & $\begin{array}{l}\text { Host country's Consumer price } \\
\text { index, year on year change }\end{array}$ & $\%$ & IHS \\
\hline Interest rate & $\begin{array}{l}\text { Host country's interest rate. For } \\
\text { all countries long term interest } \\
\text { rates were employed with the } \\
\text { exception of Armenia. In this } \\
\text { case the central bank policy rate } \\
\text { was used. }\end{array}$ & $\%$ & National Sources, IMF and IHS \\
\hline Global Financial Crisis & Equals 1 for the year 2008 & Dummy & \\
\hline Largest shareholder foreign & $\begin{array}{l}1 \text { if the largest shareholder is of } \\
\text { foreign origin no matter the } \\
\text { percentage it holds }\end{array}$ & Dummy & $\begin{array}{l}\text { In-house constructed ownership } \\
\text { database }\end{array}$ \\
\hline Foreign bank & $\begin{array}{l}1 \text { if the largest shareholder is } \\
\text { foreign and holds over } 49.9 \% \text { of } \\
\text { shares }\end{array}$ & Dummy & $\begin{array}{l}\text { In-house constructed ownership } \\
\text { database }\end{array}$ \\
\hline $\begin{array}{l}\text { Member of a foreign } \\
\text { financial group }\end{array}$ & $\begin{array}{l}1 \text { if the major shareholder is a } \\
\text { financial group holding over } \\
49.9 \% \text { of shares }\end{array}$ & Dummy & $\begin{array}{l}\text { In-house constructed ownership } \\
\text { database }\end{array}$ \\
\hline
\end{tabular}


Table C-2: Correlations of the variables calculated for the whole sample

\begin{tabular}{|c|c|c|c|c|c|c|c|c|c|c|}
\hline Variables & $\begin{array}{l}\text { Credit } \\
\text { growth }\end{array}$ & $\begin{array}{c}\text { Economic } \\
\text { Capital }\end{array}$ & $\begin{array}{l}\text { Liquidity } \\
\text { Liquidity }\end{array}$ & Size & $\begin{array}{l}\text { Profitability } \\
\text { Profitability }\end{array}$ & $\begin{array}{l}\text { Deposit } \\
\text { rate }\end{array}$ & $\begin{array}{c}\text { Loan } \\
\text { Impairments }\end{array}$ & $\begin{array}{c}\text { GDP } \\
\text { growth }\end{array}$ & $\begin{array}{c}\text { Inflation } \\
\text { rate }\end{array}$ & $\begin{array}{c}\text { Interesi } \\
\text { rate }\end{array}$ \\
\hline Credit growth & 1.000 & & & & & & & & & \\
\hline Economic Capital & $\begin{array}{c}0.066 \\
(0.000)\end{array}$ & 1.000 & & & & & & & & \\
\hline Liquidity & $\begin{array}{c}0.211 \\
(0.000)\end{array}$ & $\begin{array}{c}0.130 \\
(0.000)\end{array}$ & 1.000 & & & & & & & \\
\hline Size & $\begin{array}{l}-0.227 \\
(0.000)\end{array}$ & $\begin{array}{l}-0.499 \\
(0.000)\end{array}$ & $\begin{array}{l}-0.398 \\
(0.000)\end{array}$ & 1.000 & & & & & & \\
\hline Profitability & $\begin{array}{c}0.181 \\
(0.000)\end{array}$ & $\begin{array}{c}0.152 \\
(0.000)\end{array}$ & $\begin{array}{c}0.093 \\
(0.000)\end{array}$ & $\begin{array}{l}-0.005 \\
(0.759)\end{array}$ & 1.000 & & & & & \\
\hline Deposit rate & $\begin{array}{c}0.013 \\
(0.455)\end{array}$ & $\begin{array}{c}0.125 \\
(0.000)\end{array}$ & $\begin{array}{c}0.231 \\
(0.000)\end{array}$ & $\begin{array}{l}-0.114 \\
(0.000)\end{array}$ & $\begin{array}{c}0.068 \\
(0.000)\end{array}$ & 1.000 & & & & \\
\hline Loan & & & & & & & & & & \\
\hline Impairments & $\begin{array}{c}0.042 \\
(0.020)\end{array}$ & $\begin{array}{c}0.052 \\
(0.002)\end{array}$ & $\begin{array}{c}0.100 \\
(0.000)\end{array}$ & $\begin{array}{l}-0.136 \\
(0.000)\end{array}$ & $\begin{array}{l}-0.105 \\
(0.000)\end{array}$ & $\begin{array}{l}-0.013 \\
(0.465)\end{array}$ & 1.000 & & & \\
\hline GDP growth & $\begin{array}{c}0.349 \\
(0.000)\end{array}$ & $\begin{array}{c}0.070 \\
(0.000)\end{array}$ & $\begin{array}{c}0.239 \\
(0.000)\end{array}$ & $\begin{array}{l}-0.229 \\
(0.000)\end{array}$ & $\begin{array}{c}0.189 \\
(0.000)\end{array}$ & $\begin{array}{c}0.056 \\
(0.001)\end{array}$ & $\begin{array}{c}0.030 \\
(0.085)\end{array}$ & 1.000 & & \\
\hline Inflation rate & $\begin{array}{c}0.098 \\
(0.000)\end{array}$ & $\begin{array}{c}0.149 \\
(0.000)\end{array}$ & $\begin{array}{c}0.171 \\
(0.000)\end{array}$ & $\begin{array}{l}-0.188 \\
(0.000)\end{array}$ & $\begin{array}{c}0.117 \\
(0.000)\end{array}$ & $\begin{array}{l}-0.006 \\
(0.726)\end{array}$ & $\begin{array}{c}0.117 \\
(0.000)\end{array}$ & $\begin{array}{c}0.111 \\
(0.000)\end{array}$ & 1.000 & \\
\hline Interest rate & $\begin{array}{c}0.081 \\
(0.000)\end{array}$ & $\begin{array}{c}0.246 \\
(0.000)\end{array}$ & $\begin{array}{c}0.262 \\
(0.000)\end{array}$ & $\begin{array}{c}-0.322 \\
(0.000)\end{array}$ & $\begin{array}{c}0.012 \\
(0.460)\end{array}$ & $\begin{array}{c}0.085 \\
(0.000)\end{array}$ & $\begin{array}{c}0.109 \\
(0.000)\end{array}$ & $\begin{array}{c}0.019 \\
(0.248)\end{array}$ & $\begin{array}{c}0.585 \\
(0.000)\end{array}$ & 1.000 \\
\hline
\end{tabular}


Table C-3: Correlations of the variables calculated only for the sub-sample of subsidiaries of foreign financial groups

\begin{tabular}{|c|c|c|c|c|c|c|c|c|c|c|c|c|c|c|c|c|}
\hline Variables & $\begin{array}{l}\text { Credit } \\
\text { growth }\end{array}$ & $\begin{array}{c}\text { Economic } \\
\text { Capital }\end{array}$ & Liquidity & Size & Profitability & $\begin{array}{c}\text { Deposit } \\
\text { rate }\end{array}$ & $\begin{array}{c}\text { Loan } \\
\text { Impairments }\end{array}$ & $\begin{array}{l}\text { GDP } \\
\text { growth }\end{array}$ & $\begin{array}{c}\begin{array}{c}\text { Inflation } \\
\text { rate }\end{array} \\
\end{array}$ & $\begin{array}{c}\begin{array}{c}\text { Interest } \\
\text { rate }\end{array} \\
\end{array}$ & $\begin{array}{c}\text { Parent: } \\
\text { Profitability }\end{array}$ & $\begin{array}{c}\text { Parent } \\
\text { Liquidity }\end{array}$ & $\begin{array}{c}\text { Parent: } \\
\text { Economic Capital }\end{array}$ & $\begin{array}{l}\text { Parent Loan } \\
\text { Impairments } \\
\end{array}$ & $\begin{array}{l}\text { Home country: } \\
\text { GDP growth }\end{array}$ & $\begin{array}{l}\text { Home country: } \\
\text { Inflation rate }\end{array}$ \\
\hline $\begin{array}{l}\text { Credit } \\
\text { growth }\end{array}$ & 1.000 & & & & & & & & & & & & & & & \\
\hline $\begin{array}{l}\text { Economic } \\
\text { Capital }\end{array}$ & $\begin{array}{l}-0.018 \\
(0.429)\end{array}$ & 1.000 & & & & & & & & & & & & & & \\
\hline Liquidity & $\begin{array}{l}0.248 \\
(0.000)\end{array}$ & $\begin{array}{l}0.072 \\
(0.001)\end{array}$ & 1.000 & & & & & & & & & & & & & \\
\hline Size & $\begin{array}{r}-0.257 \\
(0.000)\end{array}$ & $\begin{array}{l}-0.354 \\
(0.000)\end{array}$ & $\begin{array}{l}-0.362 \\
(0.000)\end{array}$ & 1.000 & & & & & & & & & & & & \\
\hline Profitability & $\begin{array}{c}0.203 \\
(0.000)\end{array}$ & $\begin{array}{l}0.089 \\
(0.000)\end{array}$ & $\begin{array}{l}0.098 \\
(0.000)\end{array}$ & $\begin{array}{l}0.132 \\
(0.000)\end{array}$ & 1.000 & & & & & & & & & & & \\
\hline $\begin{array}{l}\text { Deposit } \\
\text { rate }\end{array}$ & $\begin{array}{c}0.004 \\
(0.871)\end{array}$ & $\begin{array}{l}0.111 \\
(0.000)\end{array}$ & $\begin{array}{l}0.242 \\
(0.000)\end{array}$ & $\begin{array}{r}-0.028 \\
(0.205)\end{array}$ & $\begin{array}{l}0.150 \\
(0.000)\end{array}$ & 1.000 & & & & & & & & & & \\
\hline Loan & 0.027 & -0.027 & 0.050 & -0.089 & -0.054 & 0.003 & 1.000 & & & & & & & & & \\
\hline Impairments & $(0.241)$ & $(0.246)$ & $(0.028)$ & $(0.000)$ & $(0.017)$ & $(0.897)$ & & & & & & & & & & \\
\hline $\begin{array}{l}\text { GDP } \\
\text { growth }\end{array}$ & $\begin{array}{l}0.411 \\
(0.000)\end{array}$ & $\begin{array}{l}-0.050 \\
(0.023)\end{array}$ & $\begin{array}{l}0.246 \\
(0.000)\end{array}$ & $\begin{array}{l}-0.182 \\
(0.000)\end{array}$ & $\begin{array}{l}0.260 \\
(0.000)\end{array}$ & $\begin{array}{c}0.046 \\
(0.040)\end{array}$ & $\begin{array}{l}-0.001 \\
(0.979)\end{array}$ & 1.000 & & & & & & & & \\
\hline $\begin{array}{l}\text { Inflation } \\
\text { rate }\end{array}$ & $\begin{array}{l}0.176 \\
(0.000)\end{array}$ & $\begin{array}{l}0.093 \\
(0.000)\end{array}$ & $\begin{array}{l}0.204 \\
(0.000)\end{array}$ & $\begin{array}{l}-0.178 \\
(0.000)\end{array}$ & $\begin{array}{l}0.047 \\
(0.033)\end{array}$ & $\begin{array}{r}-0.020 \\
(0.376)\end{array}$ & $\begin{array}{l}0.025 \\
(0.269)\end{array}$ & $\begin{array}{l}0.112 \\
(0.000)\end{array}$ & 1.000 & & & & & & & \\
\hline $\begin{array}{l}\text { Interest } \\
\text { rate }\end{array}$ & $\begin{array}{l}0.135 \\
(0.000)\end{array}$ & $\begin{array}{l}0.194 \\
(0.000)\end{array}$ & $\begin{array}{l}0.266 \\
(0.000)\end{array}$ & $\begin{array}{l}-0.302 \\
(0.000)\end{array}$ & $\begin{array}{l}-0.002 \\
(0.923)\end{array}$ & $\begin{array}{c}0.039 \\
(0.081)\end{array}$ & $\begin{array}{l}0.038 \\
(0.996)\end{array}$ & $\begin{array}{l}-0.002 \\
(0.943)\end{array}$ & $\begin{array}{l}0.712 \\
(0.000)\end{array}$ & 1.000 & & & & & & \\
\hline Parent: & 0.221 & 0.034 & 0.137 & -0.091 & 0.184 & 0.071 & -0.009 & 0.194 & 0.031 & 0.017 & 1.000 & & & & & \\
\hline Profitability & $(0.000)$ & $(0.129)$ & $(0.000)$ & $(0.000)$ & $(0.000)$ & $(0.001)$ & $(0.692)$ & $(0.000)$ & $(0.167)$ & $(0.439)$ & & & & & & \\
\hline $\begin{array}{l}\text { Parent: } \\
\text { Liquidity }\end{array}$ & $\begin{array}{l}0.071 \\
(0.002)\end{array}$ & $\begin{array}{l}-0.019 \\
(0.388)\end{array}$ & $\begin{array}{c}0.276 \\
(0.000)\end{array}$ & $\begin{array}{l}-0.136 \\
(0.000)\end{array}$ & $\begin{array}{l}0.073 \\
(0.001)\end{array}$ & $\begin{array}{l}0.012 \\
(0.575)\end{array}$ & $\begin{array}{c}0.055 \\
(0.017)\end{array}$ & $\begin{array}{l}0.087 \\
(0.000)\end{array}$ & $\begin{array}{c}0.068 \\
(0.002)\end{array}$ & $\begin{array}{l}0.121 \\
(0.000)\end{array}$ & $\begin{array}{c}0.098 \\
(0.000)\end{array}$ & 1.000 & & & & \\
\hline $\begin{array}{l}\text { Parent: Economic } \\
\text { Capital }\end{array}$ & $\begin{array}{c}0.028 \\
(0.217)\end{array}$ & $\begin{array}{l}0.155 \\
(0.000)\end{array}$ & $\begin{array}{c}0.034 \\
(0.129)\end{array}$ & $\begin{array}{l}-0.143 \\
(0.000)\end{array}$ & $\begin{array}{l}-0.036 \\
(0.110)\end{array}$ & $\begin{array}{c}0.173 \\
(0.000)\end{array}$ & $\begin{array}{l}-0.040 \\
(0.082)\end{array}$ & $\begin{array}{l}-0.047 \\
(0.033)\end{array}$ & $\begin{array}{l}-0.052 \\
(0.018)\end{array}$ & $\begin{array}{r}-0.019 \\
(0.393)\end{array}$ & $\begin{array}{c}0.487 \\
(0.000)\end{array}$ & $\begin{array}{l}-0.124 \\
(0.000)\end{array}$ & 1.000 & & & \\
\hline $\begin{array}{l}\text { Parent Loan } \\
\text { Impairments }\end{array}$ & $\begin{array}{r}-0.201 \\
(0.000)\end{array}$ & $\begin{array}{c}0.081 \\
(0.000)\end{array}$ & $\begin{array}{l}-0.048 \\
(0.034)\end{array}$ & $\begin{array}{l}-0.048 \\
(0.031)\end{array}$ & $\begin{array}{l}-0.222 \\
(0.000)\end{array}$ & $\begin{array}{c}0.088 \\
(0.000)\end{array}$ & $\begin{array}{c}0.007 \\
(0.763)\end{array}$ & $\begin{array}{l}-0.290 \\
(0.000)\end{array}$ & $\begin{array}{l}-0.048 \\
(0.033)\end{array}$ & $\begin{array}{c}0.021 \\
(0.350)\end{array}$ & $\begin{array}{r}-0.411 \\
(0.000)\end{array}$ & $\begin{array}{r}-0.199 \\
(0.000)\end{array}$ & $\begin{array}{l}0.315 \\
(0.000)\end{array}$ & 1.000 & & \\
\hline $\begin{array}{l}\text { Home country: } \\
\text { GDP growth }\end{array}$ & 0.326 & $\begin{array}{l}0.042 \\
(0.057)\end{array}$ & $\begin{array}{l}0.262 \\
(0.000)\end{array}$ & $\begin{array}{l}-0.218 \\
-0.2000\end{array}$ & $\begin{array}{l}0.181 \\
(0,000)\end{array}$ & 0.030 & $\begin{array}{l}0.014 \\
(0.551)\end{array}$ & 0.586 & 0.101 & $\begin{array}{l}0.063 \\
(0.004)\end{array}$ & $\begin{array}{l}0.412 \\
(0,000)\end{array}$ & $\begin{array}{l}0.198 \\
(0,000)\end{array}$ & $\begin{array}{l}0.181 \\
(0,000)\end{array}$ & $\begin{array}{l}-0.315 \\
(0.000)\end{array}$ & 1.000 & \\
\hline $\begin{array}{l}\text { Home country: } \\
\text { Inflation rate }\end{array}$ & $\begin{array}{c}0.072 \\
(0.002)\end{array}$ & $\begin{array}{l}0.260 \\
(0.000)\end{array}$ & $\begin{array}{c}0.179 \\
(0.000)\end{array}$ & $\begin{array}{l}-0.315 \\
(0.000)\end{array}$ & $\begin{array}{c}0.019 \\
(0.401)\end{array}$ & $\begin{array}{c}0.097 \\
(0.000)\end{array}$ & $\begin{array}{c}0.009 \\
(0.678)\end{array}$ & $\begin{array}{c}0.0058 \\
(0.009)\end{array}$ & $\begin{array}{l}0.112 \\
(0.000)\end{array}$ & $\begin{array}{c}0.180 \\
(0.000)\end{array}$ & $\begin{array}{c}0.152 \\
(0.000)\end{array}$ & $\begin{array}{c}0.118 \\
(0.000)\end{array}$ & $\begin{array}{l}0.295 \\
(0.000)\end{array}$ & $\begin{array}{l}0.175 \\
(0.000)\end{array}$ & $\begin{array}{c}0.207 \\
(0.000)\end{array}$ & 1.000 \\
\hline
\end{tabular}


Figure C-1: Structure of the data

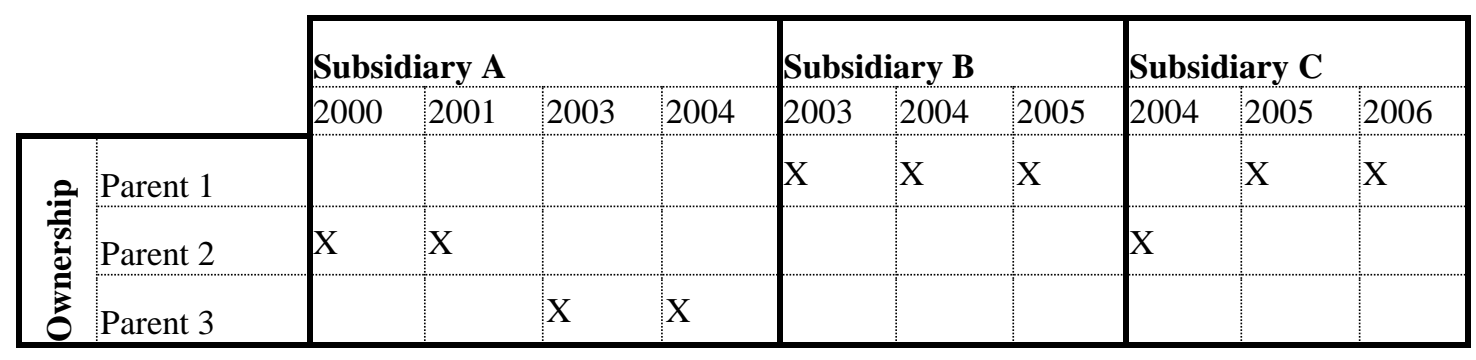




\section{Report of unabbreviated tables}

Table D-1: Loan growth of members of foreign financial groups vis-à-vis domestic banks before and after crisis

\begin{tabular}{|c|c|c|c|c|c|c|c|c|c|}
\hline \multirow{3}{*}{$\begin{array}{l}\text { Dependent variable: } \\
\text { Loan growth }\end{array}$} & \multicolumn{3}{|c|}{ Before the 2008 crisis (2000-2007) } & \multicolumn{3}{|c|}{ After the 2008 crisis (2008-2013) } & \multicolumn{3}{|c|}{$\begin{array}{l}\text { Pooled with pre-post crisis dummies interacted with } \\
\text { ownership }\end{array}$} \\
\hline & (1) & (2) & (3) & (4) & (5) & (6) & (7) & (8) & (9) \\
\hline & $\mathrm{FE}$ & sys GMM & diff GMM & fe & sys GMM & diff GMM & $\mathrm{FE}$ & sys GMM & diff GMM \\
\hline Loan growth (t-1) & $\begin{array}{c}0.080 * * \\
(0.039)\end{array}$ & $\begin{array}{c}0.330 * * * \\
(0.059)\end{array}$ & $\begin{array}{c}0.277 * * * \\
(0.085)\end{array}$ & $\begin{array}{l}0.066^{*} \\
(0.038)\end{array}$ & $\begin{array}{c}0.244 * * * \\
(0.056)\end{array}$ & $\begin{array}{r}0.079 * * \\
(0.031)\end{array}$ & $\begin{array}{c}0.119 * * * \\
(0.024)\end{array}$ & $\begin{array}{c}0.254 * * * \\
(0.038)\end{array}$ & $\begin{array}{c}0.142 * * * \\
(0.048)\end{array}$ \\
\hline Economic Capital (t-1) & $\begin{array}{l}0.275 \\
(0.334)\end{array}$ & $\begin{array}{c}0.135 \\
(0.273)\end{array}$ & $\begin{array}{c}0.179 \\
(0.334)\end{array}$ & $\begin{array}{l}0.257 \\
(0.278)\end{array}$ & $\begin{array}{c}0.137 \\
(0.253)\end{array}$ & $\begin{array}{l}0.325 \\
(0.498)\end{array}$ & $\begin{array}{c}0.358^{* *} \\
(0.159)\end{array}$ & $\begin{array}{c}0.020 \\
(0.205)\end{array}$ & $\begin{array}{c}0.681 \\
(0.434)\end{array}$ \\
\hline Liquidity (t-1) & $\begin{array}{c}0.928 * * * \\
(0.119)\end{array}$ & $\begin{array}{c}0.223 * * \\
(0.112)\end{array}$ & $\begin{array}{l}0.326^{* *} \\
(0.135)\end{array}$ & $\begin{array}{c}0.421 * * * \\
(0.074)\end{array}$ & $\begin{array}{c}0.244^{* *} \\
(0.100)\end{array}$ & $\begin{array}{c}0.427 * * * \\
(0.134)\end{array}$ & $\begin{array}{c}0.417 * * * \\
(0.054)\end{array}$ & $\begin{array}{c}0.114 \\
(0.086)\end{array}$ & $\begin{array}{c}0.464 * * * \\
(0.170)\end{array}$ \\
\hline Size $(\mathrm{t}-1)$ & $\begin{array}{l}-25.932 * * * \\
(3.809)\end{array}$ & $\begin{array}{l}-2.644 \\
(1.713)\end{array}$ & $\begin{array}{l}-9.600 \\
(6.792)\end{array}$ & $\begin{array}{l}-21.538 * * * \\
(3.858)\end{array}$ & $\begin{array}{l}-2.130 * * \\
(0.901)\end{array}$ & $\begin{array}{l}-19.332 * * \\
(9.398)\end{array}$ & $\begin{array}{l}-12.913 * * * \\
(1.622)\end{array}$ & $\begin{array}{l}-3.733 * * * \\
(0.968)\end{array}$ & $\begin{array}{l}-3.449 \\
(3.643)\end{array}$ \\
\hline Profitability (t-1) & $\begin{array}{l}0.891 * \\
(0.537)\end{array}$ & $\begin{array}{c}0.519 \\
(0.644)\end{array}$ & $\begin{array}{l}-0.207 \\
(0.907)\end{array}$ & $\begin{array}{l}0.913^{*} \\
(0.521)\end{array}$ & $\begin{array}{c}0.917 \\
(0.665)\end{array}$ & $\begin{array}{c}0.176 \\
(0.840)\end{array}$ & $\begin{array}{c}1.023 * * * \\
(0.367)\end{array}$ & $\begin{array}{l}1.306^{*} \\
(0.682)\end{array}$ & $\begin{array}{c}0.546 \\
(0.990)\end{array}$ \\
\hline Deposit rate $(\mathrm{t}-1)$ & $\begin{array}{l}-0.034 \\
(0.107)\end{array}$ & $\begin{array}{l}-0.065 \\
(0.095)\end{array}$ & $\begin{array}{l}-0.021 \\
(0.136)\end{array}$ & $\begin{array}{l}-0.024 \\
(0.068)\end{array}$ & $\begin{array}{l}0.111^{*} \\
(0.060)\end{array}$ & $\begin{array}{l}-0.056 \\
(0.163)\end{array}$ & $\begin{array}{l}-0.053 \\
(0.067)\end{array}$ & $\begin{array}{l}0.020 \\
(0.057)\end{array}$ & $\begin{array}{l}-0.021 \\
(0.134)\end{array}$ \\
\hline Loan Impairments (t-1) & $\begin{array}{l}-0.036 \\
(0.079)\end{array}$ & $\begin{array}{l}-0.060 \\
(0.068)\end{array}$ & $\begin{array}{l}-0.073 \\
(0.069)\end{array}$ & $\begin{array}{c}0.024 \\
(0.069)\end{array}$ & $\begin{array}{l}-0.069 \\
(0.112)\end{array}$ & $\begin{array}{l}-0.154 \\
(0.161)\end{array}$ & $\begin{array}{c}-0.136^{* * * *} \\
(0.042)\end{array}$ & $\begin{array}{c}-0.262 * * \\
(0.116)\end{array}$ & $\begin{array}{c}-0.736 * * * \\
(0.223)\end{array}$ \\
\hline GDP growth & $\begin{array}{c}1.718 * * * \\
(0.616)\end{array}$ & $\begin{array}{l}1.105 * * \\
(0.491)\end{array}$ & $\begin{array}{c}1.455 * * * \\
(0.475)\end{array}$ & $\begin{array}{c}0.774 * * * \\
(0.271)\end{array}$ & $\begin{array}{c}0.676 * * * \\
(0.221)\end{array}$ & $\begin{array}{c}0.757 * * * \\
(0.273)\end{array}$ & $\begin{array}{c}0.639 * * * \\
(0.147)\end{array}$ & $\begin{array}{c}0.560 * * * \\
(0.155)\end{array}$ & $\begin{array}{c}0.528 * * * \\
(0.179)\end{array}$ \\
\hline Inflation rate & $\begin{array}{l}-0.117 \\
(0.460)\end{array}$ & $\begin{array}{c}0.383 \\
(0.294)\end{array}$ & $\begin{array}{c}0.080 \\
(0.344)\end{array}$ & $\begin{array}{c}0.827 * * * \\
(0.277)\end{array}$ & $\begin{array}{c}0.420 \\
(0.283)\end{array}$ & $\begin{array}{c}0.605 * * \\
(0.277)\end{array}$ & $\begin{array}{c}0.608 * * * \\
(0.203)\end{array}$ & $\begin{array}{c}0.419 * * \\
(0.201)\end{array}$ & $\begin{array}{c}0.529 * * \\
(0.248)\end{array}$ \\
\hline Interest rate & $\begin{array}{c}-1.192 * * * \\
(0.439)\end{array}$ & $\begin{array}{l}-0.450 \\
(0.331)\end{array}$ & $\begin{array}{l}-0.208 \\
(0.399)\end{array}$ & $\begin{array}{c}0.166 \\
(0.377)\end{array}$ & $\begin{array}{l}-0.462^{*} \\
(0.255)\end{array}$ & $\begin{array}{c}0.183 \\
(0.409)\end{array}$ & $\begin{array}{c}-1.086^{* * *} \\
(0.256)\end{array}$ & $\begin{array}{c}-0.427 * * \\
(0.199)\end{array}$ & $\begin{array}{l}-0.515^{*} \\
(0.291)\end{array}$ \\
\hline member of a foreign financial group & $\begin{array}{c}24.278 * * * \\
(7.349)\end{array}$ & $\begin{array}{c}8.493 * * * \\
(2.548)\end{array}$ & $\begin{array}{c}11.824 * * * \\
(4.435)\end{array}$ & $\begin{array}{l}-0.219 \\
(9.083)\end{array}$ & $\begin{array}{c}2.374 \\
(1.691)\end{array}$ & $\begin{array}{l}-2.299 \\
(20.254)\end{array}$ & & & \\
\hline year $==2003$ & $\begin{array}{c}3.982 \\
(2.762)\end{array}$ & $\begin{array}{c}17.231 * * * \\
(3.569)\end{array}$ & $\begin{array}{c}5.464 \\
(8.186)\end{array}$ & & & & & & \\
\hline year $==2004$ & $\begin{array}{c}9.093 * * \\
(3.876)\end{array}$ & $\begin{array}{c}11.735 * * * \\
(3.273)\end{array}$ & $\begin{array}{c}3.171 \\
(6.653)\end{array}$ & & & & & & \\
\hline year $==2005$ & $\begin{array}{c}0.396 \\
(5.203)\end{array}$ & $\begin{array}{l}-3.682 \\
(2.985)\end{array}$ & $\begin{array}{c}-11.543^{* *} \\
(4.931)\end{array}$ & & & & & & \\
\hline year $==2006$ & $\begin{array}{c}28.170 * * * \\
(5.630)\end{array}$ & $\begin{array}{c}26.497 * * * \\
(3.007)\end{array}$ & $\begin{array}{c}19.783 * * * * \\
(5.202)\end{array}$ & & & & & & \\
\hline year $==2007$ & $\begin{array}{c}43.203 * * * \\
(6.671)\end{array}$ & $\begin{array}{c}24.610^{* * * *} \\
(3.393)\end{array}$ & $\begin{array}{c}21.646 * * * \\
(3.594)\end{array}$ & & & & & & \\
\hline
\end{tabular}


Table D- 1 continued from previous page

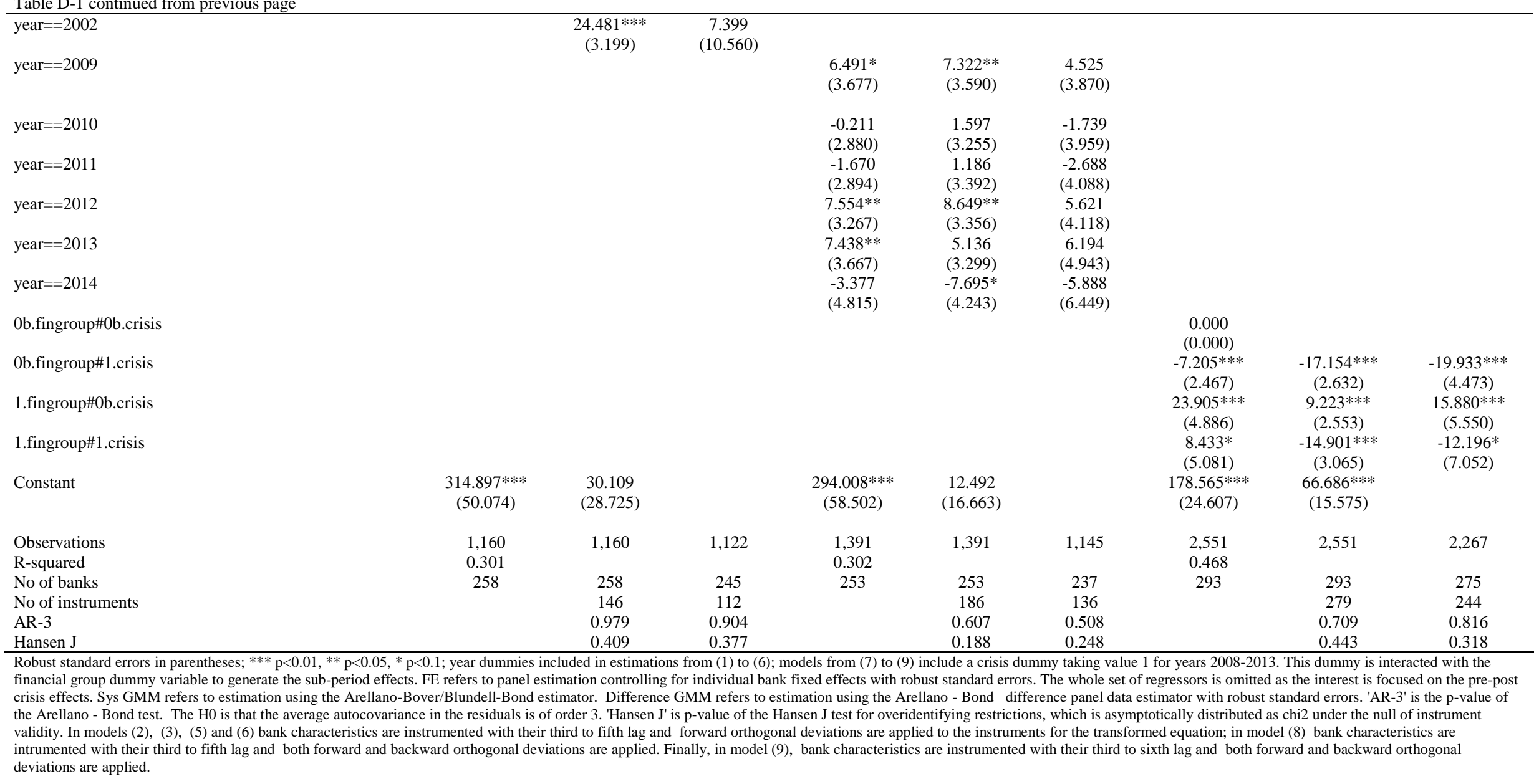

